\author{
ZENTRUM \\ FÜR BIODIVERSITÄT UND NACHHALTIGE LANDNUTZUNG \\ SEKTION \\ BIODIVERSITÄT, ÖKOLOGIE UND NATURSCHUTZ \\ - Centre of Biodiversity and Sustainable Land USe - \\ Section: Biodiversity, Ecology and Nature Conservation
}

\title{
Carbon flow in belowground food webs assessed by isotope tracers
}

\author{
Dissertation zur Erlangung des Doktorgrades der \\ Mathematisch-Naturwissenschaftlichen Fakultäten der \\ Georg-August-Universität Göttingen
}

vorgelegt von

Diplom-Biologin

Nicole Scheunemann

aus

Zossen

Göttingen, Februar 2015 
Referent: Prof. Dr. Stefan Scheu

Korreferent: Prof. Dr. Ulrich Brose

Tag der mündlichen Prüfung: 20.03.2015 
The main use of isotopes involves magic.

Brian Fry 


\section{Table of contents}

SUMMARY

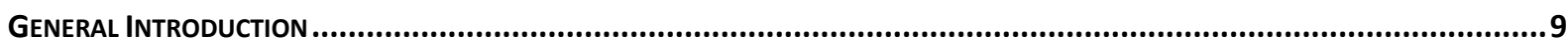

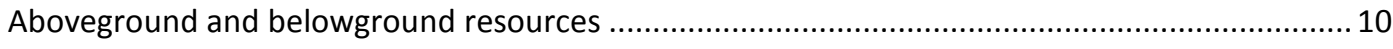



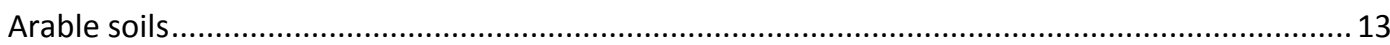

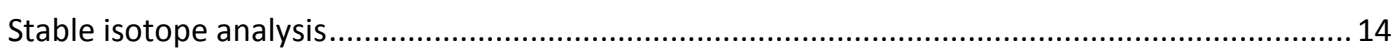

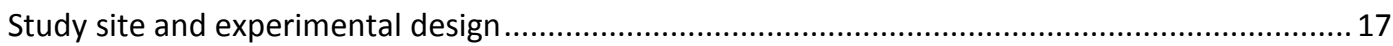

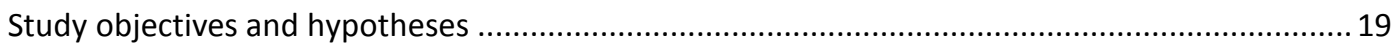



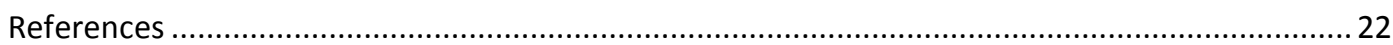

The Role of Shoot Residues vs. Crop Species for SOIL Arthropod Diversity and Abundance of Arable SyStems ........ 31



Roots Rather than Shoot Residues Drive Soll Arthropod Communities of Arable Fields ......................................64

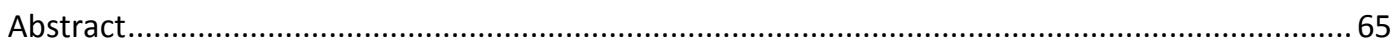

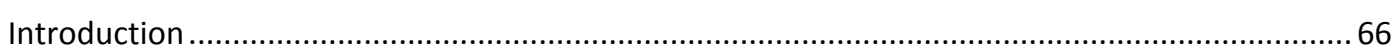

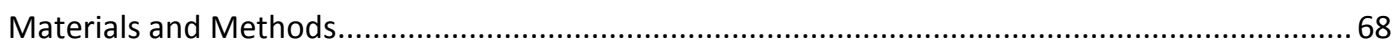


Study site 68

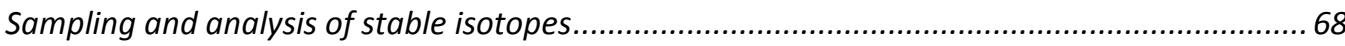

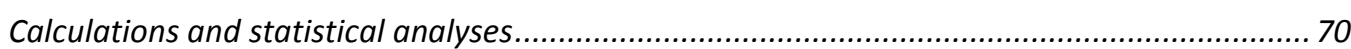

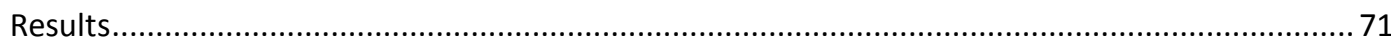

Changes in incorporation of root-derived maize $C$ with time .............................................. 71

Incorporation of shoot residue- vs. root-derived C ..................................................... 73



Changes in incorporation of root-derived maize $\mathrm{C}$ with time .................................................... 76

Incorporation of shoot residue- and root-derived $C$............................................................. 77

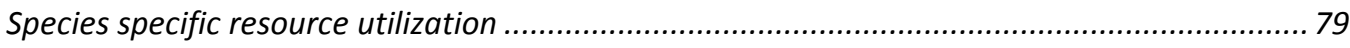

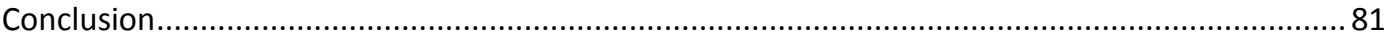



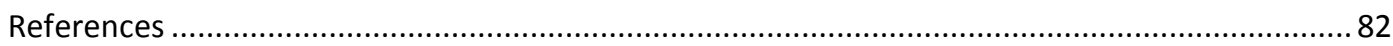

InCORPORATION Of RoOt C ANd Fertilizer N INTO the Food Web Of AN ARABle Field:.............................................89



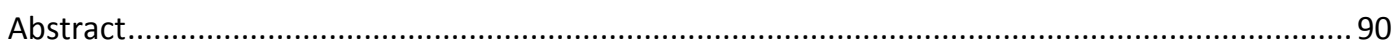

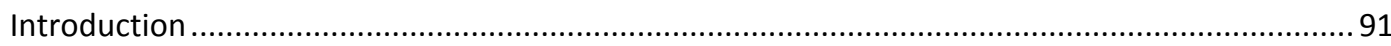

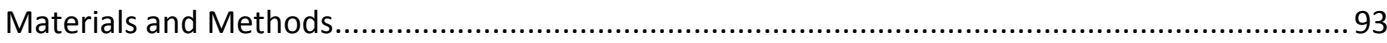

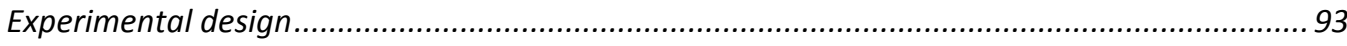

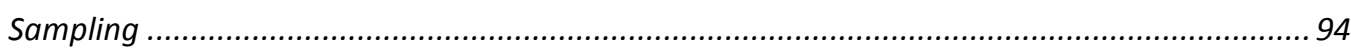

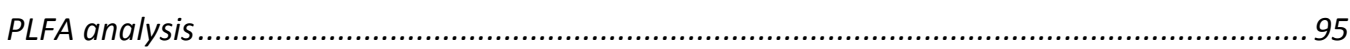

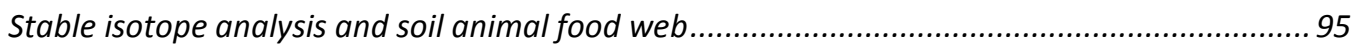



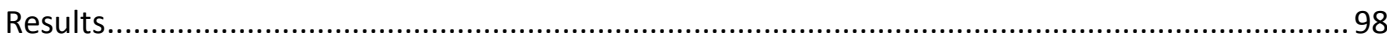

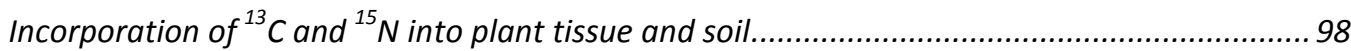



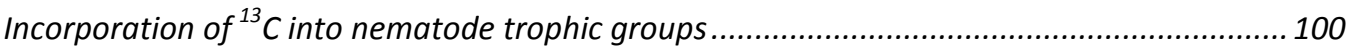

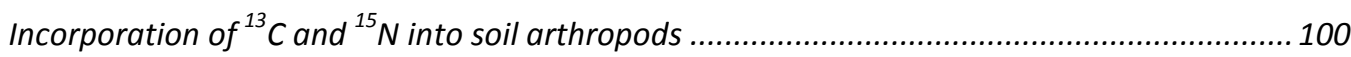

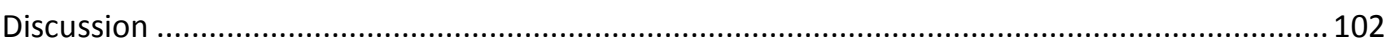

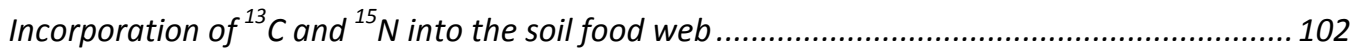

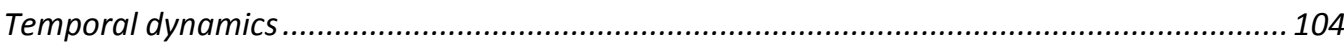

Extent of ${ }^{13} \mathrm{C}$ enrichment in different trophic levels ........................................................... 105



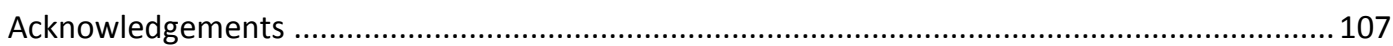

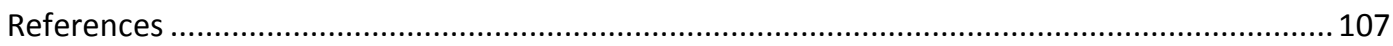

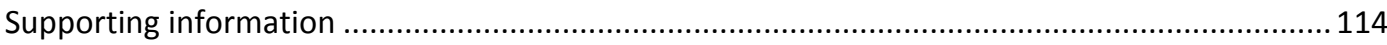


The role of shoot residue- and root-derived C for arable soil food webs...................................... 118

Feeding strategies of trophic and taxonomic groups and individual species ................................ 120

Habitat conditions in maize and wheat fields........................................................................ 121

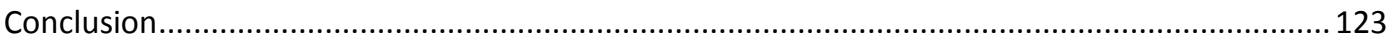

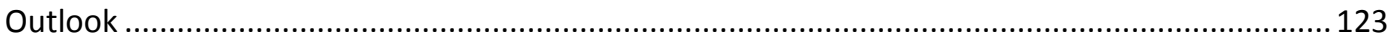

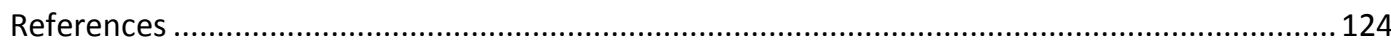



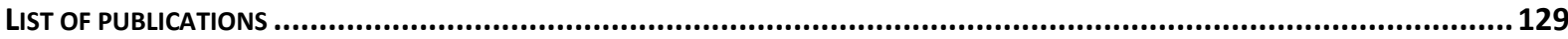

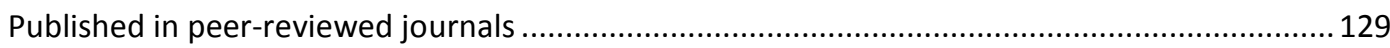

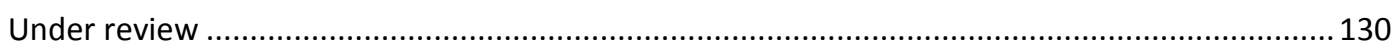



Declaration of the author's own contribution to manuscripts with multiple authors ................... 131

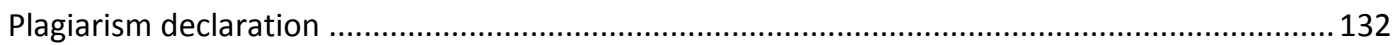




\section{Summary}

Soil food webs are complex networks that consist of several trophic levels and taxonomic groups including soil microorganisms, protists, nematodes, annelids and soil arthropods. Interactions between and within trophic levels and taxonomic groups regulate important ecosystem functions such as the cycling of carbon (C) and nutrients, with soil microorganisms channeling resources from the base of the food web to higher trophic levels of meso- and macrofauna decomposers and predators. Root exudates and decomposing plant residues are the major basal resources of $C$, and recent research highlighted the dominant role of root $\mathrm{C}$ for forest soil food webs. However, despite the large importance of agroecosystems for the global energy budget, channeling of $\mathrm{C}$ and nutrients in arable systems still is little understood. The present thesis focused on the flux of shoot residue- and root-derived $C$ within arable soil food webs. In three field experiments I investigated soil animal community responses and the incorporation of shoot residue- and root-derived $\mathrm{C}$ into soil meso- and macrofauna at the species level.

In the experiment presented in Chapter $2 \mathrm{I}$ investigated the effects of aboveground resources on abundances and community composition of the soil animal food web of two arable fields planted with wheat and maize, respectively, by adding hackled maize shoot residues to the fields. Addition of shoot residue-derived resources did not affect the soil animal food web, suggesting that aboveground resources are of minor importance for soil animal communities. However, independent of shoot residue addition, the abundance and diversity were much higher and more fluctuating in wheat as compared to maize fields, due to more favourable habitat conditions and more pronounced pulses of rootderived resources in form of root exudates and decomposing root residues in wheat.

Taking advantage of the differences in natural ${ }^{13} \mathrm{C} /{ }^{12} \mathrm{C}$ signatures of wheat and maize I tracked the incorporation of shoot residue- and root-derived resources into the body tissue of soil animals (Chapter 3). In general, one year after the start of the experiment incorporation of root-derived resources exceeded that of shoot residuederived resources by a factor of two, highlighting the importance of root-derived resources for arable soil food webs. Furthermore, at higher taxonomic resolution only few soil animal taxa predominantly relied on shoot residue-derived resources, while 
approximately $30 \%$ preferred root-derived resources, and half of the taxa were generalist feeders incorporating both shoot residue- and root-derived resources.

In a pulse labelling experiment (Chapter 4) I investigated the short-term incorporation of root-derived $\mathrm{C}$ and fertilizer $\mathrm{N}$ into the soil animal food web using ${ }^{13} \mathrm{CO}_{2}$ and $\mathrm{K}^{15} \mathrm{NO}_{3}$. Ratios of ${ }^{13} \mathrm{C} /{ }^{12} \mathrm{C}$ and ${ }^{15} \mathrm{~N} /{ }^{14} \mathrm{~N}$ were measured in bulk soil, maize shoots, roots and meso- and macrofauna, plus ${ }^{13} \mathrm{C} /{ }^{12} \mathrm{C}$ in nematodes and microbial phospholipid fatty acids over a period of 25 days. Both ${ }^{13} \mathrm{C}$ and ${ }^{15} \mathrm{~N}$ were incorporated into all compartments of the soil food web, with saprotrophic fungi incorporating by far the highest amounts of ${ }^{13} \mathrm{C}$, while higher trophic levels, i.e. nematodes and meso- and macrofauna, were less enriched. This suggests a prominent role of saprotrophic fungi in $\mathrm{C}$ and nutrient cycling in arable fields, but also that the majority of root-derived $\mathrm{C}$ remains locked up at the base of the food web. Further, higher amounts of ${ }^{13} \mathrm{C}$ in predators than decomposers of mesoand macrofauna indicate a prominent role of nematodes for transferring resources to higher trophic levels.

Overall, the present thesis highlights the importance of root-derived as compared to shoot residue-derived resources for arable soil food webs, thereby contributing to a better understanding of $\mathrm{C}$ and nutrient fluxes in agroecosystems. 
Chapter 1

\section{GENERAL INTRODUCTION}

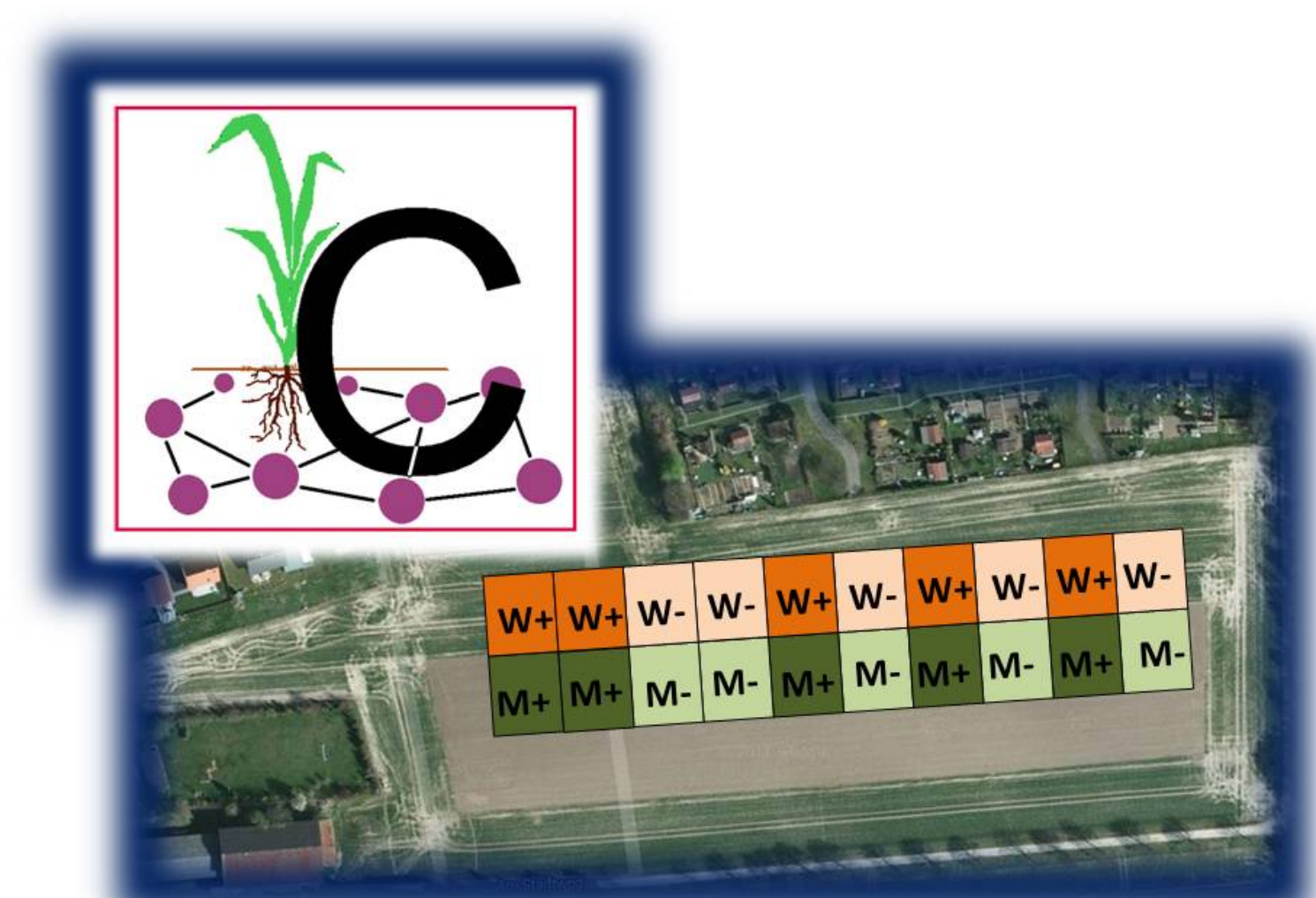




\section{Aboveground and belowground resources}

Soil contains more carbon (C) than the atmosphere and vegetation combined and plays a crucial role in regulating carbon dioxide $\left(\mathrm{CO}_{2}\right)$ concentration in the atmosphere and therefore the global climate (Lal, 2004a, 2004b). Detailed information is available on the composition, spatial distribution and residence time of soil organic matter, of which organic C is the largest single component (Sollins et al., 1996; Gaudinski et al., 2000; Kleber et al., 2011). The fate of organic $C$ in soil is determined by the quality and accessibility of $C$ inputs and environmental factors including soil texture, moisture, and temperature. However, we still only poorly understand how these factors create habitats and niches, and regulate biotic interactions to control the turnover of organic $C$ (Brüggemann et al., 2011); so this remains an important research area.

Organic $C$ enters the soil either aboveground as litter and woody debris or belowground in the form of root exudates and root litter, and these inputs profoundly differ in complexity and accessibility. Globally, $9 \times 10^{10}$ tons of litter enter the soil annually (Matthews, 1997), and in forests the input of aboveground litter forms the basic resource of the soil community (Ruess and Ferris, 2004). Litter decomposition is mainly achieved by saprotrophic soil microorganisms that synthesize new organic compounds from the decomposing substrate in a cascade of processes, with complex litter compounds like cellulose and lignin slowing down litter degradation and making litter derived $C$ less accessible for the soil food web (Berg and McClaugherty, 2003). Saprotrophic fungi generally dominate decomposition of litter as they are able to cope with local nutrient constraints by translocating external nutrients from patches of high nutritional quality to those of low quality via their hyphae (Lummer et al., 2012). Further, saprotrophic fungi produce a set of exoenzymes allowing to degrade complex litter compounds into labile compounds that can be assimilated to support heterotrophic metabolism (Hobbie and Horton, 2007; Osono, 2007). The incorporation of litter-derived resources into higher trophic levels of the soil food web usually takes a long time due to the low decomposability of litter and the slow metabolism of saprotrophic fungi, which is why the pathway of litter-derived $C$ through the food web is referred to as the slow "fungal energy channel" (Moore and Hunt, 1988; Moore et al., 2005). 
On average $17 \%$ of total photosynthetically fixed $C$ is released to the soil as root exudates (Kuzyakov and Domanski, 2000; Nguyen, 2003; Olsson and Johnson, 2005) and it has been shown that soil biota in disturbed habitats with shallow or absent litter layer e.g., arable fields predominantly rely on belowground inputs (Ruess and Ferris, 2004; Ngosong et al., 2009). While lacking structural compounds, root exudates provide resources in a soluble and easily available form like sugars and amino acids, making root exudates more easily accessible for uptake by soil microorganisms than litter (Bertin et al., 2003). Exudation by roots is an active process that enables plants to manipulate rhizosphere microorganisms to mobilize nutrients. The processes involved, such as the "microbial loop in soil", are increasingly recognized as driving forces for the flux of rootderived C through the soil food web (Bonkowski, 2004; Raynaud et al., 2006). Due to its high availability root-derived $\mathrm{C}$ released into the soil is rapidly incorporated by soil microorganisms and propagates to higher trophic levels via protists, nematodes, mesoand macrofauna (Leake et al., 2006; Högberg et al., 2010). Soil bacteria have long been assumed to dominate the exploitation of belowground inputs and due to the fast metabolism and turnover time the belowground energy pathway is also referred to as the fast “bacterial energy channel” (Moore and Hunt, 1988; Moore et al., 2005).

The traditional concept of $\mathrm{C}$ cycling in soils assumed a clear separation of the fungal and bacterial energy channel, with decomposition being achieved by fungi, while root exudates are the main resource of soil bacteria (Ruess and Ferris, 2004). However, recent studies have found saprotrophic fungi to be able to quickly utilize soluble resources in the soil including root exudates (Tavi et al., 2013; Balasooriya et al., 2014; Lemanski and Scheu, 2014), indicating that the compartmentalisation of energy channels in soil food webs is less stringent than previously assumed. Furthermore, evidence is accumulating that belowground resources may surpass aboveground resources in availability and importance for forest soil food webs (Ruf et al., 2006; Pollierer et al., 2007); an assumption that requires further investigation across ecosystems. The present thesis examines the contribution of shoot residue- and root-derived resources to the nutrition of species of higher trophic levels of the soil food web, i.e. soil meso- and macrofauna, in an arable system. 


\section{Soil food webs}

Soil food webs are highly diverse and extraordinarily complex, including microorganisms, protists, nematodes and other invertebrate taxa that interact and regulate important ecosystem functions including the cycling of $\mathrm{C}$ and nutrients (Buyanovsky and Wagner, 1998; Setälä, 2002; Högberg and Read, 2006). Soil microorganisms are the key organisms in decomposition, but higher trophic levels of soil animals critically affect the fate of $\mathrm{C}$ and $\mathrm{N}$ indirectly by hampering or supporting microorganisms. For instance, by feeding on litter soil animals fragment and pre-digest the litter during gut passage, thereby reducing the volume-to-surface ratio and facilitating microbial attack (Setälä and Huhta, 1990; Brussaard, 1998). However, soil animals may also reduce soil microbial activity and biomass by grazing on fungal hyphae and bacterial mats (Setälä and Huhta, 1990; Crowther et al., 2011). Although soil fauna plays a crucial role in cycling of $C$ and nutrients, there is still a lack of comprehensive knowledge on the role of particular fauna groups in driving these processes (Filser, 2002; Schneider et al., 2012), since research on decomposition and nutrient cycling in soil has mainly focussed on soil microorganisms (van der Heijden et al., 2008). Particularly in agroecosystems knowledge on the role of soil fauna in cycling of $C$ and nutrients is required to estimate impacts of soil fauna on cycling of $C$ and nutrients and increase sustainability (Brussaard, 1998; Brussaard et al., 2007; Birkhofer et al., 2011).

Meso- and macrofauna represent the top trophic levels of the soil food web and are usually categorized into distinct trophic groups, with primary decomposers feeding directly on litter material, secondary decomposers living on fungi and bacteria, and several levels of predators (Ponsard and Arditi, 2000; Chahartaghi et al., 2005; Illig et al., 2005). However, separation of individual species to distinct trophic groups is hampered by a high degree of omnivory and generalism (Gunn and Cherrett, 1993; Oelbermann and Scheu, 2010). Most soil fauna species feed on various resources and consume saprotrophic and mycorrhizal fungi, bacteria and algae (Endlweber et al., 2009; Buse et al., 2013), as well as nematodes and carcasses of other soil animals (Read et al., 2006; Heidemann et al., 2011). However, soil fauna species are "choosy generalists" with species specific preference to certain food items (Schneider and Maraun, 2005; Ngosong et al., 2009; Klarner et al., 2013), resulting in a continuum of feeding strategies from 


\section{General Introduction}

primary decomposers to secondary decomposers to predators (Scheu and Falca, 2000; Albers et al., 2006; von Berg et al., 2010).

\section{Arable soils}

Currently, the part of terrestrial land area used for cultivation is nearly $40 \%$ and will further increase in the near future, thereby increasing the importance of agroecosystems for cycling of $C$ and nutrients (Foley et al., 2005; Tilman et al., 2011). The fauna of arable fields has been intensively investigated, but while particular attention has been directed towards plant pests and their interactions with predators (e.g. Honek and Jarosik, 2000; Landis et al., 2005; von Berg et al., 2010), we still lack comprehensive understanding of how soil food webs are structured and function, and how they determine the cycling of $C$ and nutrients.

Arable soils profoundly differ from natural systems such as forests and grasslands. Harsh environmental conditions, including frequent disturbance, varying availability of resources, low habitat structure and absence of a continuous litter layer result in simple food webs with low abundance and diversity of soil fauna compared to grasslands and forests (Postma-Blaauw et al., 2010). These characteristics suggest that $\mathrm{C}$ and $\mathrm{N}$ dynamics in arable systems profoundly differ from those in natural ecosystems, and that processes that apply for forests or grassland ecosystems may not easily be transferred to agroecosystems.

The most important characteristic of arable systems is the frequent disturbance throughout the year. Tillage, seeding, application of herbicides, insecticides and fertilizer, and harvest result in a high degree of mechanical disturbance, including forceful opening of the soil but also soil compaction due to farming machines (Larsen et al., 2004). Many soil animal species are sensitive to mechanical disruption and soil compaction, and previous studies have shown that soil arthropod abundances decrease with intensification of agricultural management (Neher, 1999; Wardle et al., 1999; Holland and Luff, 2000; Alvarez et al., 2001). Species able to cope with frequent disturbance therefore dominate the soil fauna community in arable fields. For example, many soil animal species in arable soils reproduce by parthenogenesis and are able to rapidly colonize disturbed areas (Bardgett and Cook, 1998; Behan-Pelletier, 1999). Further, species 


\section{General Introduction}

common in disturbed ecosystems tend to be of low body size and retract to soil layers below the plough layer to escape agricultural management (Wardle et al., 1995).

Soil arthropods in arable fields have to cope with variations in resource availability across the growing season. While crop plants release high amounts of root exudates to the soil during growth, exudation is slowed down with ripeness of the crop (Hamlen et al., 1972). More importantly, after harvest only dead roots remain in the soil, whereas perennial plants such as trees, continuously release root exudates in winter and provide belowground resources more constantly.

The availability of litter as aboveground resource depends on the amount of litter added to the ecosystem and on litter quality (Melillo et al., 1982, 1989). Crop litter, in particular that of C4 crops is of low food quality with high amounts of structural compounds and high $\mathrm{C} / \mathrm{N}$ ratio, resulting in a very low decomposability (Caswell and Reed, 1976). Addition of crop litter may improve abiotic conditions for soil arthropods in arable fields (Halaj and Wise, 2002), but abundances are usually restricted by the high degree of disturbance in agroecosystems (Behan-Pelletier, 2003).

In recent years, the removal of crop residues in favour of biofuel production has become a frequently used practice in arable fields. The consequences of crop residue removal require investigation, since the strong decline in food availability for soil fauna may critically affect fauna abundances and/or community composition that may influence soil microorganisms and therefore cycling of $C$ and nutrients in arable soils. The removal of crop residues therefore is likely to result in simple food webs driven by belowground resources and dominated by the bacterial energy channel. Particularly after harvest when root exudates are no longer available, decreasing abundances of soil arthropods or severe changes in community composition can be expected.

\section{Stable isotope analysis}

Most elements occur in multiple isotopes that possess the same number of protons, but differ in the number of neutrons. Isotopes of the same element chemically behave similar, while the variance in number of neutrons results in different atomic masses and therefore physical and biochemical differences, e.g. in enzyme kinetics (see below; Fry, 
2007). The majority of isotopes are unstable radioisotopes that decay with time. In the process of decay the nucleus of the unstable atom breaks down, thereby emitting highly energetic, ionizing radiation. Scientific utilization of radioisotope tracers has a long history (e.g. Buchanan, 1961) and in nuclear medicine radiation derived from radioactivity is used for sterilization of medical tools, diagnosis and treatment since the late 1940s [reviewed in Veall and Vetter (1958)]. However, the use of radioisotopes is attended with danger, since ionizing radiation damages tissue DNA and other key molecules.

Stable isotopes, in contrast, do not undergo radioactive decay, making them more easy and safe to handle. The existence of multiple stable isotopes of a single element was first discovered in the beginning of the $20^{\text {th }}$ century by mass spectrography (Soddy, 1922). The first application of stable isotopes was the estimation of rock and fossil ages and was achieved by geochemists, who associated ratios of different oxygen, carbon and nitrogen isotopes in inorganic material with the climatic conditions at the time the material was build (Craig, 1953). In the 1950s scientists discovered that biochemical processes often result in changes in isotope ratios (Wickman, 1952), called fractionation. Enzyme kinetics are the key drivers of fractionation processes and lead to an enrichment or depletion of the heavier stable isotope in the product (Macko et al., 1987; Farquhar et al., 1989). These changes are generally very small and are expressed by the delta notation that illustrates differences between the sample and an international standard in per mill [\%o].

One of the first processes revealed to cause fractionation was photosynthesis. During photosynthesis, every year 110,000 metric tons of $C$ are converted from inorganic $\mathrm{CO}_{2}$ to organic molecules, with green plants achieving the gross photosynthesis in terrestrial ecosystems (Field, 1998). The photosynthetic pathway affects fractionation strength (Farquhar et al., 1989), resulting in distinct ${ }^{13} \mathrm{C} /{ }^{12} \mathrm{C}$ ratios, i.e. ${ }^{13} \mathrm{C}$ signatures. The majority of terrestrial plants follow the $\mathrm{C} 3$ photosynthetic pathway, with fixation of $\mathrm{CO}_{2}$ by the enzyme ribulose-1,5-bisphosphate-carboxylase/oxygenase (RuBisCO) that produces organic molecules containing three $\mathrm{C}$ atoms, thereby fractionating against ${ }^{13} \mathrm{C}$. Plant material produced by the C3 photosynthetic pathway is depleted in ${ }^{13} \mathrm{C}$ by -24 to -33\%o (Tcherkez et al., 2011). C4 plants, on the contrary, fix $\mathrm{CO}_{2}$ in mesophyll cells where $\mathrm{CO}_{2}$ is bound by phosphoenol-pyruvate (PEP), forming a four-carbon molecule. The enzyme performing this reaction (PEP-carboxylase) fractionates less against ${ }^{13} \mathrm{C}$ than 
RuBisCO, resulting in plant material depleted in ${ }^{13} \mathrm{C}$ by only -10 to $-20 \%$ (Tcherkez et al., 2011). Since the ${ }^{13} \mathrm{C}$ signature remains almost constant along food chains (Petersen and Fry, 1987) the natural difference in ${ }^{13} \mathrm{C}$ signatures between $\mathrm{C} 3$ and $\mathrm{C} 4$ plants allows separation of basic C sources in consumers: "You are what you eat" (DeNiro and Epstein, 1976, 1978).

Another stable isotope that draws considerable attention in ecological studies is ${ }^{15} \mathrm{~N}$. Nitrogen is the most important nutrient for plants as well as heterotrophs, and is needed for synthesis of amino and nucleic acids (Macko et al., 1987). Many biologically mediated reactions lead to the depletion of ${ }^{15} \mathrm{~N}$ in the product due to fractionation by various enzymes involved in these processes. In particular in the case of excretion where enriched faeces are released to the environment, fractionation leads to ${ }^{15} \mathrm{~N}$ enrichment in animal tissues. Early studies concerning the enrichment in ${ }^{15} \mathrm{~N}$ in consumer tissue revealed an almost constant increase in the ${ }^{15} \mathrm{~N} /{ }^{14} \mathrm{~N}$ ratio by $3.4 \%$ in every trophic level (Minagawa and Wada, 1984; Gannes et al., 1998; Post, 2002), allowing the construction of hierarchical food webs (DeNiro and Epstein, 1978).

Since the early 1970 s stable isotopes of $\mathrm{C}$ and $\mathrm{N}$ were used to disentangle feeding strategies of terrestrial, marine and freshwater species (e.g., Scheu and Falca, 2000). The combined analysis of ${ }^{13} \mathrm{C}$ and ${ }^{15} \mathrm{~N}$ signatures provided increasing insight in food web structure, with the trophic level of a species being indicated by its natural ${ }^{15} \mathrm{~N}$ signature, while the constant ${ }^{13} \mathrm{C}$ signature of resource and consumer only reveals insight into species-specific feeding habits when using isotopically distinct resources, e.g. C3 vs. C4 plants. Differences in ${ }^{13} \mathrm{C}$ signatures between $\mathrm{C} 3$ and $\mathrm{C} 4$ plants have been used to estimate the percentage of C3- and C4-derived C in consumers using mixing models, thereby revealing preferences for different resources in single species (Scheu and Folger, 2004; Albers et al., 2006; Fry, 2013).

However, the small differences between naturally enriched or depleted tissues only reveal the average feeding behaviour of a species, while the specific introduction of artificially high enriched (or depleted) resources is an elaborate tool to unravel fluxes of energy and nutrients within the food web, e.g. by pulse labelling plants with $99 \%$ enriched ${ }^{13} \mathrm{CO}_{2}$ or $\mathrm{K}^{15} \mathrm{NO}_{3}$. Pulse labelling is usually followed by a continuous measurement of the stable isotope ratios in distinct food web members (roots, soil 
microorganisms, fauna) over a certain time period, resulting in a time-integrated tracing of $\mathrm{C}$ and/or $\mathrm{N}$ fluxes through the food web (Fitter et al., 2005; Epron et al., 2012).

\section{Study site and experimental design}

The experimental agricultural field is located in Göttingen (Lower Saxony, Germany). Göttingen is of temperate climate with an annual precipitation of $645 \mathrm{~mm}(340 \mathrm{~mm}$ during the growth period between May and September), and an average temperature of $8.7^{\circ} \mathrm{C}$. The elevation of the experimental field is $160 \mathrm{~m}$ a.s.l., and it belongs to a plain of the river Leine that is striking north-west with an approximate slope of $2 \%$ (see Kramer et al., 2012). The parent rock of the area is limestone originating from Triassic deposits of the Middle Keuper. The dominant soil type is stagnic luvisol that is severely affected by decades of frequent agricultural cultivation. $C$ and $N$ content of the uppermost $10 \mathrm{~cm}$ is $11.6 \pm 0.2 \%$ and $1.2 \pm 0.0 \%$, respectively, with an average $\mathrm{C} / \mathrm{N}$ ratio of $9.7 \pm 0.1$ (see Kramer et al., 2012). Before the establishment of the experiment, the agricultural field has been continuously planted with C3 crops.

The factorial design of the experiment included two adjacent rows of $24 \times 240 \mathrm{~m}$ planted with wheat and maize, respectively. Both rows were separated into 10 plots of 24 x $24 \mathrm{~m}$ each. We chose wheat and maize as crop since both are of the family Poaceae and are common crops in central Europe. Wheat follows the C3 photosynthetic pathway, while maize follows the C4 pathway, resulting in isotopic shifts in consumer species (see above). Winter wheat ("Julius" KWS Saat AG, Einbeck, Germany) was sown in October 2008 at a density of 380 grains $\mathrm{m}^{-2}$, followed by the application of nitrate-sulfate fertilizer $\left(21.0 \mathrm{~kg} \mathrm{~N} \mathrm{ha}^{-1}, 24.0 \mathrm{~kg} \mathrm{~S} \mathrm{ha}^{-1}\right)$ in March 2009 and four times fertilisation with ammonium nitrate urea solution (50.4 $\mathrm{kg} \mathrm{N} \mathrm{ha}^{-1}$ each) in April, May and June 2009. Maize plots were initially treated with herbicide ("Round up", Monsanto Agrar, Düsseldorf, Germany) to remove herbs and wheat seedlings. In April 2009 maize ("Ronaldinio" KWS Saat AG, Einbeck, Germany) was sown at a density of 11.5 grains $\mathrm{m}^{-2}$. Before and after seeding of maize the soil was fertilized with ammonium nitrate urea solution (122.4 kg N ha ${ }^{-1}$ ) and diammonium phosphate $\left(32.4 \mathrm{~kg} \mathrm{~N} \mathrm{ha}^{-1}, 82.8 \mathrm{~kg} \mathrm{P} \mathrm{ha}^{-1}\right)$. Herbicide was added twice to the maize plots and six times to the wheat plots during growth (see Kramer et al., 2012). At 


\section{General Introduction}

both wheat and maize plots, tillage practice was changed from deep tillage to chisel plough tillage to a depth of $12 \mathrm{~cm}$.

Wheat was harvested in August 2009, with wheat plants being cut $10 \mathrm{~cm}$ above the soil surface and removed from the plots, while wheat roots remained at the plots during winter. In autumn, winter wheat seedlings that originated from grains lost during harvest recruited on the wheat plots. They grew to a height of $10 \mathrm{~cm}$, remained at the plots during winter and were buried during tillage in spring 2010. After harvest of maize cobs in October 2009, maize plants were cut at a height of $10 \mathrm{~cm}$ above soil surface, and residues (including shoots but without cobs) were hackled to particles of $1 \mathrm{~cm}^{2}$. Hackled maize residues were added to half the maize and wheat plots at an amount of $0.8 \mathrm{~kg}$ dry weight $\mathrm{m}^{-2}$. With maize residue addition we established four treatments: maize plants with $(\mathrm{M}+)$ and without $(\mathrm{M}-)$ maize residues, and wheat plants with $(\mathrm{W}+)$ and without $(\mathrm{W}-)$ maize residues, referring to maize $\mathrm{C}$ offered above and belowground, only belowground, only aboveground, and no maize $C$, respectively. Maize residues remained the soil surface during winter and were incorporated into the soil during tillage in the following spring. Maize roots remained at the plots during winter and were buried in spring during tillage.

In April 2010 all plots were tilled to a depth of $12 \mathrm{~cm}$ using a chisel plough. Afterwards, maize ("Fernandez" KWS Saat AG, Einbeck, Germany; 12.1 grains $\mathrm{m}^{-2}$ ) was sown at the same plots as in the previous year, while instead of winter wheat, summer wheat ("Melon" Saaten-Union $\mathrm{GmbH}$, Isernhagen, Germany; 440 grains $\mathrm{m}^{-2}$ ) was sown at the respective plots to improve comparability of growing seasons in maize and wheat. Maize was fertilized with ammonium nitrate urea solution $\left(79.2 \mathrm{~kg} \mathrm{~N} \mathrm{ha}{ }^{-1}\right.$ ) and diammonium phosphate (32.4 $\left.\mathrm{kg} \mathrm{N} \mathrm{ha}^{-1}, 82.8 \mathrm{~kg} \mathrm{P} \mathrm{ha}^{-1}\right)$ before and after seeding. Wheat was fertilized with ammonium nitrate urea solution in April and June (61.3 and $39.5 \mathrm{~kg} \mathrm{~N}$ $\mathrm{ha}^{-1}$, respectively). Herbicide was added twice to the maize plots and once to the wheat plots during the growing season in 2010 (see Kramer et al., 2012). Both wheat and maize were harvested in early November 2010, with wheat residues being removed from the plots, while maize residues (without cobs) were hackled and added to the same plots as in the previous year at an amount of $0.8 \mathrm{~kg}$ dry weight $\mathrm{m}^{-2}$. Roots of maize and wheat plants remained in the soil during winter. Until 2013 the experimental field was managed as in 2010. 


\section{Study objectives and hypotheses}

The present thesis was part of the DFG research unit FOR 918 "Carbon flow in belowground food webs assessed by isotope tracers" that consisted of nine subprojects. The project aims at understanding $C$ fluxes through biotic and abiotic compartments of soil ecosystems using isotope tracers in an arable field. To track $C$ flux in the field, soil samples were taken in July, September and December in 2009 and 2010. The sampling times referred to maize growth phases with flowering and high root exudation in July and mature stands shortly before harvest in September. In December low temperatures induced high turnover of soil organic matter in the rhizosphere. Starting 2011, plots were sampled only once per year in September to monitor long term dynamics in the field. The data used in the present thesis were gathered between July 2009 and July 2010, considering dynamics of $C$ transfer and soil arthropod abundances within the first year of the experiment. Thereby I focussed on the effects of different crop species and addition of crop residues on diversity and abundance of soil arthropods, and disentangled the importance of root- and shoot residue-derived resources for the soil arthropod food web.

The investigated crop species wheat and maize are following the C3 and C4 photosynthetic pathway, respectively, with the experimental maize and wheat field being established on a former C3 crop agricultural field. In the first study, abundance and diversity of soil arthropod species in wheat and maize plots were estimated through the first year of the experiment. By addition of maize residues to half the maize and wheat plots, I investigated effects of increased food availability and habitat structure on the soil arthropod community (Chapter 2). Using ${ }^{13} \mathrm{C}$ natural abundances of wheat and maize, preferences of soil arthropods for shoot residue- or root-derived $\mathrm{C}$ as basic resource were inspected shortly after maize establishment and after one year of maize crop (Chapter 3 ). Finally, I investigated the incorporation of recently assimilated $C$ into the soil food web in a pulse labelling experiment using ${ }^{13} \mathrm{CO}_{2}$ assimilated by maize plants in the field. That experiment was conducted jointly by four PhD students of the DFG research unit with Johanna Pausch (University of Bayreuth) in the leading position. We tracked the flux of ${ }^{13} \mathrm{C}$ through all compartments of the soil food web with my work focussing on trophic groups of soil arthropods. We also added $\mathrm{K}^{15} \mathrm{NO}_{3}$ to the soil to inspect incorporation of fertilizerderived nutrients into soil food web members (Chapter 4). In all three studies, soil 


\section{General Introduction}

arthropods were identified to species level or the highest possible taxonomic resolution to account for species specific feeding strategies and to ensure comparability of the taxa between all studies within the framework of this thesis.

The following hypotheses were investigated:

Addition of shoot residues to arable fields enhances the abundance and diversity of soil arthropod species by increasing resource availability and habitat structure (Chapter 2).

Root-derived $\mathrm{C}$ is of higher importance and will be incorporated by soil arthropods to higher extents than shoot residue-derived C (Chapter 3 ).

The amount of C4 carbon incorporated by soil arthropods increases with time due to continuous release of maize $C$ to the soil (Chapter 3 ).

The incorporation of recently assimilated $\mathrm{C}$ and $\mathrm{N}$ is critically affected by the trophic position, with higher trophic levels incorporating less ${ }^{13} \mathrm{C}$ and ${ }^{15} \mathrm{~N}$ due to dilution of the label with every trophic step (Chapter 4).

Incorporation of recently assimilated $\mathrm{C}$ and $\mathrm{N}$ is affected by tropic position due to an increasing time-lag between pulse labelling and incorporation with increasing trophic level (Chapter 4).

\section{Chapter outline}

Chapter 2: In this chapter, I addressed the question of resource limitation of soil arthropods in arable fields by adding maize residues to wheat and maize plots and estimating abundance and diversity of soil arthropod taxa. The community structure of the arable soil food web was not affected by the shoot residue-mediated increase in food supply and habitat structure. In contrast, the crop species strongly affected the soil 


\section{General Introduction}

arthropod community composition with higher abundances and diversity in wheat than maize, presumably due to more dense and more continuous coverage by plants and higher input of root residues. Furthermore, strong seasonal variances of soil arthropod abundance in wheat but not maize fields indicate more pronounced pulses of root exudates and root residues in wheat, while in maize the low abundances varied little with crop coverage and season. The results point to a remarkable lack of importance of aboveground crop residues for soil arthropod communities and highlight that belowground plant resources, i.e. root exudates and root residues, are the major drivers of soil arthropod communities of arable systems.

Chapter 3: Using natural abundance ${ }^{13} \mathrm{C} /{ }^{12} \mathrm{C}$ signatures of wheat and maize plants, the incorporation of maize-borne $C$ into soil arthropods was investigated over a period of 14 months and the contribution of shoot residue- and root-derived $C$ to soil arthropod nutrition was quantified. The average amount of root-derived maize $\mathrm{C}$ incorporated into soil arthropods was $23 \%$ two months after establishment of the experiment, and further increased to $34 \%$ within one year, suggesting that root-derived resources are easily available for soil arthropods. Incorporation of shoot residue-derived resources, in contrast, averaged only 15\%, revealing low importance of shoot residues as basal resource in arable soil food webs. Although generalist feeding was the most common feeding strategy, at higher taxonomic resolution different incorporation patterns were distinguished, with few species relying predominantly on shoot residues, while preference to root-derived resources was found for nearly $30 \%$ of the taxa.

Chapter 4: In a pulse labelling experiment using ${ }^{13} \mathrm{CO}_{2}$ and $\mathrm{K}^{15} \mathrm{NO}_{3}$, I measured the incorporation of root-derived ${ }^{13} \mathrm{C}$ and fertilizer-derived ${ }^{15} \mathrm{~N}$ into plant tissue, soil and soil arthropods, and the incorporation of ${ }^{13} \mathrm{C}$ into soil microorganisms and nematodes over a period of 25 days. ${ }^{13} \mathrm{C}$ was incorporated into all food web compartments, including higher trophic levels, i.e. nematodes and soil arthropods. The ${ }^{13} \mathrm{C}$ signature remained constant in meso- and macrofauna decomposers suggesting that they fed close to the base of the food web, while in predator body tissue ${ }^{13} \mathrm{C}$ increased continuously suggesting increasing flow of root-derived $\mathrm{C}$ towards higher trophic levels. The remarkably high incorporation 
into saprotrophic fungi and fungivorous nematodes and mesofauna indicated a central role of the fungal energy channel in arable soil food webs. Further, the simultaneous incorporation of root-derived ${ }^{13} \mathrm{C}$ and fertilizer-derived ${ }^{15} \mathrm{~N}$ into soil arthropods indicated that arable soil food webs are provided with $\mathrm{C}$ resources and nutrients simultaneously via feeding on saprotrophic fungi.

\section{References}

Albers, D., Schaefer, M., Scheu, S., 2006. Incorporation of plant carbon into the soil animal food web of an arable system. Ecology 87, 235-245.

Alvarez, T., Frampton, G.K., Goulson, D., 2001. Epigeic Collembola in winter wheat under organic, integrated and conventional farm management regimes. Agriculture, Ecosystems \& Environment 83, 95-110.

Balasooriya, W.K., Denef, K., Huygens, D., Boeckx, P., 2014. Translocation and turnover of rhizodeposit carbon within soil microbial communities of an extensive grassland ecosystem. Plant and Soil 376, 61-73.

Bardgett, R.D., Cook, R., 1998. Functional aspects of soil animal diversity in agricultural grasslands. Applied Soil Ecology 10, 263-276.

Behan-Pelletier, V.M., 1999. Oribatid mite biodiversity in agroecosystems: Role for bioindication. Ariculture, Ecosystems and Environment 74, 411-423.

Behan-Pelletier, V.M., 2003. Acari and Collembola biodiversity in Canadian agricultural soils. Canadian Journal of Soil Science 83, 279-289.

Berg, B., McClaugherty, C., 2003. Plant Litter: Decomposition, humus formation, carbon sequestration, 2nd ed. Springer, Berlin, Heidelberg, New York.

Bertin, C., Yang, X., Weston, L.A., 2003. The role of root exudates and allelochemicals in the rhizosphere. Plant and Soil 256, 67-83.

Birkhofer, K., Fließbach, A., Wise, D.H., Scheu, S., 2011. Arthropod food webs in organic and conventional wheat farming systems of an agricultural long-term experiment: A stable isotope approach. Agricultural and Forest Entomology 13, 197-204.

Bonkowski, M., 2004. Protozoa and plant growth: The microbial loop in soil revisited. New Phytologist 162, 617-631. 
Brüggemann, N., Gessler, A., Kayler, Z.E., Keel, S.G., Badeck, F., Barthel, M., Boeckx, P., Buchmann, N., Brugnoli, E., Esperschütz, J., Gavrichkova, O., Ghashghaie, J., GomezCasanovas, N., Keitel, C., Knohl, A., Kuptz, D., Palacio, S., Salmon, Y., Uchida, Y., Bahn, M., 2011. Carbon allocation and carbon isotope fluxes in the plant-soil-atmosphere continuum: A review. Biogeosciences 8, 3457-3489.

Brussaard, L., 1998. Soil fauna, guilds, functional groups and ecosystem processes. Applied Soil Ecology 9, 123-135.

Brussaard, L., de Ruiter, P.C., Brown, G.G., 2007. Soil biodiversity for agricultural sustainability. Agriculture, Ecosystems \& Environment 121, 233-244.

Buchanan, D., 1961. Total carbon turnover measured by feeding a uniformly labeled diet. Archieves of Biochemistry and Biophysics 94, 500-511.

Buse, T., Ruess, L., Filser, J., 2013. New trophic biomarkers for Collembola reared on algal diets. Pedobiologia 56, 153-159.

Buyanovsky, G.A., Wagner, G.H., 1998. Carbon cycling in cultivated land and its global significance. Global Change Biology 4, 131-141.

Caswell, H., Reed, F.C., 1976. Plant-herbivore interactions: The indigestibility of C4 bundle sheath cells by grasshoppers. Oecologia 26, 151-156.

Chahartaghi, M., Langel, R., Scheu, S., Ruess, L., 2005. Feeding guilds in Collembola based on nitrogen stable isotope ratios. Soil Biology \& Biochemistry 37, 1718-1725.

Craig, H., 1953. The geochemistry of the stable carbon isotopes. Geochimica et Cosmochimica Acta 3, 53-92.

Crowther, T.W., Boddy, L., Jones, T.H., 2011. Species-specific effects of soil fauna on fungal foraging and decomposition. Oecologia 167, 535-545.

DeNiro, M.J., Epstein, S., 1976. You are what you eat (plus a few \%o): The carbon isotope cycle in food chains, in: Geological Society of America Annual Meeting. Denver, Colorado, USA, pp. 834-835.

DeNiro, M.J., Epstein, S., 1978. Influence of diet on the distribution of carbon isotopes in animals. Geochimica et Cosmochimica Acta 42, 495-506.

Endlweber, K., Ruess, L., Scheu, S., 2009. Collembola switch diet in presence of plant roots thereby functioning as herbivores. Soil Biology \& Biochemistry 41, 1151-1154. 
Epron, D., Bahn, M., Derrien, D., Lattanzi, F.A., Pumpanen, J., Gessler, A., Högberg, P., Maillard, P., Dannoura, M., Gérant, D., Buchmann, N., 2012. Pulse-labelling trees to study carbon allocation dynamics: A review of methods, current knowledge and future prospects. Tree Physiology 32, 776-98.

Farquhar, G.D., Ehleringer, J.R., Hubick, K.T., 1989. Carbon isotope discrimination and photosynthesis. Annual Review of Plant Physiology and Plant Molecular Biology 40, 503-537.

Field, C.B., 1998. Primary production of the biosphere: Integrating terrestrial and oceanic components. Science 281, 237-240.

Filser, J., 2002. The role of Collembola in carbon and nitrogen cycling in soil. Pedobiologia $245,234-245$.

Fitter, A.H., Gilligan, C.A., Hollingworth, K., Kleczkowski, A., Twyman, R.M., Pitchford, J.W., the members of the N.S.B. Programme, 2005. Biodiversity and ecosystem function in soil. Functional Ecology 19, 369-377.

Foley, J.A, Defries, R., Asner, G.P., Barford, C., Bonan, G.B., Carpenter, S.R., Chapin, F.S., Coe, M.T., Daily, G.C., Gibbs, H.K., Helkowski, J.H., Holloway, T., Howard, E.A, Kucharik, C.J., Monfreda, C., Patz, J.A, Prentice, I.C., Ramankutty, N., Snyder, P.K., 2005. Global consequences of land use. Science 309, 570-574.

Fry, B., 2007. Stable Isotope Ecology, 1st ed. Springer Science \& Business Media, New York.

Fry, B., 2013. Alternative approaches for solving underdetermined isotope mixing problems. Marine Ecology Progress Series 472, 1-13.

Gannes, L.Z., Martinez del Rio, C., Koch, P.L., 1998. Natural abundance variations in stable isotopes and their use in animal physiological ecology. Comparative Biochemistry and Physiology 119, 725-737.

Gaudinski, J.B., Trumbore, S.E., Davidson, E.A., Zheng, S., 2000. Soil carbon cycling in a temperate forest: Radiocarbon-based estimates of residence times, sequestration rates and partitioning of fluxes. Biogeochemistry 51, 33-69.

Gunn, A., Cherrett, J.M., 1993. The exploitation of food resources by soil meso- and macrofauna invertebrates. Pedobiologia 37, 303-320. 
Halaj, J., Wise, D.H., 2002. Impact of a detrital subsidy on trophic cascades in a terrestrial grazing food web. Ecology 83, 3141-3151.

Hamlen, R.A., Lukezic, F.L., Bloom, J.R., 1972. Influence of age and stage of development on the neutral carbohydrate components in root exudates from alfalfa plants grown in a gnotobiotic environment. Canadian Journal of Plant Science 52, 633-642.

Heidemann, K., Scheu, S., Ruess, L., Maraun, M., 2011. Molecular detection of nematode predation and scavenging in oribatid mites: Laboratory and field experiments. Soil Biology \& Biochemistry 43, 2229-2236.

Hobbie, E.A., Horton, T.R., 2007. Evidence that saprotrophic fungi mobilise carbon and mycorrhizal fungi mobilise nitrogen during litter decomposition. New Phytologist $173,447-449$.

Högberg, M.N., Briones, M.J.I., Keel, S.G., Metcalfe, D.B., Campbell, C.D., Midwood, A.J., Thornton, B., Hurry, V., Linder, S., Näsholm, T., Högberg, P., 2010. Quantification of effects of season and nitrogen supply on tree below-ground carbon transfer to ectomycorrhizal fungi and other soil organisms in a boreal pine forest. New Phytologist 187, 485-493.

Högberg, P., Read, D.J., 2006. Towards a more plant physiological perspective on soil ecology. Trends in Ecology and Evolution 21, 548-554.

Holland, J.M., Luff, M.L., 2000. The effects of agricultural practices on Carabidae in temperate agroecosystems. Integrated Pest Management Reviews 5, 109-129.

Honek, A., Jarosik, V., 2000. The role of crop density, seed and aphid presence in diversification of field communities of Carabidae (Coleoptera). European Journal of Entomology 97, 517-525.

Illig, J., Langel, R., Norton, R.A., Scheu, S., Maraun, M., 2005. Where are the decomposers? Uncovering the soil food web of a tropical montane rain forest in southern Ecuador using stable isotopes $\left({ }^{15} \mathrm{~N}\right)$. Journal of Tropical Ecology 21, 589593.

Klarner, B., Maraun, M., Scheu, S., 2013. Trophic diversity and niche partitioning in a species rich predator guild - Natural variations in stable isotope ratios $\left({ }^{13} \mathrm{C} /{ }^{12} \mathrm{C}\right.$, ${ }^{15} \mathrm{~N} /{ }^{14} \mathrm{~N}$ ) of mesostigmatid mites (Acari, Mesostigmata) from Central European beech forests. Soil Biology \& Biochemistry 57, 327-333. 
Kleber, M., Nico, P.S., Plante, A., Filley, T.R., Kramer, M., Swanston, C.W., Sollins, P., 2011. Old and stable soil organic matter is not necessarily chemically recalcitrant: Implications for modeling concepts and temperature sensitivity. Global Change Biology 17, 1097-1107.

Kramer, S., Marhan, S., Ruess, L., Armbruster, W., Butenschoen, O., Haslwimmer, H., Kuzyakov, Y., Pausch, J., Scheunemann, N., Schoene, J., Schmalwasser, A., Totsche, K.U., Walker, F., Scheu, S., Kandeler, E., 2012. Carbon flow into microbial and fungal biomass as a basis for the belowground food web of agroecosystems. Pedobiologia $55,111-119$.

Kuzyakov, Y., Domanski, G., 2000. Carbon input by plants into the soil. Review. Journal of Plant Nutrition and Soil Science 163, 421-431.

Lal, R., 2004a. Soil carbon sequestration impacts on global climate change and food security. Science 304, 1623-1627.

Lal, R., 2004b. Soil carbon sequestration to mitigate climate change. Geoderma 123, 1-22. Landis, D.A., Menalled, F.D., Costamagna, A.C., Wilkinson, T.K., 2005. Manipulating plant resources to enhance beneficial arthropods in agricultural landscapes. Weed Science 53, 902-908.

Larsen, T., Schjønning, P., Axelsen, J., 2004. The impact of soil compaction on euedaphic Collembola. Applied Soil Ecology 26, 273-281.

Leake, J.R., Ostle, N.J., Rangel-Castro, J.I., Johnson, D., 2006. Carbon fluxes from plants through soil organisms determined by field ${ }^{13} \mathrm{CO}_{2}$ pulse-labelling in an upland grassland. Applied Soil Ecology 33, 152-175.

Lemanski, K., Scheu, S., 2014. Incorporation of ${ }^{13} \mathrm{C}$ labelled glucose into soil microorganisms of grassland: Effects of fertilizer addition and plant functional group composition. Soil Biology \& Biochemistry 69, 38-45.

Lummer, D., Scheu, S., Butenschoen, O., 2012. Connecting litter quality, microbial community and nitrogen transfer mechanisms in decomposing litter mixtures. Oikos $121,1649-1655$.

Macko, S.A., Fogel, M.L., Hare, P.E., Hoering, T.C., 1987. Isotopic fractionation of nitrogen and carbon in the synthesis of amino acids by microorganisms. Chemical Geology: Isotope Geoscience Section 65, 79-92. 
Matthews, E., 1997. Global litter production, pools, and turnover times: Estimates from measurement data and regression models. Journal of Geophysical Research 102, 18771-18800.

Melillo, J.M., Aber, J.D., Linkins, A.E., Ricca, A., Fry, B., Nadelhoffer, K.J., 1989. Carbon and nitrogen dynamics along the decay continuum: Plant litter to soil organic matter. Plant and Soil 115, 189-198.

Melillo, J.M., Aber, J.D., Muratore, J.F., 1982. Nitrogen and lignin control of hardwood leaf litter decomposition dynamics. Ecology 63, 621-626.

Minagawa, M., Wada, E., 1984. Stepwise enrichment of ${ }^{15} \mathrm{~N}$ along food chains: Further evidence and the relation between $\delta^{15} \mathrm{~N}$ and animal age. Geochimica et Cosmochimica Acta 48, 1135-1140.

Moore, J.C., Hunt, H.W., 1988. Resource compartmentation and the stability of real ecosystems. Nature 333, 261-263.

Moore, J.C., McCann, K.S., De Ruiter, P.C., 2005. Modeling trophic pathways, nutrient cycling, and dynamic stability in soils. Pedobiologia 49, 499-510.

Neher, D.A., 1999. Soil community composition and ecosystem processes: Comparing agricultural ecosystems with natural ecosystems. Agroforestry Systems 45, 159-185.

Ngosong, C., Raupp, J., Scheu, S., Ruess, L., 2009. Low importance for a fungal based food web in arable soils under mineral and organic fertilization indicated by Collembola grazers. Soil Biology \& Biochemistry 41, 2308-2317.

Nguyen, C., 2003. Rhizodeposition of organic C by plants: Mechanisms and controls. Agronomie 23, 375-396.

Oelbermann, K., Scheu, S., 2010. Trophic guilds of generalist feeders in soil animal communities as indicated by stable isotope analysis $\left({ }^{15} \mathrm{~N} /{ }^{14} \mathrm{~N}\right)$. Bulletin of Entomological Research 100, 511-520.

Olsson, P.A., Johnson, N.C., 2005. Tracking carbon from the atmosphere to the rhizosphere. Ecology Letters 8, 1264-1270.

Osono, T., 2007. Ecology of ligninolytic fungi associated with leaf litter decomposition. Ecological Research 22, 955-974.

Petersen, B.J., Fry, B., 1987. Stable isotopes in ecosystem studies. Annual Review of Ecology, Evolution and Systematics 18, 293-320. 
Pollierer, M.M., Langel, R., Körner, C., Maraun, M., Scheu, S., 2007. The underestimated importance of belowground carbon input for forest soil animal food webs. Ecology Letters 10, 729-736.

Ponsard, S., Arditi, R., 2000. What can stable isotopes $\left(\delta^{15} \mathrm{~N}\right.$ and $\left.\delta^{13} \mathrm{C}\right)$ tell about the food web of soil macro-invertebrates? Ecology 81, 852-864.

Post, D.M., 2002. Using stable isotopes to estimate trophic position: Models, methods, and assumptions. Ecology 83, 703-718.

Postma-Blaauw, M.B., De Goede, R.G.M., Bloem, J., Faber, J., Brussaard, L., 2010. Soil biota community structure and abundance under agricultural intensification and extensification. Ecology 91, 460-473.

Raynaud, X., Lata, J.-C., Leadley, P.W., 2006. Soil microbial loop and nutrient uptake by plants: A test using a coupled $\mathrm{C}: \mathrm{N}$ model of plant-microbial interactions. Plant and Soil $287,95-116$.

Read, D.S., Sheppard, S.K., Bruford, M.W., Glen, D.M., Symondson, W.O.C., 2006. Molecular detection of predation by soil micro-arthropods on nematodes. Molecular Ecology 15, 1963-1972.

Ruess, L., Ferris, H., 2004. Decomposition pathways and successional changes. Nematology Monographs \& Perspectives 2, 547-556.

Ruf, A., Kuzyakov, Y., Lopatovskaya, O., 2006. Carbon fluxes in soil food webs of increasing complexity revealed by ${ }^{14} \mathrm{C}$ labelling and ${ }^{13} \mathrm{C}$ natural abundance. Soil Biology \& Biochemistry 38, 2390-2400.

Scheu, S., Falca, M., 2000. The soil food web of two beech forests (Fagus sylvatica) of contrasting humus type: Stable isotope analysis of a macro- and a mesofaunadominated community. Oecologia 123, 285-296.

Scheu, S., Folger, M., 2004. Single and mixed diets in Collembola: Effects on reproduction and stable isotope fractionation. Functional Ecology 94-102.

Schneider, K., Maraun, M., 2005. Feeding preferences among dark pigmented fungal taxa ("Dematiacea") indicate limited trophic niche differentiation of oribatid mites (Oribatida, Acari). Pedobiologia 49, 61-67.

Schneider, T., Keiblinger, K.M., Schmid, E., Sterflinger-Gleixner, K., Ellersdorfer, G., Roschitzki, B., Richter, A., Eberl, L., Zechmeister-Boltenstern, S., Riedel, K., 2012. 
Who is who in litter decomposition? Metaproteomics reveals major microbial players and their biogeochemical functions. The ISME Journal 6, 1749-1762.

Setälä, H., 2002. Sensitivity of ecosystem functioning to changes in trophic structure, functional group composition and species diversity in belowground food webs. Ecological Research 17, 207-215.

Setälä, H., Huhta, V., 1990. Evaluation of the soil fauna impact on decomposition in a simulated coniferous forest soil. Biology and Fertility of Soils 10, 163-169.

Soddy, F., 1922. The origins of the conceptions of isotopes. Nobel Lecture.

Sollins, P., Homann, P., Caldwell, B.A., 1996. Stabilization and destabilization of soil organic matter: Mechanisms and controls. Geoderma 74, 65-105.

Tavi, N.M., Martikainen, P.J., Lokko, K., Kontro, M., Wild, B., Richter, A., Biasi, C., 2013. Linking microbial community structure and allocation of plant-derived carbon in an organic agricultural soil using ${ }^{13} \mathrm{CO}_{2}$ pulse-chase labelling combined with ${ }^{13} \mathrm{C}$-PLFA profiling. Soil Biology \& Biochemistry 58, 207-215.

Tcherkez, G., Mahé, A., Hodges, M., $2011 .{ }^{12} \mathrm{C} /{ }^{13} \mathrm{C}$ fractionations in plant primary metabolism. Trends in Plant Science 16, 499-506.

Tilman, D., Balzer, C., Hill, J., Befort, B.L., 2011. Global food demand and the sustainable intensification of agriculture. Proceedings of the National Academy of Sciences of the United States of America 108, 20260-20264.

Van der Heijden, M.G.A., Bardgett, R.D., van Straalen, N.M., 2008. The unseen majority: Soil microbes as drivers of plant diversity and productivity in terrestrial ecosystems. Ecology Letters 11, 296-310.

Veall, N., Vetter, H., 1958. Radioisotope techniques in clinical research and diagnosis. Butterwoth and Co.Ltd.

Von Berg, K., Thies, C., Tscharntke, T., Scheu, S., 2010. Changes in herbivore control in arable fields by detrital subsidies depend on predator species and vary in space. Oecologia 163, 1033-1042.

Wardle, D.A., Nicholson, K.S., Bonner, K.I., Yeates, G.W., 1999. Effects of agricultural intensification on soil-associated arthropod population dynamics, community structure, diversity and temporal variability over a seven-year period. Soil Biology \& Biochemistry 31, 1691-1706. 


\section{General Introduction}

Wardle, D.A., Yeates, G.W., Watson, R.N., Nicholson, K.S., 1995. The detritus food-web and the diversity of soil fauna as indicators of disturbance regimes in agroecosystems. Plant and Soil 170, 35-43.

Wickman, F.E., 1952. Variations in the relative abundance of the carbon isotopes in plants. Geochimica et Cosmochimica Acta 2, 243-254. 
Chapter 2

\section{The Role of Shoot Residues vs. Crop Species FOR SOIL ARTHROPOD DIVERSITY AND ABUNDANCE of ARAble SYSTEMS}

Nicole Scheunemann, Mark Maraun, Stefan Scheu and Olaf Butenschoen

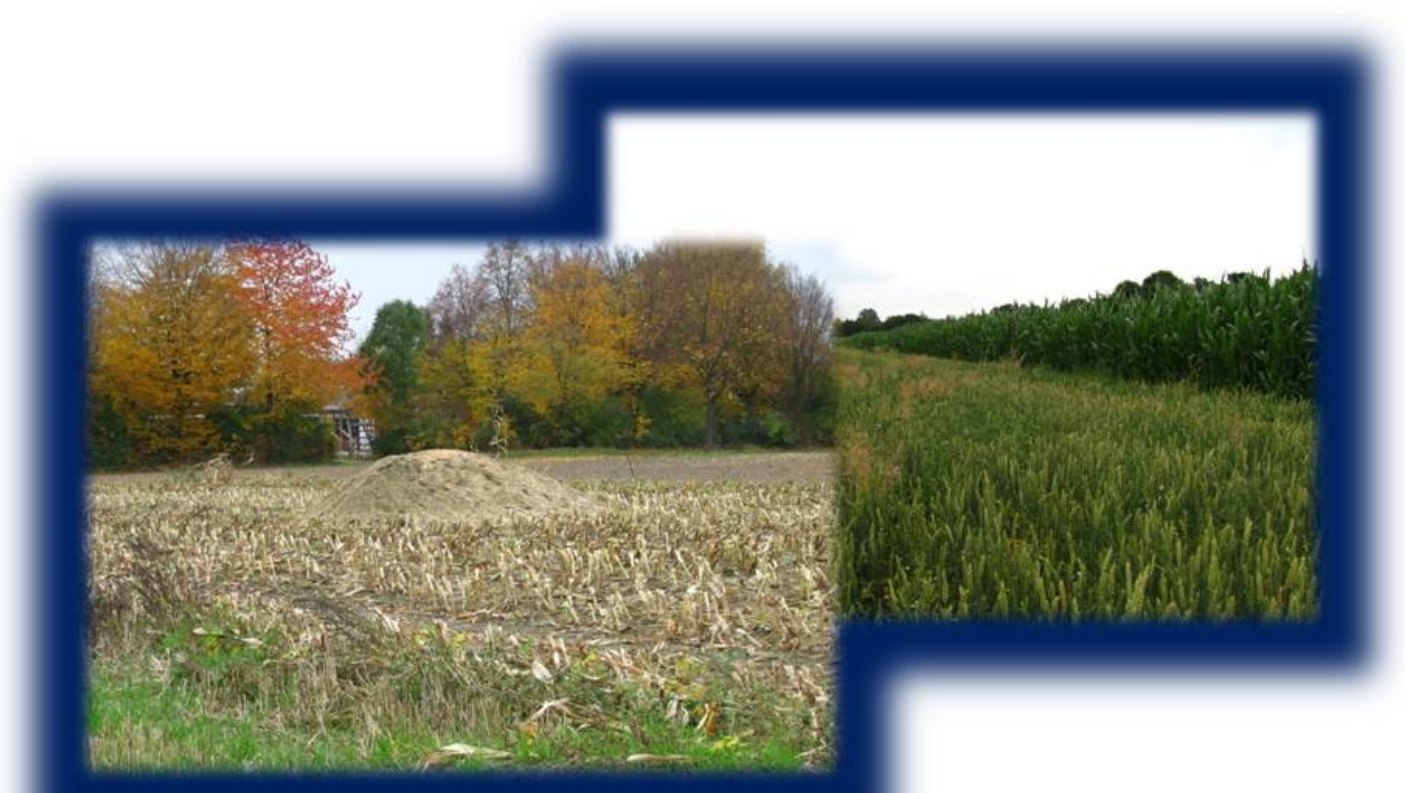

published in Soil Biology \& Biochemistry 81, 81-88. 


\begin{abstract}
Removal of crop residues has become common practice in arable systems, however, little is known about how soil arthropod communities change in response to reduced resource availability and habitat complexity associated with residue removal. We added maize residues to wheat and maize fields and investigated soil arthropod diversity and abundance over the period of one year. Residue addition did not affect the diversity and little affected the abundance of soil arthropods in wheat and maize fields with the latter being restricted to few taxonomic groups, suggesting that at least in the short-term soil arthropods benefit little from crop residue-mediated increase in food supply and habitat structure. Contrasting the minor effects of residue addition, densities of soil arthropods were much higher in wheat than in maize fields, presumably due to more dense and more continuous coverage by plants, and higher input of root residues. Furthermore, in wheat fields density of arthropods more strongly varied with season, presumably due to more pronounced pulses of root exudates and root residues entering the soil in wheat as compared to maize fields in summer and winter, respectively. Low density and little variation in densities of soil arthropods in maize fields reflect that environmental conditions and resource supply varied little with crop coverage and season. Overall, the results point to low importance of aboveground crop residues for soil arthropod communities and highlight that belowground plant resources, i.e. root exudates and root residues are the major driver of soil arthropod communities of arable systems. Thus, at least in short term removal of crop residues for e.g., biofuel production is likely to be of minor importance for soil arthropod communities. In contrast, changing crop species from wheat to maize markedly reduces the density of soil animals threatening the ecosystem functions they provide.
\end{abstract}

Keywords: agroecosystem, arthropods, maize, residues, soil food web, wheat 


\section{Introduction}

Currently, $40 \%$ of the terrestrial land area is used for agriculture and projections suggest that profound intensification will be needed to meet the demand for food and fibre of a growing human population (Foley et al., 2005; Tilman et al., 2011). Annually $3 \mathrm{Gt}$ of crop residues are produced globally, and typically they are left on the field to reduce soil erosion and to maintain soil organic carbon stocks and soil fertility (Michels et al., 1995; Wilhelm et al., 2004). However, increasing interest to mitigate global climate change has led to the practice of complete crop residue removal for biofuel production with potentially adverse environmental impacts (Bussière and Cellier, 1994). Importantly, the removal of crop residues may also impact soil biodiversity and impair key soil functions (Freibauer et al., 2004). Although there is evidence from previous studies that crop residue removal impact certain taxa including fungi (Karlen et al., 1994) and Lumbricidae (Karlen et al., 1994; Blanco-Canqui and Lal, 2007), understanding consequences for soil food web structure and functioning is limited.

Soils are inhabited by a large number of organisms, from unicellular microorganisms and protists to a variety of arthropods that interact in complex food webs and provide important services including carbon sequestration, recycling of nutrients and plant growth (Bardgett, 2005). Organic material derived from plants serves as basic resource of the soil food web, and carbon and nutrients mobilized by soil organisms during decomposition propagate to higher trophic levels (Moore et al., 2004; Ilieva-Makulec et al., 2006; Schneider et al., 2012). Soil arthropods, such as Lumbricidae, Diplopoda, Isopoda, Oribatida and Collembola, facilitate decomposition by removing litter from the soil surface and increasing leaf litter surface area for microbial attack (Bardgett et al., 2005; Chamberlain et al., 2006). Other soil arthropods, in particular soil micro-arthropods, benefit from litter inputs by feeding on saprotrophic microorganisms colonizing the litter materials (Ruess et al., 2007). Apart from serving as resource, plant residues also increase habitat structure, and favour the abundances of decomposers and arthropods of higher trophic levels (Halaj and Wise, 2002). In arable fields, removal of crop residues therefore is likely to detrimentally impact both habitat structure and resource availability of many soil organisms, resulting in simplified food webs of low diversity and abundance thereby impairing their services (Culman et al., 2010; Postma-Blaauw et al., 2010). 
Addition of plant residues to the soil has been shown to impact arthropod performance in a number of ecosystems; however, the response of soil arthropods is controversial (Sayer, 2006) and both positive (Axelsen and Kristensen, 2000; Hansen, 2000) and negative effects have been documented (Salamon et al., 2006), suggesting that effects are species and/or context specific. Moreover, recent studies in forest ecosystems suggest that root-derived carbon surpasses aboveground plant inputs in driving soil food webs (Pollierer et al., 2007; Eissfeller et al., 2013), whereas in arable soils little is known on the relative importance of above- and belowground plant inputs for soil food web structure and functioning.

Wheat (Triticum aestivum L.) and maize (Zea mays L.) are the two most important crop species and dominate arable fields in Central Europe (FAO Stat, 2014). Habitat conditions vary between these crop species. For example, important drivers of soil arthropod communities, such as plant density and growth rate, and soil humidity and plant cover (Lal, 1978; Filser, 1995), differ markedly between maize and wheat fields (Sharratt and McWilliams, 2005). Further, root structure and density also differ between wheat and maize, and this likely adds to differential impacts of wheat and maize on soil arthropod communities.

We added crop residues to wheat and maize fields, and analysed soil arthropod abundance and diversity over a period of one year aiming at investigating the role of aboveground and belowground plant inputs for soil arthropod communities throughout one crop cycle. Wheat and maize fields without crop residue addition served as control. We hypothesised that (1) the addition of crop residues increases abundance and diversity of soil arthropods by increasing habitat structure and food availability, but we expected this effect to vary (2) between wheat and maize fields due to plant specific effects on micro-environmental conditions, and (3) during the growing season due to changes of belowground resource availability. 


\section{Materials and Methods}

\section{Study site}

The study site is located in Holtensen in central Germany near Göttingen $\left(51^{\circ} 33^{\prime} \mathrm{N}\right.$, $9^{\circ} 53^{\prime} \mathrm{E}$ ) at $160 \mathrm{~m}$ a.s.l. The climate is temperate with a mean annual temperature of $8.7^{\circ} \mathrm{C}$ and a mean annual precipitation of $645 \mathrm{~mm}$. The soil is characterized as haplic luvisol. After decades of C3 crop cultivation, the crop was changed to maize in 2009 (plot size 24 $\times 240 \mathrm{~m}$ ) embedded into a field of winter wheat. In each wheat and maize field 10 plots of $24 \times 24 \mathrm{~m}$ were established next to each other; half of the maize and wheat plots received crop residues in autumn to establish four treatments: maize plants with $(\mathrm{M}+)$ and without (M-) crop residues, and wheat plants with $(\mathrm{W}+)$ and without $(\mathrm{W}-)$ crop residues. Before and after seeding, maize plots were fertilized with ammonium nitrate and diammonium phosphate, while wheat plots were fertilized once with granular sulphate-nitrate fertilizer before seeding and three times with urea solution after seeding. Further, at the start of the experiment, tillage practice was changed from deep tillage to chisel plough tillage to a depth of $12 \mathrm{~cm}$. In 2010, winter wheat was changed to summer wheat (sown in April) to improve comparability of growing seasons between wheat and maize (also sown in April). Further information on fertilizer application and management practice is given in Kramer et al. (2012). Wheat was harvested in August 2009 by cutting wheat plants $10 \mathrm{~cm}$ above the soil surface and removing them from the plots. After harvest of maize cobs in October 2009, maize plants were cut at a height of $10 \mathrm{~cm}$ above soil surface and shoots (without cobs) were hackled to a particle size of ca. $1 \mathrm{~cm}^{2}$. Hackled crop residues were added to the respective maize and wheat plots at an amount of $0.8 \mathrm{~kg}$

dry weight $\mathrm{m}^{-2}$ resembling the aboveground biomass of maize. Crop residues remained at the soil surface, and wheat and maize roots remained in the soil during winter and were tilled into the soil in spring 2010 prior to seeding of wheat and maize.

\section{Sampling and analyses}

Soil samples were taken at four dates, July 2009, two month after establishment of the experiment, September 2009, December 2009, six weeks after residue addition to the plots, and July 2010. The samplings in July, September and December referred to the 
maize growth periods of highest root exudation shortly before flowering, low root exudation before harvest and high input of root residues after harvest, respectively. At each sampling, two soil cores of $20 \mathrm{~cm}$ diameter and $10 \mathrm{~cm}$ depth were taken at each plot using a stainless steel soil corer. Soil arthropods were extracted by heat with the temperature gradually increasing from 25 to $55^{\circ} \mathrm{C}$ during 10 days (Kempson et al., 1963), transferred to saturated $\mathrm{NaCl}$ solution and kept at $-10{ }^{\circ} \mathrm{C}$ until further processing. Abundances of meso- and macrofauna were analysed using a dissecting microscope, which was also used for identification of macrofauna taxa, while mesofauna taxa were identified using a light microscope allowing 1000x magnification. Schaefer (2010) was used as standard key for macrofauna, while Hopkin (2007), Weigmann (2006) and Karg (1993) were used for identification of Collembola, Oribatida and Gamasida, respectively.

\section{Statistical analyses}

Soil arthropod abundances are given as number of individuals $\mathrm{m}^{-2} \pm$ standard error of the mean (SEM). The number of soil arthropod taxa per soil sample was determined and is further referred to as "diversity" and given as species number \pm SEM. To improve homogeneity of variances, data on diversity and abundance were $\log _{10}(x+1)$ transformed prior to statistical analyses. Effects of Sampling date (July 2009, September 2009, December 2009 and July 2010) and Crop species (wheat, maize) on diversity of taxonomic groups, and abundance of taxa and taxonomic groups were analysed by twofactorial analysis of variance (ANOVA), while three-factorial ANOVA was used to inspect effects of Sampling date (December 2009, July 2010), Crop species (wheat, maize) and Residue addition (with, without). In the latter, we focus on effects of Residue addition and it's interactions with Sampling date and Crop species. ANOVAs were followed by Tukey's HSD test for comparison of means (significance level at $p<0.05$ ).

Effects of Sampling date and Crop species at each sampling, as well as effects of Sampling date, Crop species and Residue addition on soil arthropod community composition after residue addition were inspected after reduction of the data-set to six dimensions by non-metric multidimensional scaling (NMDS with Bray-Curtis distance). In addition to two- and three-factorial ANOVAs, the NMDS reduced dataset was analysed for effects of Sampling date and Treatment $\left(\mathrm{W}_{-}, \mathrm{W}_{+}, \mathrm{M}_{-}, \mathrm{M}_{+}\right.$; including only sampling dates 
of December 2009 and July 2010) using discriminant function analysis (DFA). Canonical scores were presented in two-dimensional space; squared Mahalanobis distances between groups were calculated to inspect differences between Sampling dates and Treatments. Principal components analysis (PCA) was used to correlate species present in at least three samples with the factors Sampling date and Crop species separately for each sampling date, and with Sampling date, Crop species and Residue addition separately for the two sampling dates after addition of crop residues.

ANOVAs and DFA were performed using Statistica 10 (Statsoft Inc., Tulsa, USA), while NMDS and PCA were performed with Canoco 5 (Microcomputer Power Ithaca, USA).

\section{Results}

\section{Soil arthropod community structure}

A total of 112 taxa were recorded, including 45 taxa of mesofauna and 67 taxa of macrofauna. On average 29.1 taxa were present per plot. Mesofauna consisted of Collembola, Gamasida and Oribatida, which contributed $76.4 \pm 3.1 \%, 14.4 \pm 1.8 \%$ and 9.2 $\pm 2.1 \%$ to total mesofauna abundance across all samplings, respectively (Fig. 1). The most abundant taxonomic macrofauna groups were Diptera $(24.0 \pm 4.9 \%$ of total macrofauna across all sampling dates), Chilopoda (incl. Symphyla; $23.7 \pm 3.1 \%$ ), Diplopoda (18.3 \pm $2.5 \%)$, juvenile and adult Coleoptera $(15.0 \pm 1.7 \%$ and $10.1 \pm 2.0 \%$, respectively) and Aphidina (8.9 $\pm 3.7 \%$; Fig. 2). 


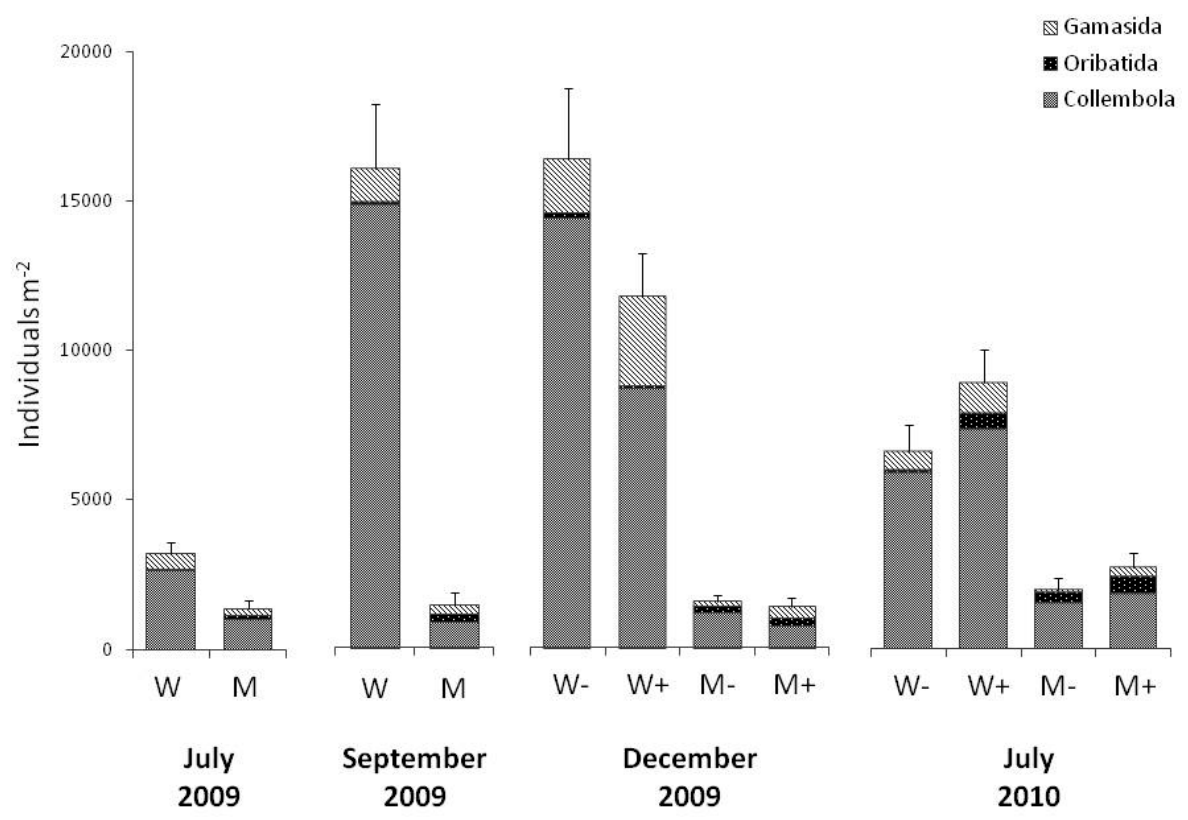

Figure 1: Abundances of mesofauna in wheat $(W)$ and maize fields $(M)$ as affected by residue addition (-, without; +, with) and season. Means \pm SEM.

December 2009

July

2010

Figure 2: Abundances of major groups of macrofauna in wheat (W) and maize fields (M) as affected by residue addition $(-$, without; + , with) and season. Means \pm SEM. Coleop juv=Coleoptera larvae, Coleop ad=adult Coleoptera 


\section{Seasonal variations}

Crop species was the most important factor explaining variations in soil arthropod abundance and diversity (Tables 1 and 2) across all sampling dates and taxa, with higher diversity and abundance in wheat than in maize plots. However, the beneficial effect of wheat on soil arthropod diversity and abundance changed during the growing season with differences in diversity being most pronounced in December 2009, while differences in soil arthropod abundance were less pronounced in July 2009 than at the other sampling dates. Supporting these results, PCA separated maize and wheat as well as taxa present at the maize plots from those at the wheat plots along the first axis, explaining $29.1 \%$ of the variation in soil arthropod community composition (Fig. 3a).

Sampling date was the second most important factor affecting soil arthropod diversity and abundance (Tables 1 and 2), with PCA separating July 2010 from the other sampling dates along the second axis, explaining $13.5 \%$ of the variation in soil arthropod community composition (Fig. 3a). Soil arthropod communities in September and December 2009 were more similar to each other than to those in July 2009. Sampling dates were also separated by DFA (Wilk's lambda=0.0116, $F_{18,156}=33.19$, $p<0.0001$; Fig. 4a), with soil arthropod community composition differing significantly between each of the sampling dates ( $p<0.0001$ for all possible pairs). The first axis (eigenvalue 6.25 ) separated soil arthropod communities according to season with December 2009 differing most from both July sampling dates, with September 2009 occupying an intermediate position. The second axis separated July 2010 from the other sampling dates (eigenvalue 5.49).

Collembola was the most abundant taxonomic group and comprised 26 species of which on average 8.2 species were present per plot. Collembola diversity was not significantly affected by Crop species, but by Sampling date and was highest at both July sampling dates (Table 2). On average, total abundance of Collembola was $5014 \pm 1346$ indiv. $\mathrm{m}^{-2}$ (Fig. S2), with the abundance in wheat markedly exceeding that in maize (Table 1), with lower abundance in July 2009 than at other sampling dates in both wheat and maize. Differences in Collembola abundances between wheat and maize were more pronounced in September and December 2009 than at both sampling dates in July. 


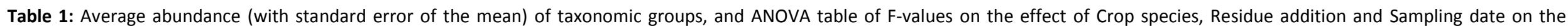
abundance of taxonomic groups; ${ }^{*} p<0.05,{ }^{* *} p<0.01,{ }^{* * *} p<0.001$.

\begin{tabular}{|c|c|c|c|c|c|c|c|c|c|c|c|c|}
\hline & \multirow[b]{2}{*}{$\begin{array}{c}\text { Average } \\
\text { abun- } \\
\text { dance } \\
\text { [indiv. } \\
\mathrm{m}^{-2} \text { ] }\end{array}$} & \multirow[b]{2}{*}{ SEM } & \multicolumn{3}{|c|}{ all sampling dates } & \multicolumn{7}{|c|}{ December 2009 and July 2010 (after residue addition) } \\
\hline & & & $\begin{array}{c}\text { Sampling } \\
\text { date }\end{array}$ & $\begin{array}{c}\text { Crop } \\
\text { species }\end{array}$ & $\begin{array}{c}\text { Sampling } \\
\text { date } \\
\times \\
\text { Crop species } \\
\\
F_{3,56} \\
\end{array}$ & $\begin{array}{c}\text { Sampling } \\
\text { date }\end{array}$ & Crop species & $\begin{array}{c}\text { Residue } \\
\text { addition } \\
\\
F_{1,24} \\
\end{array}$ & $\begin{array}{c}\text { Sampling } \\
\text { date } \\
\times \\
\text { Crop species } \\
\\
F_{1,24} \\
\end{array}$ & $\begin{array}{c}\text { Sampling date } \\
\times \\
\text { Residue } \\
\text { addition } \\
\\
F_{1,24} \\
\end{array}$ & $\begin{array}{c}\text { Crop species } \\
\times \\
\text { Residue } \\
\text { addition } \\
\\
\mathbf{F}_{1,24} \\
\end{array}$ & $\begin{array}{c}\text { Sampling date } \\
\times \\
\text { Crop species } \\
\times \\
\text { Residue } \\
\text { addition } \\
\\
F_{1,24}\end{array}$ \\
\hline all & - & - & $144.74^{* * *}$ & $68.63^{* * *}$ & $4.60 * * *$ & $53.56 * * *$ & $36.95 * * *$ & 1.11 & $4.66^{* *}$ & 2.21 & 0.86 & 0.87 \\
\hline Collembola & 5013.8 & 26.8 & $10.57 * * *$ & $328.75 * * *$ & $17.99 * * *$ & 0.05 & $187.20 * * *$ & 0.79 & $14.88 * * *$ & $6.96 *$ & 0.01 & 0.00 \\
\hline Oribatida & 214.2 & 4.4 & $6.05 * * *$ & $4.90 *$ & 0.22 & $6.89 *$ & 1.25 & 0.37 & 0.00 & 3.81 & 0.22 & 1.02 \\
\hline Gamasina & 726.5 & 102.0 & $5.12 * *$ & $72.80 * * *$ & $3.35 *$ & $14.75 * * *$ & $82.73 * * *$ & $9.19 * *$ & 2.60 & 0.05 & 0.91 & 0.33 \\
\hline Coleoptera adult & 99.8 & 1.8 & 0.68 & $89.24 * * *$ & 1.38 & 1.65 & $73.66 * * *$ & 0.62 & 0.38 & 0.00 & 0.27 & 0.08 \\
\hline Coleoptera larvae & 131.7 & 1.4 & $13.08 * * *$ & $30.14 * * *$ & $3.58 *$ & $16.38 * * *$ & $20.73 * * *$ & 0.88 & 0.42 & 1.85 & 1.18 & 0.13 \\
\hline Diptera & 187.0 & 55.5 & $2.92 *$ & 0.41 & 0.63 & $13.60^{* *}$ & 2.11 & 1.86 & 0.01 & 3.63 & 0.98 & 1.86 \\
\hline Aphidinae & 241.1 & 82.2 & $13.42 * * *$ & $17.88^{* * *}$ & $5.09 * *$ & $32.27 * * *$ & $19.24 * * *$ & 1.51 & $11.24 * *$ & 0.60 & 0.83 & 0.21 \\
\hline Chilopoda+Symphyla & 192.7 & 27.5 & $21.73 * * *$ & 0.89 & $3.20 *$ & $56.07 * * *$ & $6.27^{*}$ & 0.01 & 1.60 & 0.43 & 3.80 & 0.01 \\
\hline Diplopoda & 155.8 & 19.1 & $9.45 * * *$ & 3.71 & 1.79 & $22.35 * * *$ & $8.98^{* *}$ & 1.65 & 1.32 & 0.37 & 1.53 & 1.06 \\
\hline
\end{tabular}




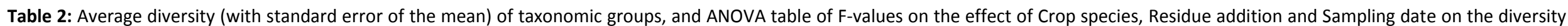
of taxonomic groups; ${ }^{*} p<0.05,{ }^{* *} p<0.01,{ }^{* * *} p<0.001$.

\begin{tabular}{|c|c|c|c|c|c|c|c|c|c|c|c|c|}
\hline & \multirow[b]{2}{*}{$\begin{array}{c}\text { Average } \\
\text { diversity } \\
\text { [number } \\
\text { of } \\
\text { species] }\end{array}$} & \multirow[b]{2}{*}{ SEM } & \multicolumn{3}{|c|}{ all sampling dates } & \multicolumn{7}{|c|}{ December 2009 and July 2010 (after residue addition) } \\
\hline & & & $\begin{array}{c}\text { Sampling } \\
\text { date }\end{array}$ & $\begin{array}{c}\text { Crop } \\
\text { species } \\
\\
\mathrm{F}_{1,56} \\
\end{array}$ & $\begin{array}{c}\text { Sampling } \\
\text { date } \\
\times \\
\text { Crop species } \\
\\
\mathrm{F}_{3,56} \\
\end{array}$ & $\begin{array}{c}\text { Sampling } \\
\text { date }\end{array}$ & Crop species & $\begin{array}{c}\text { Residue } \\
\text { addition } \\
\mathrm{F}_{1,24} \\
\end{array}$ & $\begin{array}{c}\text { Sampling } \\
\text { date } \\
\times \\
\text { Crop species } \\
\\
\mathrm{F}_{1,24} \\
\end{array}$ & $\begin{array}{c}\text { Sampling } \\
\text { date } \\
\times \\
\text { Residue } \\
\text { addition } \\
\\
\mathrm{F}_{1,24} \\
\end{array}$ & $\begin{array}{c}\text { Crop species } \\
\times \\
\text { Residue } \\
\text { addition } \\
\\
\mathrm{F}_{1,24} \\
\end{array}$ & $\begin{array}{c}\text { Sampling date } \\
\times \\
\text { Crop species } \\
\times \\
\text { Residue } \\
\text { addition } \\
\\
\mathrm{F}_{1,24} \\
\end{array}$ \\
\hline all & 29.1 & 0.8 & $10.36 * * *$ & $59.87 * * *$ & $7.41 * * *$ & $14.80 * * *$ & $70.77 * * *$ & 0.63 & 3.69 & 1.12 & 1.06 & 2.81 \\
\hline Collembola & 8.2 & 0.3 & $4.79 * *$ & 3.22 & 0.60 & 0.17 & 3.98 & 0.08 & 0.04 & 1.20 & 0.32 & $4.42 *$ \\
\hline Oribatida & 1.8 & 0.1 & $4.07^{*}$ & 0.00 & 0.41 & 1.03 & 0.90 & 0.22 & 0.14 & 3.22 & 0.14 & 2.09 \\
\hline Gamasina & 5.1 & 0.2 & $3.59 *$ & $19.47 * * *$ & $3.88 *$ & 2.35 & $33.60 * * *$ & 3.29 & 0.00 & 2.64 & 0.57 & 0.89 \\
\hline Coleoptera adult & 2.7 & 0.2 & 2.04 & $47.88 * * *$ & $6.34 * * *$ & $6.04 *$ & $55.61 * * *$ & 2.19 & 7.01* & 0.11 & 1.09 & 0.02 \\
\hline Coleoptera larvae & 2.2 & 0.1 & $9.99 * * *$ & $34.23 * * *$ & 1.36 & 2.19 & $28.12 * * *$ & 0.64 & 1.92 & 1.48 & 0.50 & 1.26 \\
\hline Diptera & 1.9 & 0.1 & $2.90 *$ & 0.42 & 0.99 & $4.26 *$ & 0.36 & 1.50 & 0.06 & 1.17 & $4.26 *$ & 0.06 \\
\hline Aphidinae & - & & - & - & - & - & - & - & - & - & - & - \\
\hline Chilopoda+Symphyla & 1.8 & 0.1 & $26.44 * * *$ & $5.22 *$ & 0.55 & $58.83 * * *$ & 1.96 & 0.33 & 0.03 & 0.98 & 0.98 & 0.33 \\
\hline Diplopoda & 2.6 & 0.1 & $3.85 *$ & $6.69 *$ & $2.84 *$ & $9.98 * *$ & $12.82 * *$ & 0.04 & 0.24 & 0.83 & 0.24 & 0.05 \\
\hline
\end{tabular}


Higher abundance in wheat than maize, and in September and December 2009 than at both July sampling dates was true for most Collembola species, with the interaction between Crop species and Sampling date being significant in most cases (Table S1). For instance, the most abundant Collembola species in wheat plots, Isotoma viridis, was strongly affected by Crop species, resulting in higher abundances in wheat than maize plots, particularly in September and December 2009. In contrast, the abundance of the most abundant species in maize, Protaphorura armata, was similar in wheat and maize plots (Table S1, Fig. S2).

(a)



(b)

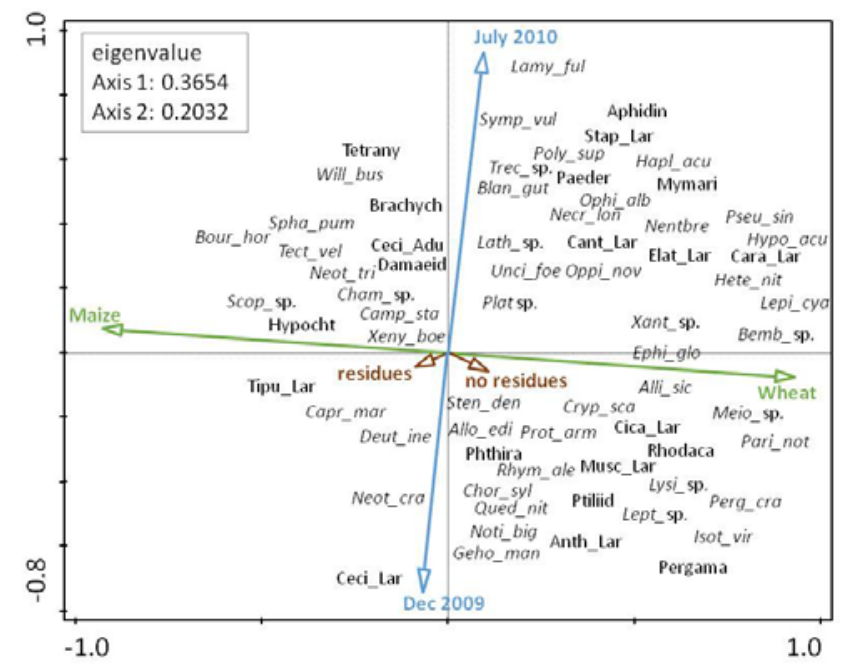

Figure 3: PCA of the abundance of soil arthropod taxa (for full taxa names see Table S1). Species that were present in less than three samples were excluded from the analysis. (a) Effects of Sampling date and Crop species at all sampling dates, (b) effects of Sampling date, Crop species and Residue addition in December 2009 and July 2010. Sampling date, Crop species and Residue addition were treated as independent variables and are given in bold letters. 
(a)

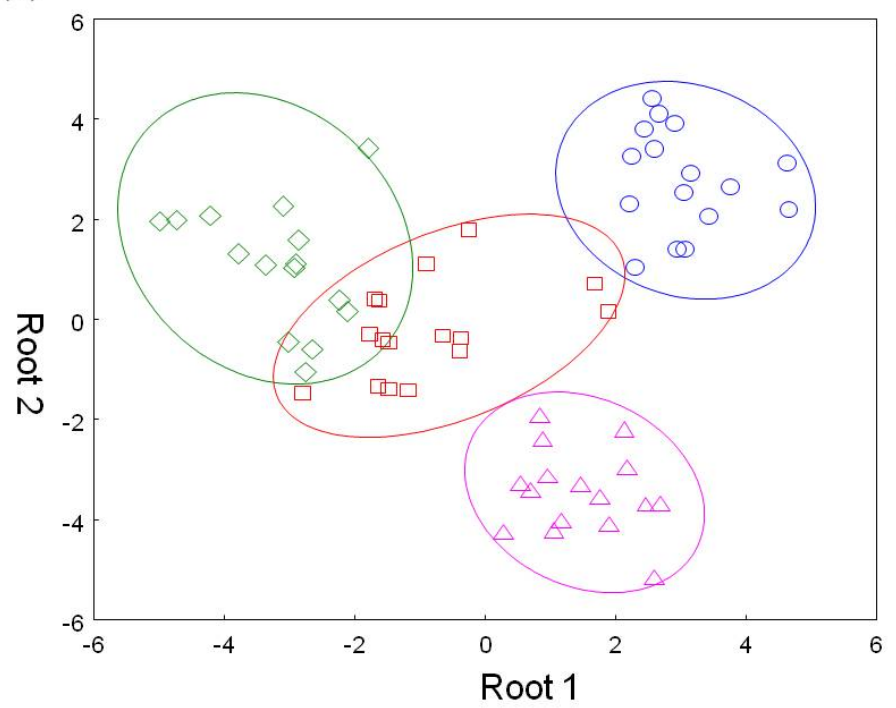

- July 2009

$\square$ September 2009

December 2009

$\triangle$ July 2010

(b)

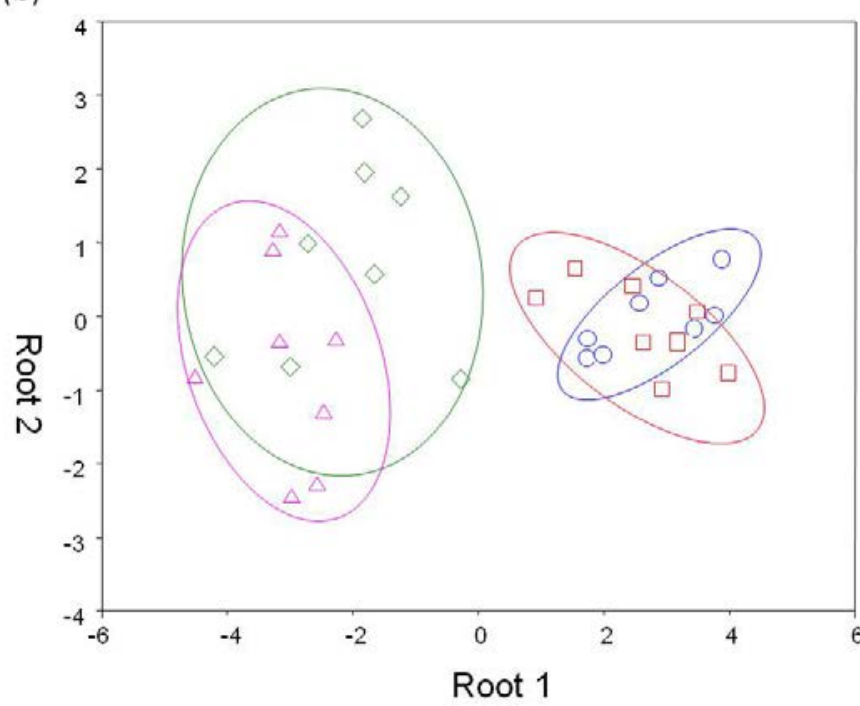

W +

$\square W-$

จ +

$\triangle M-$

Figure 4: DFA of the soil arthropod community based on the NMDA reduced data-set as affected by (a) Sampling date, and (b) Crop species (W, wheat; M, maize) and Residue addition (-, without; +, with) at the sampling dates December 2009 and July 2010. Ellipses represent confidence ranges at $p=0.05$.

Oribatida comprised 11 taxa of which on average 1.8 taxa were present per plot. Oribatida diversity was highest in July 2010, but did not vary significantly with Crop species or the interaction of Crop species and Sampling date (Table 2). The average total abundance of Oribatida was $214 \pm 34$ indiv. $\mathrm{m}^{-2}$ (Fig. S3) and was generally higher in maize than wheat (Table 1). Similar to diversity, average abundance was higher in July 2010 than 
July and September 2009, but the effect was independent of Crop species. The most abundant Oribatida species were Tectocepheus velatus and Oppiella nova reaching maximum densities in July 2010, with $T$. velatus being more abundant in maize and $O$. nova being more abundant in wheat (Table S1).

Gamasida comprised 8 taxa of which on average 5.1 taxa were present per plot. Crop species significantly affected Gamasida diversity (Table 2), with more species in wheat than maize plots. Gamasida diversity was higher in December 2009 than July 2009, with the difference between maize and wheat in September 2009 being less pronounced than at the other sampling dates. The average abundance of Gamasida was $726 \pm 102$ indiv. $\mathrm{m}^{-2}$ (Fig. S4) and was higher in December 2009 than at both sampling dates in July. Moreover, Gamasida abundance differed between crop species and was higher in wheat than maize plots (Table 1), particularly in December 2009 and July 2010. Similar to total Gamasida, the abundance of most Gamasida species significantly varied with Crop species, with higher abundances in wheat than in maize plots, e.g. in the most abundant species Hypoaspis aculeifer, Alliphis siculus and Pergamasus crassipes. Further, abundances of most species varied across sampling dates, with higher abundances in December 2009 than July 2009, while abundances in July 2010 and September 2009 were intermediate in most species (Table S1).

Of the 35 taxa of adult Coleoptera, on average 2.7 were present per plot. Coleoptera diversity was significantly higher in wheat as compared to maize (Table 2) and was much higher in December 2009 than at the other sampling dates. On average the abundance of adult Coleoptera was $100 \pm 22$ indiv. $\mathrm{m}^{-2}$ (Fig. S5), but it varied with Crop species (Table 1), being higher in wheat than in maize across all sampling dates. However, effects of Crop species and Sampling date varied at the level of Coleoptera taxa, but consistently dominant taxa were more abundant in wheat than in maize, e.g., Trechus sp. and Bembidion sp. (Table S1).

In total, five taxa of Coleoptera larvae were identified with on average 2.2 taxa per plot. Diversity of Coleoptera larvae was higher in wheat than maize (Table 2), and differences between maize and wheat were similar at each of the sampling dates. Generally, diversity was highest in December 2009. The average abundance of Coleoptera larvae was $132 \pm 21$ indiv. $\mathrm{m}^{-2}$ (Fig. S6) and varied with crop species, with higher 
abundances in wheat than maize (Table 1). The difference between crop species was less pronounced in September 2009 than at the other sampling dates, and total abundance was highest in July 2010. Most taxa of Coleoptera larvae were more abundant in wheat than maize, except Staphylinidae larvae which were not affected by Crop species (Table S1).

Four taxa of Diptera were identified of which three were juvenile. Diversity was highest in December 2009 (Table 2), independent of Crop species. The average total abundance of Diptera was $187 \pm 56$ indiv. $\mathrm{m}^{-2}$ (Fig. S7) and did not significantly differ between wheat and maize (Table 1). However, independent of Crop species, Diptera abundance was significantly higher in December 2009 than in July 2010. Each taxon, except Tipulidae larvae, varied significantly with Sampling date, but only Muscidae larvae were more abundant in wheat than in maize (Table S1).

Aphidina were not identified at higher taxonomic resolution. The average abundance of Aphidina was $190 \pm 71$ indiv. $\mathrm{m}^{-2}$ and was higher in wheat than maize (Table 1), particularly in September 2009 and July 2010. Further, the abundance of Aphidina varied with Sampling date, with higher abundance in July 2010 than in the other samplings in both wheat and maize plots.

Due to low species numbers, we summed up Chilopoda (2 taxa) and Symphyla (1 taxon). The diversity of this group was positively affected by wheat (Table 2 ) and this was consistent across all sampling dates. Diversity was lowest in December 2009 due to the absence of Lamyctes fulvicornis in both wheat and maize. The average abundance of Chilopoda+Symphyla was $193 \pm 27$ indiv. $\mathrm{m}^{-2}$ (Fig. S8) and did not differ significantly between maize and wheat (Table 1). However, the abundance of Chilopoda+Symphyla significantly varied with Sampling date, with lower abundances in December 2009 than at the other sampling dates. Both dominant species Symphylella vulgaris and L. fulvicornis were most abundant in July 2010 (Table S1).

Of the seven Diplopoda species, on average 2.6 were present per plot. Diversity of Diplopoda significantly varied with Crop species (Table 2) and was higher in wheat than maize at each of the sampling dates. Diversity was highest in July 2010 and lowest in December 2009. The average abundance of Diplopoda was $156 \pm 19$ indiv. $\mathrm{m}^{-2}$ (Fig. S9) and was not significantly affected by Crop species (Table 1), but it was higher in July 2010 
and September 2009 than in July and December 2009. The abundance of the dominant species of Diplopoda significantly varied with Sampling date being most abundant in July 2010, but only the abundance of Polydesmus superus varied with Crop species being more abundant in wheat than in maize (Table S1).

\section{Variation due to crop residue addition}

After addition of crop residues in autumn 2009, Crop species still remained the most important factor affecting the community structure of soil arthropods, with generally higher diversity and abundances in wheat than in maize and separation of taxa along the first PCA axis (eigenvalue 0.365; Fig. 3b). Also, DFA separated treatments after crop residue addition (Wilk's lambda $=0.0805, F_{18,65}=5.23, p<0.0001$ ), with Crop species explaining $90.8 \%$ of the variance in species data (eigenvalue of axis 1 of 4.69; Fig. 4b). Notably, crop residues neither affected diversity nor abundance of soil arthropods (Table 1 and 2), and there was no interaction of Residue addition and Sampling date and/or Crop species. Consequently, PCA and DFA did not separate taxa from plots with crop residues from those from plots of the respective plant without crop residues (Fig. 3b, 4a).

In contrast to total soil arthropods, crop residues affected Collembola abundance, but the effect varied between sampling dates (Table 1); crop residues slightly reduced Collembola abundance in December 2009, but slightly increased Collembola abundance in July 2010 with the effects being independent of crop species (Fig. S2). Also, Collembola diversity varied with Residue addition, but the effect depended on Sampling date and Crop species; the number of species increased from maize plots without crop residues in December 2009 to wheat plots without crop residues in December 2009, with the other sampling dates and treatments being intermediate. In contrast to Collembola, Residue addition did not affect diversity and abundance of Oribatida (Table 1 and 2), but the abundance of Gamasida increased with crop residues (Table 2). Among Gamasida species Alliphis siculus was significantly more abundant in plots with crop residues, while Nenteria breviunguiculata tended to be more abundant in plots with crop residues (Table S1). Crop residues neither affected diversity nor abundance of adult Coleoptera, although abundances of Bembidion sp., Lathrobium sp. and Quedius nitipennis tended to be increased by crop residues. Abundance and diversity of juvenile Coleoptera were not 
affected by crop residues, but Staphylinidae larvae were slightly more abundant in plots with crop residues in December 2009. Cecidomyiidae (Diptera) benefitted from crop residues (Table S1), but Diptera diversity was not significantly affected by Residue addition. However, the effect of Residue addition varied with Crop species, and diversity of Diptera increased in maize, but remained constant with Residue addition in wheat. Crop residues neither affected the abundance of Aphidina nor abundance and diversity of Chilopoda+Symphyla and Diplopoda (Table 1 and 2).

\section{Discussion}

\section{Crop residues}

In contrast to our first hypothesis, the addition of crop residues did not affect the abundance or diversity of most taxonomic groups. Crop residues remained on the soil surface during winter, and increased both habitat structure and resource availability (Sayer, 2006), whereas in spring 2010, after being incorporated into the soil, crop residues may have rather served as resource for the soil microbial community. Indeed, at our study site crop residue addition significantly increased microbial biomass (Kramer et al., 2013), and the density of amoebae and nematodes (Scharroba et al., 2012). However, despite these positive effects on potential prey organisms, residue addition little affected abundance and diversity of higher trophic levels of meso- and macrofauna, suggesting that crop residues are of little importance for structuring soil arthropod communities in arable ecosystems. Possibly, the positive effect of additional resources on higher trophic levels would have been more pronounced after several seasons of residue addition, but the lack of significant effects after one year indicates that limitation by litter resources is of little importance for soil arthropods in arable systems.

Although residue addition in general did not affect soil animal diversity and only slightly increased soil animal abundances, single taxa were beneficially affected by crop residues. For example, the abundance of Gamasida significantly increased by the addition of crop residues in December 2009 as well as July 2010. One of the most abundant Gamasida species in the present study, A. siculus, is known to prey on nematodes (Koehler, 1997) and therefore presumably benefitted from increased abundance of 
nematodes in response to addition of crop residues (Scharroba et al., 2012). Also, the abundance of Collembola was slightly increased by residue addition, but only in July 2010, suggesting that they may have benefitted from higher abundances of saprotrophic microorganisms and nematodes after the incorporation of crop residues into the soil (Read et al., 2006; Heidemann et al., 2014). Further, the abundance of Oribatida and Diptera also slightly increased with crop residue addition, but in Diptera the effect was restricted to December 2009. As the larvae of most Diptera at the field site were saprophagous (Nielsen and Nielsen, 2002), the slightly higher abundance of Diptera likely was related to direct feeding on crop residues at early stages of decomposition in winter. The abundance of the remaining soil arthropods did not respond significantly to crop residues. Surprisingly, even the abundance of Diplopoda, typical primary decomposers (Semenyuk and Tiunov, 2011), remained unaffected. This suggests that at least in arable ecosystems Diplopoda rely little on aboveground plant inputs, but rather on belowground root inputs (Crowther et al., 2011). Overall, the results underline results of litter manipulation studies in forest ecosystems (David et al., 1991; Salamon et al., 2006), suggesting that leaf residues little impact soil arthropod communities in both forests and arable systems (Pollierer et al., 2007; Kaiser et al., 2010; Eissfeller et al., 2013).

\section{Crop species}

In contrast to crop residue addition, abundance and diversity of soil arthropods strongly varied with crop species, documenting that soil arthropod communities are structured mainly by crop species rather than residue addition. The high abundance of soil arthropods in wheat as compared to maize likely was related to high resource availability and more complex habitat structure in wheat, reinforcing previous findings (Scheunemann et al., 2010). Higher density of wheat plants likely improved microenvironmental conditions (Kramer et al., 2013) and availability of root derived resources, beneficially affecting soil arthropods (Honek and Jarosik, 2000). The more pronounced beneficial effect of wheat in winter likely was due to the input of dead roots of wheat comprising a more branched and more spatially extended root system as compared to maize. Further, wheat seedlings emerging from grains lost during harvest may have provided additional root derived resources (Axelsen and Kristensen, 2000). The beneficial 
effect of root derived resources to soil arthropods in winter underlines the importance of easily available resources for soil animal food webs of arable systems contrasting soil organic matter originating from crop residues of previous years (Scheunemann et al., 2010).

The lack of significant crop residue effects on soil arthropods in maize presumably was due to the generally low availability of resources and harsh environmental conditions across seasons. As indicated by increased ratio between euedaphic (e.g., P. armata) and epedaphic Collembola species (e.g., I. viridis), adverse environmental conditions in maize plots in particular affected epedaphic species restricting effects of crop residue addition.

\section{Season}

In contrast to our third hypothesis, and in accordance to the overall poor importance of crop residues for soil arthropods, crop residue effects varied little with season. Only the response of Collembola abundances to crop residue addition varied at different samplings, but the responses were slight. Collembola abundance slightly increased with crop residue addition in July 2010, presumably due to increased availability of microbial and nematode prey. In contrast, Collembola abundance slightly decreased with crop residue addition in December 2009, potentially due to increased top-down control by predators. For example, abundance of Bembidion sp., Lathrobium sp. and Quedius nitipennis tended to increase with crop residue addition (cf. Eitzinger and Traugott, 2011).

Abundance and diversity of most taxonomic groups of soil arthropods increased from July 2009 to July 2010, independent of crop residue addition. Presumably, this was due to changes from deep tillage before 2009 to shallow chisel plough tillage in 2009 (Holland and Luff, 2000; Postma-Blaauw et al., 2010). The increase in abundance of arthropod taxa was particularly pronounced in wheat plots suggesting that reduced disturbance due to shallow chisel plough allowed more extensive exploitation of root derived resources of wheat by soil invertebrates.

Generally, in contrast to maize, soil arthropod abundances in wheat markedly varied between sampling dates, suggesting more pronounced changes in the availability of resources in wheat as compared to maize fields (Hamlen et al., 1972). In July 2009 and July 2010 low soil humidity may have contributed to low abundance of soil arthropods, 
which are known to sensitively respond to changes in soil moisture (Alvarez et al., 1999). Further, in winter, the presence of wheat seedlings may have beneficially affected soil arthropods (see above; Saitoh et al., 2013).

\section{Conclusion}

Our results extend findings from forest ecosystems, suggesting that also in arable systems, aboveground crop residue input is of little importance for most soil arthropods. Within the one-year duration of the experiment, crop residue addition little affected soil arthropod communities both across seasons and crop species, pointing to the overriding importance of belowground plant resources, i.e. root exudates and root residues, in structuring soil arthropod communities in arable systems. Thus, removal of crop residues for e.g., biofuel production is likely to little affect soil arthropod communities at least in the short term. In contrast, changing crop species from wheat to maize markedly reduces the density of soil animals threatening the ecosystem functions they provide.

\section{Acknowledgements}

We like to thank all the student helpers for their work during samplings, maize harvest, and residue addition. Further, Bernhard Klarner and Verena Eißfeller helped with the identification of Gamasida and Oribatida, respectively. Financial support was provided by

the German Research Foundation (DFG) within the Research Unit "Carbon flow in belowground food webs assessed by isotope tracers" (FOR 918).

\section{References}

Alvarez, T., Frampton, G.K., Goulson, D., 1999. The effects of drought upon epigeal Collembola from arable soils. Agricultural and Forest Entomology 1, 243-248.

Axelsen, J.A., Kristensen, K.T., 2000. Collembola and mites in plots fertilised with different types of green manure. Pedobiologia 44, 556-566. 
Bardgett, R.D., 2005. The biology of soil: A community and ecosystem approach, 1st ed. Oxford University Press, Oxford.

Bardgett, R.D., Bowman, W.D., Kaufmann, R., Schmidt, S.K., 2005. A temporal approach to linking aboveground and belowground ecology. Trends in Ecology \& Evolution 20, 634-641.

Blanco-Canqui, H., Lal, R., 2007. Soil and crop response to harvesting corn residues for biofuel production. Geoderma 141, 355-362.

Bussière, F., Cellier, P., 1994. Modification of the soil temperature and water content regimes by a crop residue mulch: Experiment and modelling. Agricultural and Forest Meteorology 68, 1-28.

Chamberlain, P.M., Mcnamara, N., Chaplow, J., Stott, A.W., Black, H.I.J., 2006. Translocation of surface litter carbon into soil by Collembola. Soil Biology \& Biochemistry 38, 2655-2664.

Crowther, T.W., Boddy, L., Jones, T.H., 2011. Species-specific effects of soil fauna on fungal foraging and decomposition. Oecologia 167, 535-545.

Culman, S.W., Young-Mathews, A., Hollander, A.D., Ferris, H., Sanchez-Moreno, S., O'Geen, A.T., Jackson, L.E., 2010. Biodiversity is associated with indicators of soil ecosystem functions over a landscape gradient of agricultural intensification. Landscape Ecology 25, 1333-1348.

David, J.-F., Ponge, J.-F., Arpin, P., Vannier, G., 1991. Reactions of the macrofauna of a forest mull to experimental perturbations of litter supply. Oikos 61, 316-326.

Eissfeller, V., Beyer, F., Valtanen, K., Hertel, D., Maraun, M., Polle, A., Scheu, S., 2013. Incorporation of plant carbon and microbial nitrogen into the rhizosphere food web of beech and ash. Soil Biology \& Biochemistry 62, 76-81.

Eitzinger, B., Traugott, M., 2011. Which prey sustains cold-adapted invertebrate generalist predators in arable land? Examining prey choices by molecular gut-content analysis. Journal of Applied Ecology 48, 591-599.

FAO Stat, 2014. Food and Agriculture Organisation of the United Nations [WWW Document]. http://faostat3.fao.org/faostat-gateway/go/to/home/E.

Filser, J., 1995. The effect of green manure on the distribution of collembola in a permanent row crop. Biology and Fertility of Soils 19, 303-308. 
Foley, J.A., Defries, R., Asner, G.P., Barford, C., Bonan, G.B., Carpenter, S.R., Chapin, F.S., Coe, M.T., Daily, G.C., Gibbs, H.K., Helkowski, J.H., Holloway, T., Howard, E.A., Kucharik, C.J., Monfreda, C., Patz, J.A., Prentice, I.C., Ramankutty, N., Snyder, P.K., 2005. Global consequences of land use. Science 309, 570-574.

Freibauer, A., Rounsevell, M.D., Smith, P., Verhagen, J., 2004. Carbon sequestration in the agricultural soils of Europe. Geoderma 122, 1-23.

Halaj, J., Wise, D.H., 2002. Impact of a detrital subsidy on trophic cascades in a terrestrial grazing food web. Ecology 83, 3141-3151.

Hamlen, R.A., Lukezic, F.L., Bloom, J.R., 1972. Influence of age and stage of development on the neutral carbohydrate components in root exudates from alfalfa plants grown in a gnotobiotic environment. Canadian Journal of Plant Science 52, 633-642.

Hansen, R.A., 2000. Effects of habitat complexity and composition on a diverse litter microarthropod assemblage. Ecology 81, 1120-1132.

Heidemann, K., Hennies, A., Schakowske, J., Blumenberg, L., Ruess, L., Scheu, S., Maraun, M., 2014. Free-living nematodes as prey for higher trophic levels of forest soil food webs. Oikos 123, 1199-1211.

Holland, J.M., Luff, M.L., 2000. The effects of agricultural practices on Carabidae in temperate agroecosystems. Integrated Pest Management Reviews 5, 109-129.

Honek, A., Jarosik, V., 2000. The role of crop density, seed and aphid presence in diversification of field communities of Carabidae (Coleoptera). European Journal of Entomology 97, 517-525.

Hopkin, S.P., 2007. A Key to the Collembola (Springtails) of Britain and Ireland, 1st ed. Field Studies Council.

Ilieva-Makulec, K., Olejniczak, I., Szanser, M., 2006. Response of soil micro- and mesofauna to diversity and quality of plant litter. European Journal of Soil Biology $42,244-249$.

Kaiser, C., Koranda, M., Kitzler, B., Fuchslueger, L., Schnecker, J., Schweiger, P., Rasche, F., Zechmeister-Boltenstern, S., Sessitsch, A., Richter, A., 2010. Belowground carbon allocation by trees drives seasonal patterns of extracellular enzyme activities by altering microbial community composition in a beech forest soil. New Phytologist $187,843-858$. 
Karg, W., 1993. Die Tierwelt Deutschlands 59 - Raubmilben, 2nd ed. Gustav Fischer Verlag, Jena-Stuttgart-New York.

Karlen, D.L., Wollenhaupt, N.C., Erbach, D.C., Berry, E.C., Swan, J.B., Eash, N.S., Jordahl, J.L., 1994. Crop residue effects on soil quality following 10 years of no-till corn. Soil and Tillage Research 31, 149-167.

Kempson, D., Lloyd, M., Ghelardi, M., 1963. A new extractor for woodland litter. Pedobiologia 3, 1-21.

Koehler, H.H., 1997. Mesostigmata (Gamasina, Uropodina), efficient predators in agroecosystems. Agriculture, Ecosystems \& Environment 62, 105-117.

Kramer, S., Marhan, S., Haslwimmer, H., Ruess, L., Kandeler, E., 2013. Temporal variation in surface and subsoil abundance and function of the soil microbial community in an arable soil. Soil Biology \& Biochemistry 61, 76-85.

Kramer, S., Marhan, S., Ruess, L., Armbruster, W., Butenschoen, O., Haslwimmer, H., Kuzyakov, Y., Pausch, J., Scheunemann, N., Schoene, J., Schmalwasser, A., Totsche, K.U., Walker, F., Scheu, S., Kandeler, E., 2012. Carbon flow into microbial and fungal biomass as a basis for the belowground food web of agroecosystems. Pedobiologia $55,111-119$.

Lal, R., 1978. Influence of within- and between-row mulching on soil temperature, soil moisture, root development and yield of maize (Zea mays L.) in a tropical soil. Field Crop Research 1, 127-139.

Michels, K., Sivakumar, M.V.K., Allison, B.E., 1995. Wind erosion control using crop residue I. Effects on soil flux and soil properties. Field Crop Research 40, 101-110.

Moore, J.C., Berlow, E.L., Coleman, D.C., De Ruiter, P.C., Dong, Q., Hastings, A., Johnson, N.C., McCann, K.S., Melville, K., Morin, P.J., Nadelhoffer, K.J., Rosemond, A.D., Post, D.M., Sabo, J.L., Scow, K.M., Vanni, M.J., Wall, D.H., 2004. Detritus, trophic dynamics and biodiversity. Ecology Letters 7, 584-600.

Nielsen, L.B., Nielsen, B.O., 2002. Density and phenology of soil gallmidges (Diptera: Cecidomyiidae) in arable land. Pedobiologia 46, 1-14.

Pollierer, M.M., Langel, R., Körner, C., Maraun, M., Scheu, S., 2007. The underestimated importance of belowground carbon input for forest soil animal food webs. Ecology Letters 10, 729-736. 
Postma-Blaauw, M.B., De Goede, R.G.M., Bloem, J., Faber, J., Brussaard, L., 2010. Soil biota community structure and abundance under agricultural intensification and extensification. Ecology 91, 460-473.

Read, D.S., Sheppard, S.K., Bruford, M.W., Glen, D.M., Symondson, W.O.C., 2006. Molecular detection of predation by soil micro-arthropods on nematodes. Molecular Ecology 15, 1963-1972.

Ruess, L., Schütz, K., Migge-Kleian, S., Häggblom, M.M., Kandeler, E., Scheu, S., 2007. Lipid composition of Collembola and their food resources in deciduous forest standsImplications for feeding strategies. Soil Biology \& Biochemistry 39, 1990-2000.

Saitoh, S., Fujii, S., Takeda, H., 2013. Effect of habitat structural complexity on collembolan communities. Ecological Research 29, 81-90.

Salamon, J.-A., Alphei, J., Ruf, A., Schaefer, M., Scheu, S., Schneider, K., Sührig, A., Maraun, M., 2006. Transitory dynamic effects in the soil invertebrate community in a temperate deciduous forest: Effects of resource quality. Soil Biology \& Biochemistry $38,209-221$.

Sayer, E.J., 2006. Using experimental manipulation to assess the roles of leaf litter in the functioning of forest ecosystems. Biological Reviews of the Cambridge Philosophical Society $81,1-31$.

Schaefer, M., 2010. Brohmer - Fauna von Deutschland, 23rd ed. Quelle \& Meyer Verlag, Wiebelsheim.

Scharroba, A., Dibbern, D., Hünninghaus, M., Kramer, S., Moll, J., Butenschoen, O., Bonkowski, M., Buscot, F., Kandeler, E., Koller, R., Krüger, D., Lueders, T., Scheu, S., Ruess, L., 2012. Effects of resource availability and quality on the structure of the micro-food web of an arable soil across depth. Soil Biology \& Biochemistry 50, 1-11.

Scheunemann, N., Scheu, S., Butenschoen, O., 2010. Incorporation of decade old soil carbon into the soil animal food web of an arable system. Applied Soil Ecology 46, 59-63.

Schneider, T., Keiblinger, K.M., Schmid, E., Sterflinger-Gleixner, K., Ellersdorfer, G., Roschitzki, B., Richter, A., Eberl, L., Zechmeister-Boltenstern, S., Riedel, K., 2012. Who is who in litter decomposition? Metaproteomics reveals major microbial players and their biogeochemical functions. The ISME Journal 6, 1749-1762. 
Semenyuk, I.I., Tiunov, A.V., 2011. Isotopic signature $\left({ }^{15} \mathrm{~N} /{ }^{14} \mathrm{~N}\right.$ and $\left.{ }^{13} \mathrm{C} /{ }^{12} \mathrm{C}\right)$ confirms similarity of trophic niches of millipedes (Myriapoda, diplopoda) in a temperate deciduous forest. Biology Bulletin 38, 283-291.

Sharratt, B.S., McWilliams, D.A.., 2005. Microclimatic and rooting characteristics of narrow-row versus conventional-row corn. Agronomy Journal 97, 1129-1135.

Tilman, D., Balzer, C., Hill, J., Befort, B.L., 2011. Global food demand and the sustainable intensification of agriculture. Proceedings of the National Academy of Sciences of the United States of America 108, 20260-20264.

Weigmann, G., 2006. Die Tierwelt Deutschlands Teil 76 - Hornmilben (Oribatida), 1st ed. Goecke \& Evers.

Wilhelm, W.W., Johnson, J.M.F., Hatfield, J.L., Voorhees, W.B., Linden, D.R., 2004. Crop and soil productivity response to corn residue removal: A literature review. Agronomy Journal 96, 1-17. 


\section{Supporting information}


abundance of individual taxa; ${ }^{*} p<0.05,{ }^{* *} p<0.01, * * * p<0.001$. Coll. $=$ Collembola, Dipl. $=$ Diplura, Stern. $=$ Sternorrhyncha, Auch. $=$ Auchenorrhyncha, Thys.=Thysanoptera, Dipt.=Diptera, Hym. $=$ Hymenoptera, Coleop.=Coleoptera, Cole. juv. $=$ Coleoptera larvae, Gama. $=$ Gamasida (Mesostigmata), Orib.=Oribatida (Cryptostigmata), Symph. $=$ Symphyla, Chilop. $=$ Chilopoda, Diplop.=Diplopoda, Aran. $=$ Araneae.

\begin{tabular}{|c|c|c|c|c|c|c|c|c|c|c|c|c|c|c|}
\hline \multirow[b]{2}{*}{ full taxon name } & \multirow[b]{2}{*}{$\begin{array}{l}\text { Abbre- } \\
\text { viation }\end{array}$} & \multirow[b]{2}{*}{$\begin{array}{l}\text { Taxonomic } \\
\text { group }\end{array}$} & \multirow[b]{2}{*}{$\begin{array}{l}\text { Average } \\
\text { abundance } \\
\text { [Indiv. } \mathbf{m}^{-2} \text { ] }\end{array}$} & \multirow[b]{2}{*}{ SEM } & \multicolumn{3}{|c|}{ all sampling dates } & \multicolumn{7}{|c|}{ December 2009 and July 2010 (after residue addition) } \\
\hline & & & & & $\begin{array}{c}\text { Sampling } \\
\text { date }\end{array}$ & $\begin{array}{c}\text { Crop } \\
\text { species }\end{array}$ & $\begin{array}{c}\text { Sampling } \\
\text { date } \\
\times \\
\text { Crop } \\
\text { species } \\
\\
F_{3,56} \\
\end{array}$ & $\begin{array}{c}\text { Sampling } \\
\text { date }\end{array}$ & $\begin{array}{c}\text { Crop } \\
\text { species }\end{array}$ & $\begin{array}{c}\begin{array}{c}\text { Residue } \\
\text { addition }\end{array} \\
\mathrm{F}_{1,24} \\
\end{array}$ & $\begin{array}{c}\text { Sampling } \\
\text { date } \\
\times \\
\text { Crop } \\
\text { species } \\
\\
F_{1,24} \\
\end{array}$ & $\begin{array}{c}\text { Sampling } \\
\text { date } \\
\times \\
\text { Residue } \\
\text { addition } \\
\\
F_{1,24} \\
\end{array}$ & $\begin{array}{c}\text { Crop } \\
\text { species } \\
\times \\
\text { Residue } \\
\text { addition } \\
\\
\\
\\
F_{1,24} \\
\end{array}$ & $\begin{array}{c}\text { Sampling } \\
\text { date } \\
\times \\
\text { Crop } \\
\text { species } \\
\times \\
\text { Residue } \\
\text { addition } \\
\\
F_{1,24} \\
\end{array}$ \\
\hline $\begin{array}{l}\text { Allonychiurus edinensis } \\
\text { (Bagnall, 1935) }\end{array}$ & Allo_edi & Coll. & 5.7 & 0.7 & 0.89 & 1.58 & 0.15 & 1.32 & 1.32 & 0.44 & 0.44 & 1.32 & 0.03 & 0.44 \\
\hline $\begin{array}{l}\text { Bourletiella hortensis } \\
\text { (Fitch, 1863) }\end{array}$ & Bour_hor & Coll. & 158.8 & 19.9 & $\begin{array}{c}13.97 \\
* * *\end{array}$ & 3.78 & $\begin{array}{c}5.13 \\
* *\end{array}$ & 1.58 & $\begin{array}{c}13.91 \\
* *\end{array}$ & 1.09 & 1.24 & 0.02 & 3.12 & 4.14 \\
\hline $\begin{array}{l}\text { Caprainea marginata } \\
\text { (Schött, 1893) }\end{array}$ & Capr_mar & Coll. & 0.9 & 0.1 & $\begin{array}{c}3.10 \\
*\end{array}$ & 0.66 & 0.66 & 2.80 & 0.59 & 0.02 & 0.59 & 0.02 & 0.59 & 0.59 \\
\hline $\begin{array}{l}\text { Cryptopygus } \\
\text { scapelliferus (Gisin, } \\
\text { 1955) }\end{array}$ & Cryp_sca & Coll. & 14.0 & 1.8 & $\begin{array}{c}3.72 \\
*\end{array}$ & 2.70 & 0.38 & 1.26 & 2.48 & 0.12 & 0.52 & 0.77 & 0.12 & 0.77 \\
\hline $\begin{array}{l}\text { Heteromurus nitidus } \\
\text { (Templeton, 1835) }\end{array}$ & Hete_nit & Coll. & 177.0 & 22.1 & $\begin{array}{c}8.00 \\
* * *\end{array}$ & $\begin{array}{c}74.55 \\
* * *\end{array}$ & $\begin{array}{c}13.14 \\
* * *\end{array}$ & 2.58 & $\begin{array}{c}22.91 \\
* * *\end{array}$ & 2.03 & 0.90 & 0.00 & 0.59 & 0.08 \\
\hline $\begin{array}{l}\text { Isotoma viridis } \\
\text { (Bourlet, 1839) }\end{array}$ & Isot_vir & Coll. & 2529.6 & 316.2 & $\begin{array}{c}18.63 \\
* * *\end{array}$ & $\begin{array}{c}271.85 \\
* * *\end{array}$ & $\begin{array}{c}28.48 \\
* * *\end{array}$ & $\begin{array}{c}23.73 \\
* * *\end{array}$ & $\begin{array}{c}102.47 \\
* * *\end{array}$ & 1.06 & $\begin{array}{c}38.85 \\
* * *\end{array}$ & 0.95 & 0.09 & 3.72 \\
\hline $\begin{array}{l}\text { Lepidocyrtus cyaneus } \\
\text { (Tullberg, 1871) }\end{array}$ & Lepi_cya & Coll. & 972.3 & 121.5 & $\begin{array}{l}30.37 \\
* * *\end{array}$ & $\begin{array}{c}148.28 \\
* * *\end{array}$ & $\begin{array}{c}11.40 \\
* * *\end{array}$ & $\begin{array}{c}26.24 \\
* * *\end{array}$ & $\begin{array}{c}147.03 \\
* * *\end{array}$ & 0.01 & 3.32 & 2.28 & 0.68 & 0.00 \\
\hline $\begin{array}{l}\text { Neotullbergia tricuspis } \\
\text { (Börner, 1902) }\end{array}$ & Neot_tri & Coll. & 1.3 & 0.2 & 2.19 & 1.42 & 0.62 & 1.00 & 1.00 & 1.00 & 1.00 & 1.00 & 1.00 & 1.00 \\
\hline $\begin{array}{l}\text { Parisotoma notabilis } \\
\text { (Schäffer, 1896) }\end{array}$ & Pari_not & Coll. & 413.7 & 51.7 & $\begin{array}{c}3.28 \\
*\end{array}$ & $\begin{array}{c}25.99 \\
* * *\end{array}$ & $\begin{array}{c}4.37 \\
* *\end{array}$ & 2.45 & $\begin{array}{c}48.54 \\
* * *\end{array}$ & 1.51 & 0.63 & $\begin{array}{c}14.73 \\
* * *\end{array}$ & 2.31 & 0.45 \\
\hline $\begin{array}{l}\text { Protaphorura armata } \\
\text { (Tullberg, 1869) }\end{array}$ & Prot_arm & Coll. & 271.7 & 34.0 & 0.90 & 0.42 & $\begin{array}{c}3.71 \\
*\end{array}$ & 0.25 & 2.13 & 1.97 & 0.91 & 0.06 & 0.23 & 0.29 \\
\hline
\end{tabular}


Abundances of soil arthropods in arable fields

\begin{tabular}{|c|c|c|c|c|c|c|c|c|c|c|c|c|c|c|}
\hline $\begin{array}{l}\text { Pseudosinella alba } \\
\text { (Packard, 1873) }\end{array}$ & Pseu_sin & Coll. & 409.5 & 51.2 & $\begin{array}{c}4.79 \\
* *\end{array}$ & $\begin{array}{l}32.66 \\
* * *\end{array}$ & $\begin{array}{l}4.25 \\
* *\end{array}$ & $\begin{array}{c}6.70 \\
*\end{array}$ & $\begin{array}{c}26.88 \\
* * *\end{array}$ & 0.26 & 0.04 & 1.94 & 0.13 & 0.09 \\
\hline $\begin{array}{l}\text { Sphaeridia pumilis } \\
\text { (Krausbauer, 1898) }\end{array}$ & Spha_pum & Coll. & 3.7 & 0.5 & $\begin{array}{l}15.86 \\
* * *\end{array}$ & $\underset{* *}{11.34}$ & $\underset{* * *}{11.34}$ & $\begin{array}{c}14.35 \\
* * *\end{array}$ & $\begin{array}{c}10.27 \\
* *\end{array}$ & 0.63 & $\begin{array}{c}10.27 \\
* *\end{array}$ & 0.63 & 0.04 & 0.04 \\
\hline $\begin{array}{l}\text { Stenaphorura denisi } \\
\text { (Bagnall, 1935) }\end{array}$ & Sten_den & Coll. & 10.9 & 1.4 & $\begin{array}{c}3.08 \\
*\end{array}$ & 0.22 & 0.84 & 0.54 & 0.23 & 1.07 & 1.12 & 0.20 & 0.50 & 0.97 \\
\hline $\begin{array}{l}\text { Willowsia buski } \\
\text { (Lubbock, 1869) }\end{array}$ & Will_bus & Coll. & 33.7 & 4.2 & $\begin{array}{l}8.31 \\
* * *\end{array}$ & $\begin{array}{c}5.42 \\
*\end{array}$ & 0.29 & $\begin{array}{c}16.67 \\
* * *\end{array}$ & 2.77 & 0.75 & 0.53 & 0.54 & 0.78 & 1.50 \\
\hline $\begin{array}{l}\text { Xenylla boerneri } \\
\text { (Axelson, 1905) }\end{array}$ & Xeny_boe & Coll. & 2.0 & 0.2 & 2.23 & 0.03 & 2.36 & 0.19 & 0.03 & 0.03 & 3.27 & 0.36 & 1.45 & 0.19 \\
\hline $\begin{array}{l}\text { Campodea staphylinus } \\
\text { (Westwood, 1842) }\end{array}$ & Camp_sta & Dipl. & 2.8 & 0.4 & 1.13 & 0.01 & 0.13 & 0.25 & 0.01 & 1.18 & 0.25 & 0.25 & 0.01 & 2.79 \\
\hline $\begin{array}{l}\text { Aphidinae } \\
\text { (Latreille, 1802) }\end{array}$ & Aphidin & Stern. & 189.7 & 23.7 & $\begin{array}{c}13.42 \\
* * *\end{array}$ & $\begin{array}{c}17.88 \\
* * *\end{array}$ & $\begin{array}{c}5.09 \\
* *\end{array}$ & $\begin{array}{c}32.27 \\
* * *\end{array}$ & $\begin{array}{c}19.24 \\
* * *\end{array}$ & 1.51 & $\begin{array}{c}11.24 \\
* *\end{array}$ & 0.60 & 0.83 & 0.21 \\
\hline Cicada larvae & Cica_Lar & Auch. & 2.8 & 0.4 & 0.70 & 1.97 & $\begin{array}{c}3.41 \\
*\end{array}$ & 0.58 & $\begin{array}{c}7.98 \\
* *\end{array}$ & 1.69 & 0.58 & 0.58 & 1.69 & 0.58 \\
\hline $\begin{array}{l}\text { Halpothrips aculeatus } \\
\text { (Fabricius, 1803) }\end{array}$ & Hapl_acu & Thys. & 48.6 & 6.1 & $\begin{array}{c}14.44 \\
* * * \\
\end{array}$ & $\begin{array}{c}14.81 \\
* * * \\
\end{array}$ & $\begin{array}{c}4.43 \\
* *\end{array}$ & $\begin{array}{c}14.94 \\
* * *\end{array}$ & $\begin{array}{c}15.23 \\
* * *\end{array}$ & 1.06 & 3.10 & 3.59 & 0.04 & 2.37 \\
\hline $\begin{array}{l}\text { Cecidmyiidae adult } \\
\text { (Newman, 1834) }\end{array}$ & Ceci_Adu & Dipt. & 15.5 & 1.9 & $\begin{array}{c}5.03 \\
* *\end{array}$ & 0.35 & 0.16 & $\begin{array}{c}9.37 \\
* *\end{array}$ & 0.82 & $\begin{array}{c}6.62 \\
*\end{array}$ & 0.01 & 2.55 & $\begin{array}{c}5.61 \\
*\end{array}$ & 1.94 \\
\hline $\begin{array}{l}\text { Cecidmyiidae larvae } \\
\text { (Newman, 1834) }\end{array}$ & Ceci_Lar & Dipt. & 129.5 & 16.2 & $\begin{array}{c}3.13 \\
*\end{array}$ & 0.02 & 1.31 & $\begin{array}{c}25.95 \\
* * *\end{array}$ & 0.28 & 2.06 & 1.01 & $\begin{array}{c}5.44 \\
*\end{array}$ & 0.00 & 0.02 \\
\hline $\begin{array}{l}\text { Muscidae larvae } \\
\text { (Latreille, 1802) }\end{array}$ & Musc_Lar & Dipt. & 38.7 & 4.8 & $\begin{array}{c}4.51 \\
* *\end{array}$ & $\begin{array}{l}7.46 \\
* *\end{array}$ & 1.21 & 3.67 & $\begin{array}{c}5.23 \\
*\end{array}$ & 0.43 & 1.15 & 1.21 & 0.28 & 1.38 \\
\hline $\begin{array}{l}\text { Tipulidae larvae } \\
\text { (Latreille, 1802) }\end{array}$ & Tipu_Lar & Dipt. & 3.3 & 0.4 & 1.03 & 2.60 & 1.03 & 0.42 & 1.22 & 0.00 & 0.00 & 1.22 & 0.42 & 3.07 \\
\hline $\begin{array}{l}\text { Mymaridae } \\
\text { (Haliday, 1833) }\end{array}$ & Mymari & Hym. & 12.0 & 1.5 & $\begin{array}{c}6.08 \\
*\end{array}$ & $\begin{array}{c}7.65 \\
*\end{array}$ & $\begin{array}{c}4.23 \\
*\end{array}$ & $\begin{array}{c}8.10 \\
* *\end{array}$ & $\begin{array}{c}8.10 \\
* *\end{array}$ & 0.09 & $\begin{array}{c}6.13 \\
*\end{array}$ & 1.41 & 0.01 & 0.09 \\
\hline $\begin{array}{l}\text { Aleocharinae } \\
\text { (Fleming, 1821) }\end{array}$ & Aleocha & Coleop. & 1.1 & 0.1 & 3.24 & 0.23 & 0.23 & - & - & - & - & - & - & - \\
\hline $\begin{array}{l}\text { Bembidion sp. } \\
\text { (Latreille, 1802) }\end{array}$ & Bemb_sp & Coleop. & 17.1 & 2.1 & 0.35 & $\begin{array}{c}40.61 \\
* * *\end{array}$ & 1.55 & 1.00 & $\begin{array}{c}51.29 \\
* * *\end{array}$ & 3.92 & 0.25 & 0.08 & $\begin{array}{c}6.14 \\
*\end{array}$ & 0.60 \\
\hline $\begin{array}{l}\text { Ephistemus globulus } \\
\text { (Paykull, 1798) }\end{array}$ & Ephi_glo & Coleop. & 7.0 & 0.9 & 0.60 & 7.87 & 0.60 & 0.01 & $\begin{array}{c}5.45 \\
*\end{array}$ & 0.01 & 0.01 & 2.68 & 0.01 & 2.68 \\
\hline $\begin{array}{l}\text { Lathrobium sp. } \\
\text { (Gravenhorst, 1802) }\end{array}$ & Lath_sp & Coleop. & 1.5 & 0.2 & 1.35 & 0.99 & 0.37 & 3.64 & 0.77 & 3.64 & 0.77 & 3.64 & 0.77 & 0.77 \\
\hline $\begin{array}{l}\text { Leptacinus sp. } \\
\text { (Erichson, 1839) }\end{array}$ & Lept_sp & Coleop. & 4.4 & 0.5 & $\begin{array}{c}6.07 \\
* *\end{array}$ & $\begin{array}{c}6.07 \\
*\end{array}$ & $\begin{array}{c}6.07 \\
* *\end{array}$ & $\begin{array}{c}5.37 \\
*\end{array}$ & $\begin{array}{c}5.37 \\
*\end{array}$ & 0.19 & $\begin{array}{c}5.37 \\
*\end{array}$ & 0.19 & 0.19 & 0.19 \\
\hline $\begin{array}{l}\text { Notiophilus biguttatus } \\
\text { (Fabricius, 1779) }\end{array}$ & Noti_big & Coleop. & 1.5 & 0.2 & $\begin{array}{l}9.76 \\
* * *\end{array}$ & $\begin{array}{c}9.76 \\
* *\end{array}$ & $\begin{array}{l}9.76 \\
* * *\end{array}$ & $\begin{array}{c}8.41 \\
* *\end{array}$ & $\begin{array}{c}8.41 \\
* *\end{array}$ & 0.04 & $\begin{array}{c}8.41 \\
* *\end{array}$ & 0.04 & 0.04 & 0.04 \\
\hline $\begin{array}{l}\text { Paederinae } \\
\text { (Fleming, 1821) }\end{array}$ & Paeder & Coleop. & 19.5 & 2.4 & $\begin{array}{c}3.99 \\
*\end{array}$ & $\underset{* * *}{12.74}$ & 2.36 & $\begin{array}{c}8.40 \\
* *\end{array}$ & $\begin{array}{c}8.56 \\
* *\end{array}$ & 0.05 & 3.18 & 0.01 & 0.55 & 0.00 \\
\hline
\end{tabular}


Abundances of soil arthropods in arable fields

\begin{tabular}{|c|c|c|c|c|c|c|c|c|c|c|c|c|c|c|}
\hline $\begin{array}{l}\text { Ptiliidae } \\
\text { (Heer, 1843) }\end{array}$ & Ptiliid & Coleop. & 18.4 & 2.3 & 2.62 & 3.10 & 1.43 & 3.42 & 3.42 & 0.18 & 3.42 & 0.18 & 0.18 & 0.18 \\
\hline $\begin{array}{l}\text { Quedius nitipennis } \\
\text { (Stephens, 1833) }\end{array}$ & Qued_nit & Coleop. & 1.1 & 0.1 & 1.37 & 1.30 & 0.63 & 3.00 & 3.00 & 3.00 & 3.00 & 3.00 & 3.00 & 3.00 \\
\hline $\begin{array}{l}\text { Scopaeus sp. } \\
\text { (Erichson, 1839) }\end{array}$ & Scop_sp & Coleop. & 1.1 & 0.1 & $\begin{array}{c}4.36 \\
* *\end{array}$ & $\begin{array}{c}7.61 \\
* *\end{array}$ & $\begin{array}{c}4.36 \\
* *\end{array}$ & $\begin{array}{c}8.00 \\
* *\end{array}$ & $\begin{array}{l}8.00 \\
* *\end{array}$ & 2.00 & $\begin{array}{c}8.00 \\
* *\end{array}$ & 2.00 & 2.00 & 2.00 \\
\hline $\begin{array}{l}\text { Trechus sp. } \\
\text { (Clairvill, 1806) }\end{array}$ & Trec_sp & Coleop. & 12.7 & 1.6 & $\begin{array}{c}38.13 \\
* * *\end{array}$ & $\begin{array}{c}41.27 \\
* * *\end{array}$ & $\begin{array}{c}16.95 \\
* * *\end{array}$ & $\begin{array}{c}8.01 \\
* *\end{array}$ & $\begin{array}{c}4.66 \\
*\end{array}$ & 1.02 & $\begin{array}{c}4.66 \\
*\end{array}$ & 1.02 & 0.11 & 0.11 \\
\hline $\begin{array}{l}\text { Xantholinus sp. } \\
\text { (Dejean, 1821) }\end{array}$ & Xant_sp & Coleop. & 2.6 & 0.3 & 1.40 & $\begin{array}{c}7.09 \\
*\end{array}$ & 0.86 & 0.14 & $\begin{array}{c}5.85 \\
*\end{array}$ & 0.83 & 0.14 & 1.28 & 0.83 & 1.28 \\
\hline $\begin{array}{l}\text { Anthribidae larvae } \\
\text { (Billberg, 1820) }\end{array}$ & Anth_Lar & Cole. juv. & 2.4 & 0.3 & 5.23 & 5.37 & 2.86 & $\begin{array}{c}8.98 \\
* *\end{array}$ & $\begin{array}{c}4.98 \\
*\end{array}$ & 0.85 & $\begin{array}{c}4.98 \\
*\end{array}$ & 0.85 & 2.85 & 2.85 \\
\hline $\begin{array}{l}\text { Cantaridae larvae } \\
\text { (Imhoff, 1856) }\end{array}$ & Cant_Lar & Cole. juv. & 5.9 & 0.7 & 1.89 & $\begin{array}{l}4.02 \\
*\end{array}$ & 1.89 & 2.65 & 2.65 & 1.61 & 2.65 & 1.61 & 1.61 & 1.61 \\
\hline $\begin{array}{l}\text { Carabidae larvae } \\
\text { (Latreille, 1802) }\end{array}$ & Cara_Lar & Cole. juv. & 30.0 & 3.7 & $\begin{array}{c}3.06 \\
*\end{array}$ & $\underset{* * *}{28.22}$ & $\begin{array}{c}5.12 \\
* *\end{array}$ & 1.37 & $\begin{array}{c}20.77 \\
* * *\end{array}$ & 0.00 & 0.53 & 0.32 & 0.41 & 0.00 \\
\hline $\begin{array}{l}\text { Elateridae larvae } \\
\text { (Leach, 1815) }\end{array}$ & Elat_Lar & Cole. juv. & 23.0 & 2.9 & 2.56 & $\begin{array}{c}7.59 \\
* *\end{array}$ & 0.81 & 4.17 & $\begin{array}{c}6.92 \\
*\end{array}$ & 0.14 & 0.21 & 0.27 & 0.56 & 0.06 \\
\hline $\begin{array}{l}\text { Staphylinidae larvae } \\
\text { (Latreille, 1802) }\end{array}$ & Stap_Lar & Cole. juv. & 70.4 & 8.8 & $\begin{array}{c}17.68 \\
* * *\end{array}$ & 2.60 & 1.19 & $\begin{array}{c}20.00 \\
* * *\end{array}$ & $\begin{array}{c}4.26 \\
*\end{array}$ & 1.18 & 1.68 & 7.35 & 1.77 & 3.83 \\
\hline $\begin{array}{l}\text { Alliphis siculus } \\
\text { (Oudemans, 1905) }\end{array}$ & Alli_sic & Gama. & 159.3 & 19.9 & $\begin{array}{l}6.47 \\
* * *\end{array}$ & 3.19 & $\begin{array}{c}3.61 \\
*\end{array}$ & 1.04 & $\begin{array}{c}15.80 \\
* * *\end{array}$ & $\begin{array}{c}23.95 \\
* * *\end{array}$ & 0.16 & 2.58 & 0.23 & 0.64 \\
\hline $\begin{array}{l}\text { Geholaspis mandibularis } \\
\text { (Berlese, 1904) }\end{array}$ & Geho_man & Gama. & 34.3 & 4.3 & $\begin{array}{c}3.66 \\
*\end{array}$ & 2.67 & 0.87 & $\begin{array}{c}14.53 \\
* * *\end{array}$ & 0.47 & 0.83 & 0.23 & 1.24 & 0.02 & 0.41 \\
\hline $\begin{array}{l}\text { Hypoaspis aculeifer } \\
\text { (Canestrini, 1884) }\end{array}$ & Hypo_acu & Gama. & 91.2 & 11.4 & 2.74 & $\begin{array}{c}63.93 \\
* * *\end{array}$ & $\begin{array}{c}3.80 \\
*\end{array}$ & $\begin{array}{c}7.57 \\
*\end{array}$ & $\begin{array}{c}84.37 \\
* * *\end{array}$ & 0.14 & $\begin{array}{c}6.20 \\
*\end{array}$ & 0.03 & 0.01 & 3.06 \\
\hline $\begin{array}{l}\text { Lysigamasus sp. } \\
\text { (Karg, 1971) }\end{array}$ & Lysi_sp & Gama. & 84.2 & 10.5 & $\underset{* *}{5.52}$ & $\begin{array}{c}20.06 \\
* * *\end{array}$ & 1.52 & $\begin{array}{c}5.38 \\
*\end{array}$ & $\begin{array}{c}13.25 \\
* *\end{array}$ & 1.40 & $\begin{array}{c}4.85 \\
*\end{array}$ & 1.53 & 0.52 & 0.76 \\
\hline $\begin{array}{l}\text { Nenteria } \\
\text { breviunguiculata } \\
\text { (Willmann, 1949) }\end{array}$ & Nent_bre & Gama. & 21.0 & 2.6 & $\begin{array}{l}6.71 \\
* * *\end{array}$ & $\begin{array}{c}11.94 \\
* *\end{array}$ & $\begin{array}{c}3.12 \\
*\end{array}$ & $\begin{array}{c}10.17 \\
* *\end{array}$ & $\begin{array}{c}13.14 \\
* *\end{array}$ & 3.68 & 2.15 & 1.64 & 0.04 & 0.19 \\
\hline $\begin{array}{l}\text { Pergamasinae } \\
\text { (Juvara-Bals, 1976) }\end{array}$ & Pergama & Gama. & 168.0 & 21.0 & $\begin{array}{c}33.24 \\
* * *\end{array}$ & $\begin{array}{c}56.03 \\
* * *\end{array}$ & $\begin{array}{c}12.60 \\
* * *\end{array}$ & $\begin{array}{c}58.89 \\
* * *\end{array}$ & $\begin{array}{c}106.29 \\
* * *\end{array}$ & 0.02 & $\begin{array}{c}28.36 \\
* * *\end{array}$ & $\begin{array}{c}10.30 \\
* *\end{array}$ & 0.31 & 0.28 \\
\hline $\begin{array}{l}\text { Pergamasus crassipes } \\
\text { (Linnaeus, 1758) }\end{array}$ & Perg_cra & Gama. & 140.0 & 17.5 & $\begin{array}{c}4.77 \\
* *\end{array}$ & $\begin{array}{c}59.13 \\
* * *\end{array}$ & 2.52 & $\begin{array}{c}13.06 \\
* *\end{array}$ & $\begin{array}{c}36.70 \\
* * *\end{array}$ & 2.17 & $\begin{array}{c}7.51 \\
*\end{array}$ & 0.05 & 0.19 & 0.20 \\
\hline $\begin{array}{l}\text { Rhodacaridae } \\
\text { (Oudemans, 1902) }\end{array}$ & Rhodaca & Gama. & 28.4 & 3.6 & $\begin{array}{l}9.22 \\
* * *\end{array}$ & $\begin{array}{c}9.35 \\
* *\end{array}$ & $\begin{array}{c}5.09 \\
* *\end{array}$ & 1.10 & $\begin{array}{l}7.57 \\
*\end{array}$ & 0.93 & $\begin{array}{c}6.33 \\
*\end{array}$ & 0.04 & 2.99 & 0.13 \\
\hline $\begin{array}{l}\text { Tetranychidae } \\
\text { (Donnadieu, 1875) }\end{array}$ & Tetrany & Gama. & 25.6 & 3.2 & $\begin{array}{c}38.36 \\
* * * \\
\end{array}$ & $\begin{array}{c}6.77 \\
*\end{array}$ & $\begin{array}{c}5.09 \\
* *\end{array}$ & $\begin{array}{c}35.02 \\
* * * \\
\end{array}$ & $\begin{array}{c}5.65 \\
*\end{array}$ & 0.02 & $\begin{array}{c}4.52 \\
*\end{array}$ & 0.14 & 0.87 & 0.46 \\
\hline $\begin{array}{l}\text { Brachychthonius sp. } \\
\text { (Berlese, 1910) }\end{array}$ & Brachych & Orib. & 3.9 & 0.5 & $\begin{array}{l}8.03 \\
* * *\end{array}$ & 0.27 & 0.72 & $\begin{array}{c}7.92 \\
* *\end{array}$ & 0.30 & 2.36 & 1.04 & 4.03 & 0.07 & 0.53 \\
\hline Chamobates sp. & Cham_sp & Orib. & 3.7 & 0.5 & 1.55 & 1.54 & 1.26 & 0.01 & 0.01 & 1.93 & 1.93 & 0.01 & 1.93 & 1.93 \\
\hline
\end{tabular}


Abundances of soil arthropods in arable fields

\begin{tabular}{|c|c|c|c|c|c|c|c|c|c|c|c|c|c|c|}
\hline \multicolumn{15}{|l|}{ (Hull, 1916) } \\
\hline $\begin{array}{l}\text { Damaeidae } \\
\text { (Berlese, 1896) }\end{array}$ & Damaeid & Orib. & 1.1 & 0.1 & 2.66 & 0.01 & 0.01 & 2.55 & 0.01 & 0.72 & 0.01 & 0.72 & 0.72 & 0.72 \\
\hline $\begin{array}{l}\text { Oppiella nova } \\
\text { (Oudemans, 1902) }\end{array}$ & Oppi_nov & Orib. & 24.5 & 3.1 & $\begin{array}{c}5.23 \\
* *\end{array}$ & $\begin{array}{c}20.34 \\
* * *\end{array}$ & $\begin{array}{l}6.62 \\
* * *\end{array}$ & 4.20 & $\begin{array}{c}24.45 \\
* * *\end{array}$ & 1.53 & $\begin{array}{c}6.84 \\
*\end{array}$ & $\begin{array}{c}5.23 \\
*\end{array}$ & 1.53 & $\begin{array}{c}5.23 \\
*\end{array}$ \\
\hline $\begin{array}{l}\text { Phthiracaridae } \\
\text { (Perty, 1841) }\end{array}$ & Phthira & Orib. & 1.3 & 0.2 & 1.93 & 0.01 & 0.01 & 2.80 & 0.02 & 0.59 & 0.02 & 0.59 & 0.59 & 0.59 \\
\hline $\begin{array}{l}\text { Platynothrus sp. } \\
\text { (Berlese, 1913) }\end{array}$ & Plat_sp & Orib. & 1.5 & 0.2 & 1.83 & 0.13 & 1.70 & 0.11 & 0.11 & 0.11 & 2.21 & 0.02 & 0.66 & 0.11 \\
\hline $\begin{array}{l}\text { Tectocepheus velatus } \\
\text { (Michael, 1880) }\end{array}$ & Tect_vel & Orib. & 179.6 & 22.4 & $\begin{array}{c}3.11 \\
*\end{array}$ & $\begin{array}{c}6.85 \\
*\end{array}$ & 0.21 & 2.97 & 3.78 & 0.89 & 0.57 & 2.52 & 0.42 & 0.63 \\
\hline $\begin{array}{l}\text { Symphylella vulgaris } \\
\text { (Hansen, 1903) }\end{array}$ & Symp_vul & Symph. & 147.9 & 18.5 & $\begin{array}{l}9.05 \\
* * * \\
\end{array}$ & 0.01 & 2.16 & $\begin{array}{c}21.68 \\
* * * \\
\end{array}$ & 2.60 & 0.22 & 0.35 & 0.02 & 3.88 & 0.16 \\
\hline $\begin{array}{l}\text { Lamyctes fulvicornis } \\
\text { (Meinert, 1868) }\end{array}$ & Lamy ful & Chilop. & 38.5 & 4.8 & $\begin{array}{c}32.14 \\
* * *\end{array}$ & 2.65 & $\begin{array}{c}3.21 \\
*\end{array}$ & $\begin{array}{c}81.07 \\
* * *\end{array}$ & $\begin{array}{c}5.01 \\
*\end{array}$ & 1.08 & $\begin{array}{c}5.01 \\
*\end{array}$ & 1.08 & 0.04 & 0.04 \\
\hline $\begin{array}{l}\text { Necrophloeophagus } \\
\text { longicornis (Leach, 1814) }\end{array}$ & Necr_lon & Chilop. & 6.3 & 0.8 & $\begin{array}{c}2.85 \\
*\end{array}$ & $\begin{array}{c}4.94 \\
* \\
\end{array}$ & 0.18 & $\begin{array}{c}7.35 \\
*\end{array}$ & 1.84 & 0.00 & 0.04 & 1.34 & 1.34 & 0.00 \\
\hline $\begin{array}{l}\text { Blaniulus guttulatus } \\
\text { (Fabricius, 1798) }\end{array}$ & Blan_gut & Diplop. & 39.4 & 4.9 & $\begin{array}{l}6.30 \\
* * *\end{array}$ & 0.71 & 1.30 & $\begin{array}{c}5.55 \\
*\end{array}$ & 2.95 & 0.05 & 1.05 & 2.42 & 0.29 & 0.79 \\
\hline $\begin{array}{l}\text { Chordeuma sylvestre } \\
\text { (Koch, 1847) }\end{array}$ & Chor_syl & Diplop. & 0.7 & 0.1 & 1.35 & 0.37 & 2.33 & 2.00 & 2.00 & 0.00 & 2.00 & 0.00 & 0.00 & 0.00 \\
\hline $\begin{array}{l}\text { Ophiodesmus albonanus } \\
\text { (Latzel, 1895) }\end{array}$ & Ophi_alb & Diplop. & 26.3 & 3.3 & $\begin{array}{c}2.77 \\
*\end{array}$ & 0.57 & 0.99 & $\begin{array}{c}7.33 \\
*\end{array}$ & 3.67 & 0.15 & 0.01 & $\begin{array}{c}5.74 \\
*\end{array}$ & 0.04 & 1.20 \\
\hline $\begin{array}{l}\text { Polydesmus superus } \\
\text { (Latzel, 1884) }\end{array}$ & Poly_sup & Diplop. & 87.3 & 10.9 & $\begin{array}{l}9.60 \\
* * *\end{array}$ & $\begin{array}{c}6.45 \\
*\end{array}$ & 1.44 & $\begin{array}{l}27.06 \\
* * *\end{array}$ & $\begin{array}{c}6.75 \\
*\end{array}$ & 2.18 & 2.51 & 0.15 & 1.23 & 3.70 \\
\hline $\begin{array}{l}\text { Rhymogona alemannica } \\
\text { (Verhoeff, 1910) }\end{array}$ & Rhym_ale & Diplop. & 1.3 & 0.2 & 4.87 & 1.94 & 1.94 & $\begin{array}{c}4.38 \\
* \\
\end{array}$ & 1.74 & 0.00 & 1.74 & 0.00 & 0.60 & 0.60 \\
\hline $\begin{array}{l}\text { Meioneta sp. } \\
\text { (Hull, 1920) }\end{array}$ & Meio_sp & Aran. & 43.3 & 5.4 & 2.62 & $\begin{array}{c}34.97 \\
* * * \\
\end{array}$ & 1.43 & 0.95 & $\begin{array}{c}30.94 \\
* * * \\
\end{array}$ & 1.67 & 3.41 & 0.05 & 1.13 & 0.00 \\
\hline
\end{tabular}






July

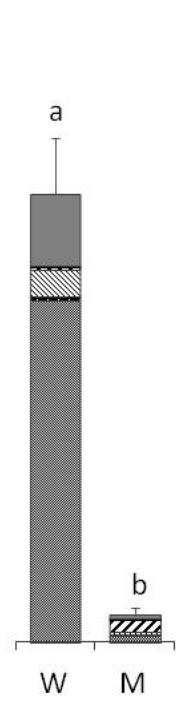

September

2009

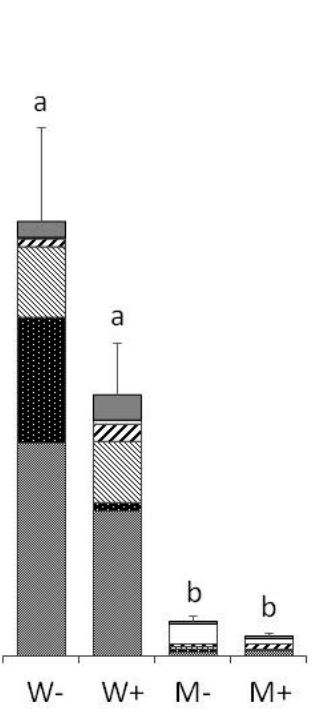

December $\square$ others

$\square$ Bourletiella hortensis Z Protaphorura armata $\mathbb{Q}$ Lepidocyrtus cyaneus - Parisotoma notabilis Isotoma viridis



July

Figure S2: Abundances of Collembola in wheat (W) and maize fields (M) as affected by residue addition (-, without; + , with) and season. Means \pm SEM. Different letters indicate significant differences between treatments at individual sampling dates (Tukey's HSD: $\mathrm{p}<0.05)$.

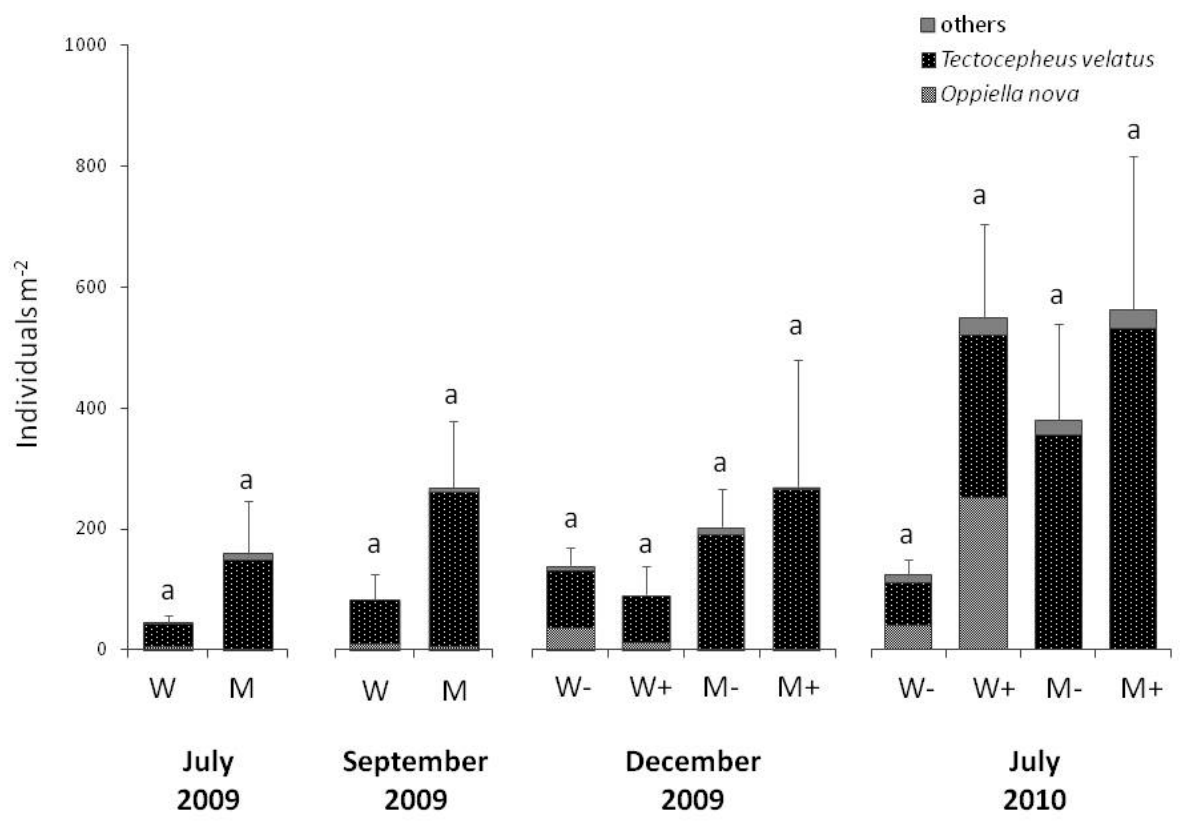

Figure S3: Abundances of Oribatida in wheat (W) and maize fields (M) as affected by residue addition (-, without; + , with) and season. Means \pm SEM. Different letters indicate significant differences between treatments at individual sampling dates (Tukey's HSD: $p<0.05$ ). 


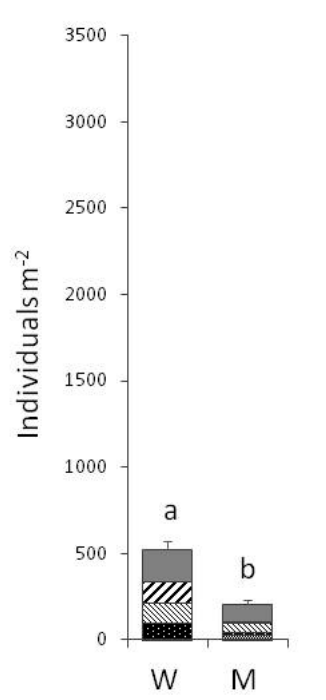

$\begin{array}{cc}\text { July } & \text { September } \\ 2009 & 2009\end{array}$

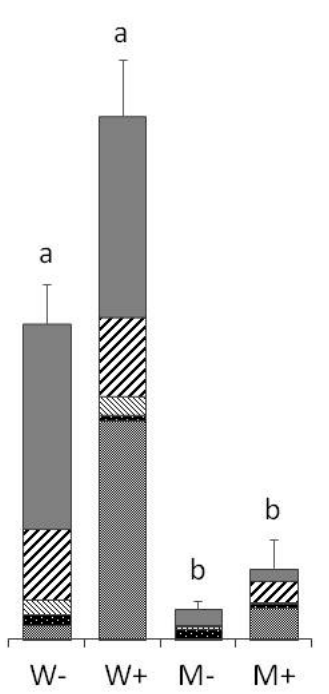

December $\square$ others

Z Pergamasus crassipes

$\mathbb{Q}$ Hypoaspis aculeifer

日 Geholaspis mandibularis

- Alliphis siculus

Figure S4: Abundances of Gamasida in wheat $(\mathrm{W})$ and maize fields $(\mathrm{M})$ as affected by residue addition (-, without; + , with) and season. Means \pm SEM. Different letters indicate significant differences between treatments at individual sampling dates (Tukey's HSD: $p<0.05$ ).
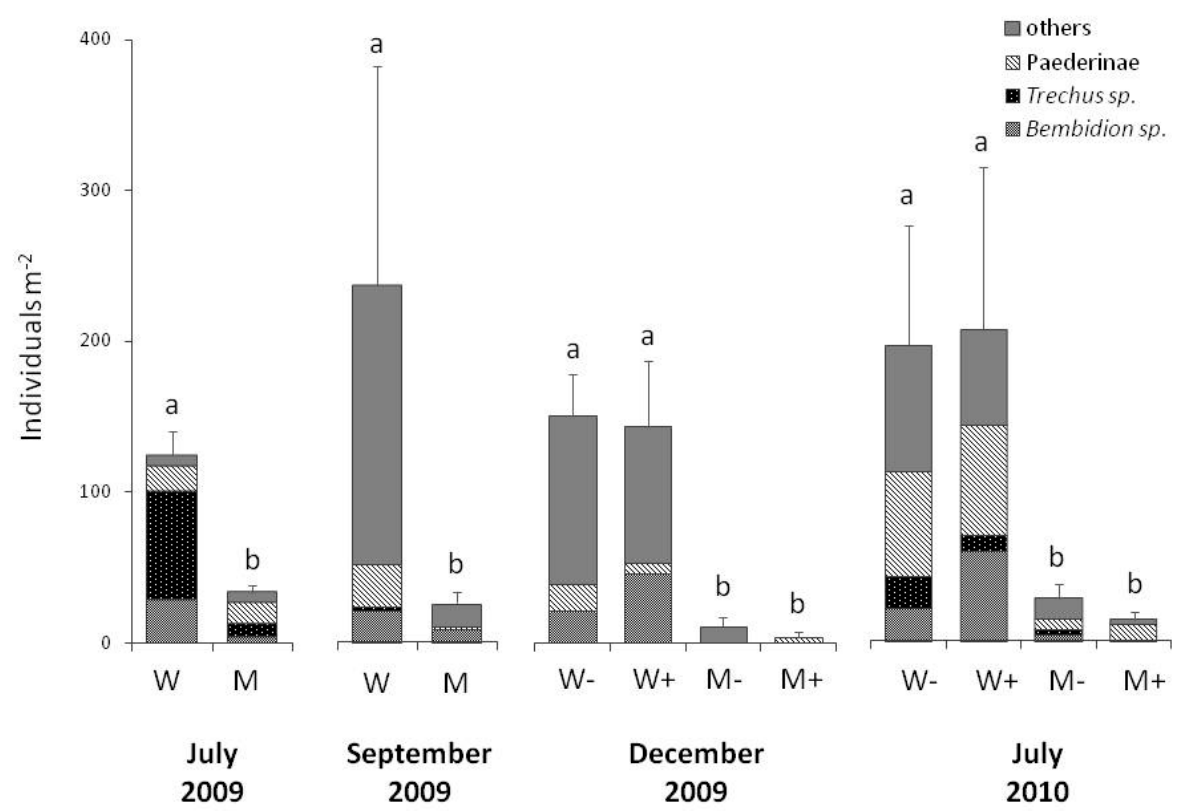

Figure S5: Abundances of adult Coleoptera in wheat (W) and maize fields (M) as affected by residue addition (-, without; + , with) and season. Means \pm SEM. Different letters indicate significant differences between treatments at individual sampling dates (Tukey's HSD: $\mathrm{p}<0.05)$. 




Figure S6: Abundances of Coleoptera larvae in wheat (W) and maize fields (M) as affected by residue addition (-, without; + , with) and season. Means \pm SEM. Different letters indicate significant differences between treatments at individual sampling dates (Tukey's HSD: $\mathrm{p}<0.05)$.

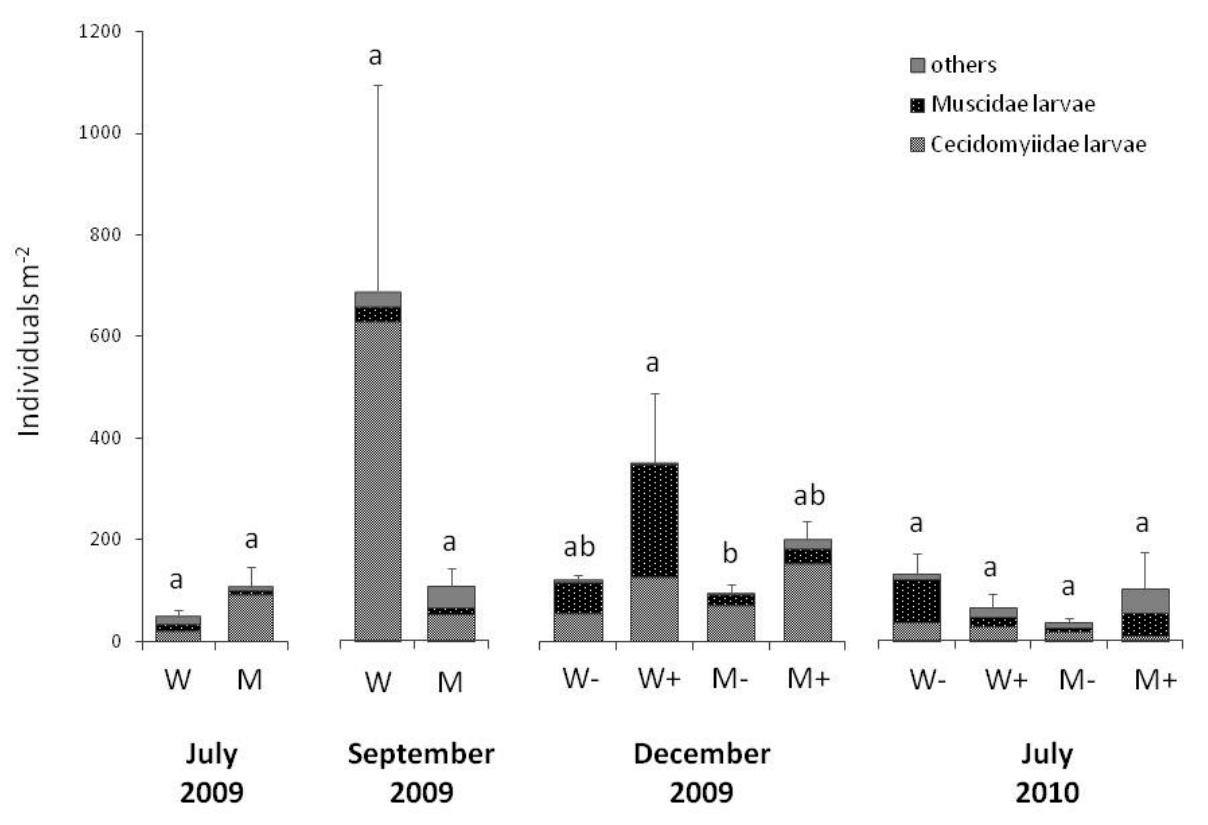

Figure S7: Abundances of Diptera in wheat (W) and maize fields (M) as affected by residue addition (-, without; +, with) and season. Means \pm SEM. Different letters indicate significant differences between treatments at individual sampling dates (Tukey's HSD: $p<0.05$ ). 




Figure S8: Abundances of Chilopoda and Symphyla in wheat (W) and maize fields (M) as affected by residue addition (-, without; + , with) and season. Means \pm SEM. Different letters indicate significant differences between treatments at individual sampling dates (Tukey's HSD: $p<0.05)$.

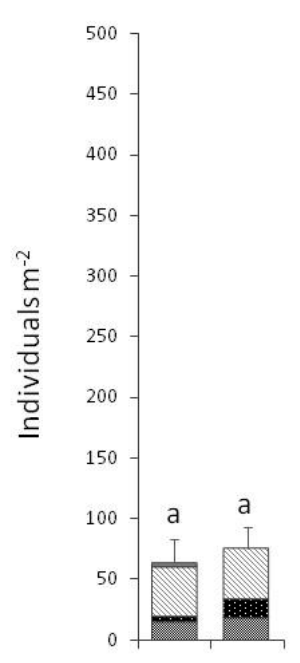

W M

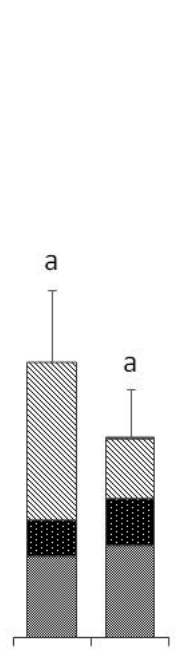

W M

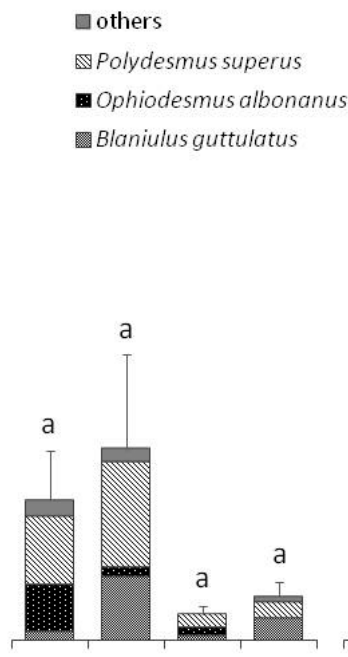

W- $W+M-M+$

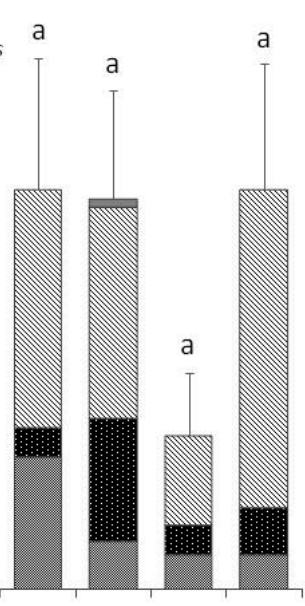

W- $W+M-M+$

$$
\begin{array}{cc}
\text { July } & \text { September } \\
2009 & 2009
\end{array}
$$
December 2009

July

2010

Figure 59: Abundances of Diplopoda in wheat (W) and maize fields (M) as affected by residue addition (-, without; + , with) and season. Means \pm SEM. Different letters indicate significant differences between treatments at individual sampling dates (Tukey's HSD: $\mathrm{p}<0.05)$. 


\section{Chapter 3}

\section{Roots Rather than Shoot Residues Drive SOIL ARTHROPOd COMMUNities Of ARABLE FieldS}

Nicole Scheunemann, Christoph Digel, Stefan Scheu and Olaf Butenschoen



published in Oecologia 179, 1135-1145. 


\begin{abstract}
Soil food webs are driven by plant-derived carbon (C) entering the soil belowground as rhizodeposits or aboveground via leaf litter, with recent research pointing to a higher importance of the former for driving forest soil food webs. Using natural abundance stable isotopes of wheat (C3 plant) and maize (C4 plant) we followed and quantified the incorporation of shoot residue- and root-derived maize $C$ into the soil animal food web of an arable field for one year, thereby disentangling the importance of shoot residue- vs. root-derived resources for arable soil food webs. On average, shoot residue-derived resources contributed only less than $12 \%$ to soil arthropod body $\mathrm{C}$, while incorporation of root-derived resources averaged $26 \%$ after two months of maize crop and increased to $32 \%$ after one year. However, incorporation of root-derived maize C did not consistently increase with time, rather, it increased, decreased or remained constant depending on species. Further, preference of shoot residue- or root-derived resources was also speciesspecific with about half of the species incorporating mainly root-derived $C$, while only few species preferentially incorporated shoot residue-derived C, and about $40 \%$ incorporated both shoot residue- as well as root-derived $C$. The results highlight the predominant importance of root-derived resources for arable soil food webs and suggest that shoot residues only form an additional resource of minor importance. Variation in the use of plant-derived $C$ between soil arthropod species suggests that the flux of $C$ through soil food webs of arable systems can only be disentangled by adopting a species-specific approach.
\end{abstract}

Key words: aboveground; belowground; ${ }^{13} \mathrm{C}$; maize residues; food web 


\section{Introduction}

Soil contains more carbon (C) than both the atmosphere and vegetation combined (Lal, 2004a), and the flux of $C$ between the soil and atmosphere plays a crucial role in regulating atmospheric $\mathrm{CO}_{2}$ concentrations and the Earth's climate (Raich and Schlesinger, 1992; Lal, 2004b). Microorganisms and soil fauna are key drivers determining the decomposition of organic material entering the soil. Therefore, understanding the contribution of soil biota to $\mathrm{C}$ cycling is needed to predict how ecosystems will respond to changes in land use, nutrient input and climate.

Soil biota essentially rely on plant-derived resources entering the soil system either belowground via roots and root exudates or aboveground via shoot residues (Bradford et al., 2012; Pollierer et al., 2012), but the importance of each for fuelling soil food webs remains elusive. The vast majority of terrestrial primary production escapes herbivory and enters the soil as aboveground residues (Cebrian and Lartigue, 2004) that have long been assumed to be the primary $C$ resource for soil biota (Moore et al., 2004; Schneider et al., 2012). However, evidence is mounting that belowground plant inputs form the dominant C resource and determine soil food web structure (Kuzyakov and Domanski, 2000; Eissfeller et al., 2013). For example, in temperate forests and grasslands soil arthropods have been found to predominantly rely on root- rather than leaf litter-derived $C$ (Andresen et al., 2011; Pollierer et al., 2012). Surprisingly, although approximately $40 \%$ of the global ice-free land surface is currently used for agricultural production, little is known on the importance of below- vs. aboveground resources for soil arthropod communities in arable systems.

Soil arthropod species have been assigned to distinct trophic groups, including herbivores, detritivores, fungivores, bacterivores and predators (Bardgett, 2005). However, assigning soil arthropods to distinct trophic levels may be oversimplistic as they form a continuum of feeding strategies with high degree of omnivory (Digel et al., 2014). Further, food resources of species vary markedly within taxonomic groups, including Collembola (Chahartaghi et al., 2005), Oribatida (Schneider et al., 2004) and Gamasida (Klarner et al., 2013), suggesting that species-specific information is needed to understand soil food web structure and the contribution of soil animals to element fluxes. 
Stable isotope analysis is a useful tool to identify feeding strategies of soil arthropods. Natural variations in ${ }^{15} \mathrm{~N} /{ }^{14} \mathrm{~N}$ ratios reflect the trophic position of species and ${ }^{13} \mathrm{C} /{ }^{12} \mathrm{C}$ ratios allow tracing basal resources (Petersen and Fry, 1987; Ponsard and Arditi, 2000; Post, 2002). In particular, plant material with distinct ${ }^{13} \mathrm{C}$ signature allows timeintegrated quantification of the incorporation of $C$ into soil food webs, for instance by application of ${ }^{13} \mathrm{C}$ enriched litter resources (Pollierer et al., 2007), and labelling of belowground resources via feeding plants with ${ }^{13} \mathrm{CO}_{2}$ allows following the incorporation of root-derived resources into soil food webs (Leake et al., 2006; Eissfeller et al., 2013). Moreover, planting of C4 plants at locations with C3 plant history (or vice versa) allows tracing the incorporation of root-derived resources into soil food webs. Based on this approach the turnover of soil C (Arrouays et al., 1995), the use of C resources by earthworms (Spain et al., 1990; Martin et al., 1992) and the utilization of C resources by soil arthropods in arable fields has been investigated (Albers et al., 2006, von Berg et al., 2010), but to the best of our knowledge this is the first study quantifying the contribution of (C4-derived) plant residue resources of below- and aboveground origin to soil arthropod nutrition.

We established experimental fields planted with maize (C4) or wheat (C3) on an arable field site with a history of C3 plants. Maize shoot residues were added to half of the maize and wheat plots and incorporation of shoot residue- and root-derived $C$ into soil arthropods was quantified by analyzing variations in ${ }^{13} \mathrm{C} /{ }^{12} \mathrm{C}$ ratios. Incorporation of maize $C$ into soil arthropods was followed for one year to assess (1) if the proportion of maize $\mathrm{C}$ in soil arthropods increases with time due to continuous replacement of body tissue $C$ by maize $C$, and (2) if plant $C$ enters the soil arthropod food web predominantly via shoot residue- or root-derived resources. Whenever possible we identified soil arthropods to species level to account for species-specific feeding strategies allowing detailed insight into the relative contribution of above- vs. belowground resources for nourishing soil food webs and its variation in time. 


\section{Materials and Methods}

\section{Study site}

The study site is located in the vicinity of Göttingen (Lower Saxony, Germany) on a plain of the river Leine $160 \mathrm{~m}$ a.s.l. $\left(51^{\circ} 33^{\prime} 37^{\prime \prime} \mathrm{N}, 9^{\circ} 53^{\prime} 46^{\prime \prime} \mathrm{E}\right)$. Mean annual temperature is $8.7^{\circ} \mathrm{C}$ and mean annual precipitation $645 \mathrm{~mm}$. The soil is characterized as haplic luvisol formed by long term agricultural management. More details on the study site are given in Kramer et al. (2012).

On an arable field with C3 plant history two adjacent rows of $24 \times 240$ m were established and planted with winter wheat (Triticum aestivum, C3; sown in October 2008) and maize (Zea mays, C4; April 2009), respectively. Each row was divided into ten plots of $24 \times 24 \mathrm{~m}$. After the first vegetation period (August 2009) wheat was harvested and shoot residues were removed from the experimental plots. After harvest of maize cobs (October 2009) maize shoots (without cobs) were cut into pieces of ca. $1 \mathrm{~cm}^{2}$ and added to the surface of half of the maize and wheat plots. The treatment simulated residue addition corresponding to the biomass of maize shoots at the study site $(0.8 \mathrm{~kg}$ dry weight

$\mathrm{m}^{-2}$ ). We established four treatments: maize with $(\mathrm{M}+)$ and without shoot residues $(\mathrm{M}-)$, and wheat with $(\mathrm{W}+)$ and without shoot residues $(\mathrm{W}-)$. The treatments represented $\mathrm{C} 4$ inputs either both below- and aboveground $(\mathrm{M}+)$, only belowground $(\mathrm{M}-)$, only aboveground $(\mathrm{W}+)$ or no $\mathrm{C} 4$ input at all $(\mathrm{W}-)$. Maize shoot residues remained on the soil surface during winter and were tilled into the soil in spring 2010 as is common practice in arable land; tilling also mixed root residues of maize and wheat into the soil. After tilling and seedbed preparation, maize and summer wheat were sown the respective plots.

\section{Sampling and analysis of stable isotopes}

In July 2009 and in July 2010, 2 and 14 months after seeding of maize, respectively, two soil samples were taken per plot to a depth of $10 \mathrm{~cm}$ using a stainless steel corer of $20 \mathrm{~cm}$ diameter. Soil meso- and macrofauna were extracted by heat with temperature gradually increasing from 25 to $55^{\circ} \mathrm{C}$ during 10 days (Kempson et al., 1963), transferred to saturated $\mathrm{NaCl}$ solution and kept at $-10^{\circ} \mathrm{C}$ until further processing. Macrofauna species were identified using a dissecting microscope (Stemi 2000, Zeiss, Jena, Germany), 
mesofauna species by using a light microscope (Axioplan, Zeiss, Jena, Germany) allowing 1000x magnification. Schaefer (2010) was used as standard key for the identification of macrofauna; Gamasida, Oribatida and Collembola were identified using Karg (1993), Weigmann (2006) and Hopkin (2007), respectively. In July 2010 samples of wheat and maize leaves were taken, dried at $60^{\circ} \mathrm{C}$ for $72 \mathrm{~h}$ and milled to powder using a ball mill (MM 400; Retsch GmbH, Haan, Germany). Two mg of plant material were weighed into tin capsules and analyzed for ${ }^{13} \mathrm{C} /{ }^{12} \mathrm{C}$ and ${ }^{15} \mathrm{~N} /{ }^{14} \mathrm{~N}$ stable isotope ratios. The $\delta{ }^{13} \mathrm{C}$ signatures of wheat and maize leaves were $-28.31 \pm 0.16 \%$ ond $-12.52 \pm 0.07 \%$, respectively, and were used to estimate the incorporation of maize-derived $C$ into soil animal body mass (see below); $\delta^{15} \mathrm{~N}$ signatures of wheat and maize leaves were $2.93 \pm$ $0.04 \%$ ond $4.96 \pm 0.06 \%$, respectively, and were used to assign taxa to trophic groups (Table S1, Supporting information). Respective $\mathrm{C} / \mathrm{N}$ ratios were $30.7 \pm 0.3$ and $18.3 \pm 0.1$.

Soil arthropods of at least $0.05 \mathrm{mg}$ dry weight body mass were weighed into tin capsules and analysed for ${ }^{13} \mathrm{C} /{ }^{12} \mathrm{C}$ and ${ }^{15} \mathrm{~N} /{ }^{14} \mathrm{~N}$ stable isotope ratios. Due to low body mass in most soil arthropod taxa several individuals had to be pooled. Some taxa were not found in sufficient number in each of the treatments at both sampling dates, resulting in incomplete samples for statistical analyses.

A coupled system of elemental analyser (Eurovector, Milano, Italy) and isotope ratio mass spectrometer (Thermo Delta Vplus, Thermo Fischer, Bremen, Germany) was used for the analysis of stable isotope ratios of ${ }^{13} \mathrm{C} /{ }^{12} \mathrm{C}$ and ${ }^{15} \mathrm{~N} /{ }^{14} \mathrm{~N}$ (Reineking et al., 1993; Langel and Dyckmans, 2014). Isotope ratios were calibrated using V-PDB for ${ }^{13} \mathrm{C}$ and atmospheric nitrogen for ${ }^{15} \mathrm{~N}$. Acetanilide $\left(\mathrm{C}_{8} \mathrm{H}_{9} \mathrm{NO}\right.$, Merck, Darmstadt, Germany) was used for internal calibration. Isotope abundance was expressed using the delta notation as

$\delta^{13} \mathrm{C}$ or $\delta^{15} \mathrm{~N}(\%)=\left(\mathrm{R}_{\text {sample }}-\mathrm{R}_{\text {standard }}\right) /\left(\mathrm{R}_{\text {standard }} \times 1000\right)$,


standard, respectively.

We used body length and $\delta^{15} \mathrm{~N}$ values to assign soil animal taxa to trophic groups. Taxa of less than $2 \mathrm{~mm}$ body length were assigned to mesofauna, larger taxa to macrofauna. Taxa with $\delta^{15} \mathrm{~N}$ exceeding that of the crop at the respective plot by less than $1.6 \%$ where assigned to decomposers, soil animals with higher $\delta^{15} \mathrm{~N}$ values were assigned 
to predators, resulting in four trophic groups, i.e. macrofauna decomposers, macrofauna predators, mesofauna decomposers and mesofauna predators (Table S1).

\section{Calculations and statistical analyses}

We used a two-source mixing model (Martin et al. 1992) to calculate the incorporation of maize $\mathrm{C}$ in soil animals as

$$
X_{\text {maizec }}=\left[\left(\delta^{13} C_{\text {sample }}-\delta^{13} C_{W-}\right) /\left(\delta^{13} C_{\text {maize }}-\delta^{13} C_{\text {wheat }}\right)\right] \times 100 \text {, }
$$

with $\mathrm{X}_{\text {maizec }}$ representing the proportion of maize $\mathrm{C}$ in soil animal body tissue [in $\% \pm$ standard error of the mean (SEM)], $\delta^{13} \mathrm{C}_{\text {sample }}$ representing the ${ }^{13} \mathrm{C}$ signature of single soil animal taxa extracted at the $\mathrm{W}+, \mathrm{M}$ - or $\mathrm{M}+$ plots and $\delta{ }^{13} \mathrm{C}_{\mathrm{W}}$ - the ${ }^{13} \mathrm{C}$ signature of the respective taxon extracted from $\mathrm{W}$ - plots; $\delta^{13} \mathrm{C}_{\text {maize }}$ and $\delta^{13} \mathrm{C}_{\text {wheat }}$ represent the natural ${ }^{13} \mathrm{C}$ signatures of maize and wheat, respectively. The results represent the relative proportion of maize $\mathrm{C}$ in the body tissue of soil arthropod taxa without considering the biomass of the different taxa.

To test for differences in $\mathrm{C}$ incorporation with time we applied a linear mixed effects model fit by maximum likelihood with sampling date (July 2009, July 2010) as the independent factorial variable and the proportion of maize $C$ in soil taxa $\left(X_{\text {maizec }}\right)$ as the dependent continuous variable; species identity and trophic group affiliation (macrofauna decomposer, macrofauna predator, mesofauna decomposer, mesofauna predator) were included into the model separately with one being treated as independent factorial variable while the other was treated as random factor, and vice versa. Further, we used single-factor analysis of variance (ANOVA) with sampling date as independent factorial variable and $X_{\text {maizec }}$ as dependent continuous variable, followed by Tukey's HSD test for comparison of means (significance level at $p<0.05$ ), for every taxon to test for speciesspecific differences. Only soil arthropods extracted from the M- plots in 2009 and 2010 were included in this analysis.

To identify preferences in resource utilization between soil animals we applied a linear mixed effects model fit by maximum likelihood with Treatment $\left(W_{+}, M_{-}, M_{+}\right)$as independent factorial variable and $X_{\text {maizec }}$ of each taxon as dependent continuous variable. Again species identity and trophic group affiliation were included as random factor into the model separately with one being included as independent factorial 
variable while the other treated as random factor and vice versa. We used single-factor ANOVA and Tukey's HSD test with treatment as independent factor and $X_{\text {maizec }}$ as dependent factor separately for every taxon to test for species-specific differences. Only soil arthropods extracted in July 2010 were included in this analysis.

Statistical calculations were performed using R Version 3.1.1 (R Core Team, 2013) including the packages Multcomp (Hothorn et al., 2008), NLME (Pinheiro et al., 2013) and Effects (Fox, 2003).

\section{Results}

\section{Changes in incorporation of root-derived maize $\mathrm{C}$ with time}

Across all taxa the average proportion of root-derived maize $\mathrm{C}$ in the body tissue of soil arthropods in the $M$ - treatment increased from $25.9 \pm 1.5 \%$ in July 2009 to $31.6 \pm$ $3.4 \%$ in July $2010\left(F_{1,105}=340.3, P<0.0001\right.$; Fig. 1$)$, with at the first sampling only rhizodeposit $\mathrm{C}$ of maize plants being available for soil animals, whereas at the second sampling decomposing maize roots from the first growth period being also available. Incorporation of root-derived maize $C$ with time did not differ between trophic groups $\left(F_{3,108}=0.3, P=0.81\right)$, but significantly differed with species identity $\left(F_{27,105}=3.4, P<0.0001\right)$. Independent of trophic or taxonomic group affiliation, incorporation of root-derived maize $\mathrm{C}$ into soil arthropod body tissue followed three patterns:

(1) It significantly increased from 2009 to 2010 in 3 of 27 arthropod taxa including the macrofauna decomposers Polydesmus superus (Diplopoda; $F_{1,8}=8.4, P=0.020$; Fig. 2a) and Cecidomyiidae larvae (Diptera; $\mathrm{F}_{1,3}=36.9, \mathrm{P}=0.0090$ ) and the macrofauna predator Trechus sp. (Coleoptera; $\mathrm{F}_{1,2}=90.4, \mathrm{P}=0.011$; Fig. $2 \mathrm{~b}$ ). Further, there was a trend towards increasing incorporation of root-derived maize $C$ with time in the macrofauna decomposer Ophiodesmus albonanus (Diplopoda; $\mathrm{F}_{1,2}=13.8, \mathrm{P}=0.07$; Fig. 2a) and the mesofauna predator Alliphis siculus (Gamasida; $\mathrm{F}_{1,2}=10.3, \mathrm{P}=0.09$; Fig. 2d). Moreover, there were six taxa with incorporation of maize C increasing from 2009 to 2010 by more than $10 \%$, but the increase was not significant due to the low number of replicates and high variance. Nonetheless, the data suggest an increase in maize-derived $\mathrm{C}$ in body tissue in these species, including the macrofauna decomposer Paederinae (Coleoptera; $F_{1,3}=1.6$, 
$\mathrm{P}=0.29$; Fig. 2a), the macrofauna predators Necrophloeophagus longicornis (Chilopoda; $F_{1,2}=24.1, P=0.13$; Fig. $2 b$ ) and Muscidae larvae (Diptera; $F_{1,2}=2.6, P=0.35$; Fig. $2 b$ ), and the mesofauna predators Pseudosinella alba (Collembola; $\mathrm{F}_{1,2}=29.7, \mathrm{P}=0.12$; Fig. 2d), Lysigamasus sp. (Gamasida; $\mathrm{F}_{1,3}=2.7, \mathrm{P}=0.19$; Fig. 2d) and Pergamasus crassipes (Gamasida; $F_{1,4}=2.7, P=0.18$; Fig. 2d).

(2) Incorporation of root-derived maize $C$ decreased significantly with time in four arthropod taxa including larvae of Staphylinidae (Coleoptera; $F_{1,5}=7.1, P=0.045$; Fig. 2a), the macrofauna predators Meioneta sp. (Araneae; $F_{1,6}=24.8, P=0.0025$; Fig. $2 b$ ) and Lamyctes fulvicornis (Chilopoda; $\mathrm{F}_{1,4}=113.1, \mathrm{P}=0.0004$; Fig. 2b), and the mesofauna decomposer Isotoma viridis (Collembola; $\mathrm{F}_{1,4}=40.3$, $\mathrm{P}=0.0031$; Fig. $2 \mathrm{c}$ ).

(3) In the remaining species there was no significant effect or trend of sampling date and the incorporation of maize C between July 2009 and July 2010 was less than $10 \%$. We therefore assume a similar incorporation of maize-derived $C$ at both sampling dates in these taxa, including the macrofauna decomposer Blaniulus guttulatus (Diplopoda; Fig. 2a), the macrofauna predators Symphylella vulgaris (Symphyla; Fig. 2b), adult Bembidion sp. (Coleoptera; Fig. 2b), Elateridae larvae (Coleoptera; Fig. 2a) and Carabidae larvae (Coleoptera; Fig. 2b), the mesofauna decomposers Protaphorura armata (Collembola; Fig. 2c) and Tectocepheus velatus (Oribatida; Fig. 2c), and the mesofauna predators Lepidocyrtus cyaneus (Collembola; Fig. 2d), and Geholaspis mandibularis (Gamasida; Fig. 2d).

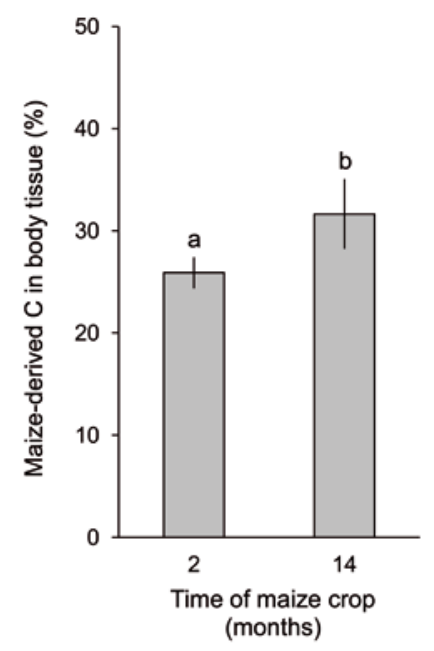

Figure 1: Average proportion of root-derived maize $C$ in soil arthropods in maize fields without shoot residue addition after 2 and 14 months of maize crop, i.e. in July 2009 and July 2010 ( \pm SEM). Bars with different letters indicate significant differences between means ( $p<0.05$, Tukey's HSD). 


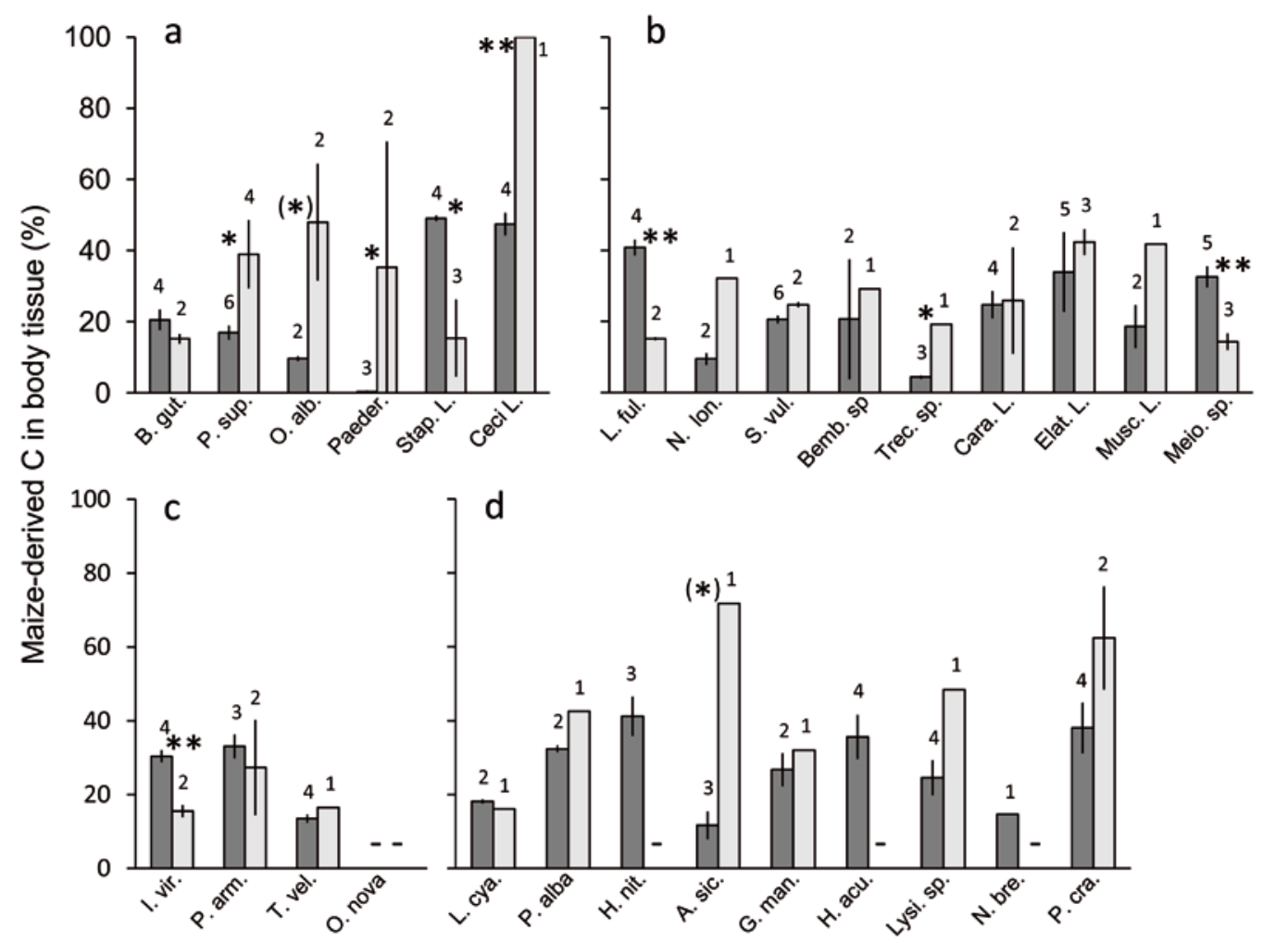

Figure 2: Proportion of root-derived maize $C$ in soil arthropod taxa of (a) macrofauna decomposers, (b) macrofauna predators, (c) mesofauna decomposers and (d) mesofauna predators in maize fields without shoot residue addition after 2 (dark grey) and 14 months (light grey) of maize crop, i.e. in July 2009 and July 2010 ( \pm SEM). Numbers indicate number of replicates per species and sampling. B. gut. = Blaniulus guttulatus; P. sup. = Polydesmus superus; O. alb. = Ophiodesmus albonanus; Paeder. = Paederinae; Stap. L. = Staphylinidae larvae; Ceci. L. = Cecidomyiidae larvae; Musc. L. = Muscidae larvae; L. ful. = Lamyctes fulvicornis; $\mathrm{N}$. Ion. = Necrophloeophagus longicornis; S. vul. = Symphylella vulgaris; Bemb. sp. = Bembidion sp.; Trec. $\mathrm{sp} .=$ Trechus sp.; Cara. L. = Carabidae larvae; Elat. L. = Elateridae larvae; Meio. sp. = Meioneta sp.; I. vir = Isotoma viridis; P. arm. = Protaphorura armata; T. vel. = Tectocepheus velatus; L. cya = Lepidocyrtus cyaneus; P. alba = Pseudosinella alba; H. nit. = Heteromurus nitidus; O. nova = Oppiella nova; A. sic. = Alliphis siculus; G. man. = Geholaspis mandibularis; $\mathrm{H}$. acu. = Hypoaspis aculeifer; Lysi. sp. = Lysigamasus sp.; $\mathrm{N}$. bre. = Nenteria breviunguiculata; $\mathrm{P}$. cra = Pergamasus crassipes; - = missing value; Asterisks indicate level of significance (Tukey's HSD): ${ }^{* * *}=\mathrm{P}<0.001,{ }^{* *}=\mathrm{P}<0.01,{ }^{*}=\mathrm{P}<0.05,{ }^{(*)}=\mathrm{P}<0.1$.

\section{Incorporation of shoot residue- vs. root-derived C}

After one year of maize crop, across all taxa the average proportion of maize $\mathrm{C}$ in soil arthropods was significantly affected by treatment $\left(F_{3,196}=133.4, P<0.0001\right)$; the proportion of maize $C$ in soil arthropods increased from $W+(11.3 \pm 1.4 \%$ of body mass $)$ to $M-(31.6 \pm 3.4 \%)$ and $M+(40.2 \pm 2.6 \%)$, with both maize treatments differing significantly from $W+$ (Fig. 3). Again, incorporation of maize $C$ did not differ significantly between trophic groups $\left(F_{3,196}=0.6, P=0.64\right)$, but with species identity $\left(F_{28,196}=4.5, P<0.0001\right)$. The proportion of shoot residue- and root-derived maize $C$ in soil arthropods varied between 
taxa independent of trophic or taxonomic group affiliation (Fig. 4) and followed four patterns:

(1) Only two taxa preferentially incorporated shoot residue-derived maize C: Muscidae larvae $\left(F_{2,1}=482.7, P=0.032\right)$ with higher incorporation of maize-derived $C$ in $\mathrm{W}_{+}$ and $\mathrm{M}+$ as compared to $\mathrm{M}$ - (Fig. $4 \mathrm{~b}$ ), and Oppiella nova (Oribatida; $\mathrm{F}_{1,4}=100.5, \mathrm{P}=0.0006$ ) with high incorporation of shoot residue-derived maize $\mathrm{C}$ in $\mathrm{W}+$ but no incorporation of maize $\mathrm{C}$ in $\mathrm{M}+$ (no value for $\mathrm{M}-$; Fig. 4c).

(2) Six taxa incorporated significantly higher proportions of root-derived than shoot residue-derived maize $\mathrm{C}$ into their body tissue, i.e. incorporation of maize $\mathrm{C}$ was higher in both maize treatments as compared to $\mathrm{W}+$. These taxa included Symphylella vulgaris $\left(F_{2,12}=20.5, P=0.0001\right.$; Fig. 4b), Carabidae larvae $\left(F_{2,5}=15.6, P=0.0071\right.$; Fig. 4b), Elateridae larvae $\left(F_{2,11}=17.7, \quad P=0.0004\right.$; Fig. 4b), Meioneta sp. $\left(F_{2,3}=30.1, P=0.010\right.$; Fig. 4b), Protaphorura armata $\left(\mathrm{F}_{2,11}=25.4, \mathrm{P}<0.0001\right.$; Fig. $\left.4 \mathrm{c}\right)$, and Tectocepheus velatus $\left(\mathrm{F}_{2,5}=60.3\right.$, $\mathrm{P}=0.0003$; Fig. 4c). In addition, there was a trend towards a preference for root-derived $\mathrm{C}$ in Alliphis siculus ( $F_{2,4}=6.7, P=0.053$; Fig. $\left.4 d\right)$ and Pergamasus crassipes $\left(F_{2,6}=3.8, P=0.087\right.$; Fig. 4d). Furthermore, three more species incorporated more root-derived maize $C$ into their body tissue, but due to low number of replicates and high variances we did not detect a significant effect: Cecidomyidae larvae, Lysigamasus sp. and Pseudosinella alba (Fig. 4a/d).

(3) The proportion of maize $C$ in animal body tissue increased from $W+$ to $M-$ to $M+$ treatments in about half of the arthropod taxa, indicating similar and additive incorporation of shoot residue- and root-derived C. In these taxa, incorporation of maize C was significantly higher in $\mathrm{M}+$ as compared to $\mathrm{W}+$ plots, with $\mathrm{M}$ - being at an intermediate position. The taxa included Blaniulus gutttulatus $\left(F_{2,9}=49.5, P<0.0001\right.$; Fig. 4a), Polydesmus superus $\left(F_{2,9}=6.1, P=0.021\right.$; Fig. $\left.4 a\right)$, Ophiodesmus albonanus $\left(F_{2,6}=9.1\right.$, $\mathrm{P}=0.015$; Fig. 4a), Staphylinidae larvae $\left(\mathrm{F}_{5,2}=6.8, \mathrm{P}=0.029\right.$; Fig. $\left.4 \mathrm{a}\right)$, Lamyctes fulvicornis $\left(F_{2,14}=16.7, P=0.0002\right.$; Fig. $\left.4 b\right)$, and Isotoma viridis $\left(F_{2,8}=5.5, P=0.031 ;\right.$ Fig. $\left.4 c\right)$. Further, in trend incorporation of both shoot residue- and root-derived maize $C$ increased in Necrophloeophagus longicornis $\left(\mathrm{F}_{2,3}=5.5, \mathrm{P}=0.10\right.$; Fig. $\left.4 \mathrm{~b}\right)$.

(4) There was no preference for shoot residue- or root-derived maize $C$ in Lepidocyrtus cyaneus and Paederinae (Fig. 4a/d). 


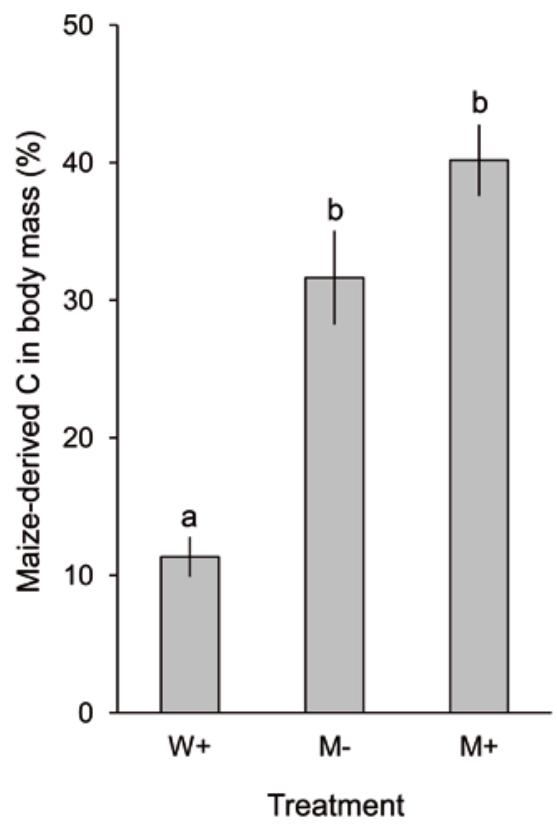

Figure 3: Average proportion of maize $C$ in soil arthropods in July $2010( \pm$ SEM) in wheat fields with residue addition $(\mathrm{W}+)$, and maize fields with $(\mathrm{M}+)$ and without residue addition (M-). Bars with different letters indicate significant differences between means ( $p<0.05$, Tukey's HSD).

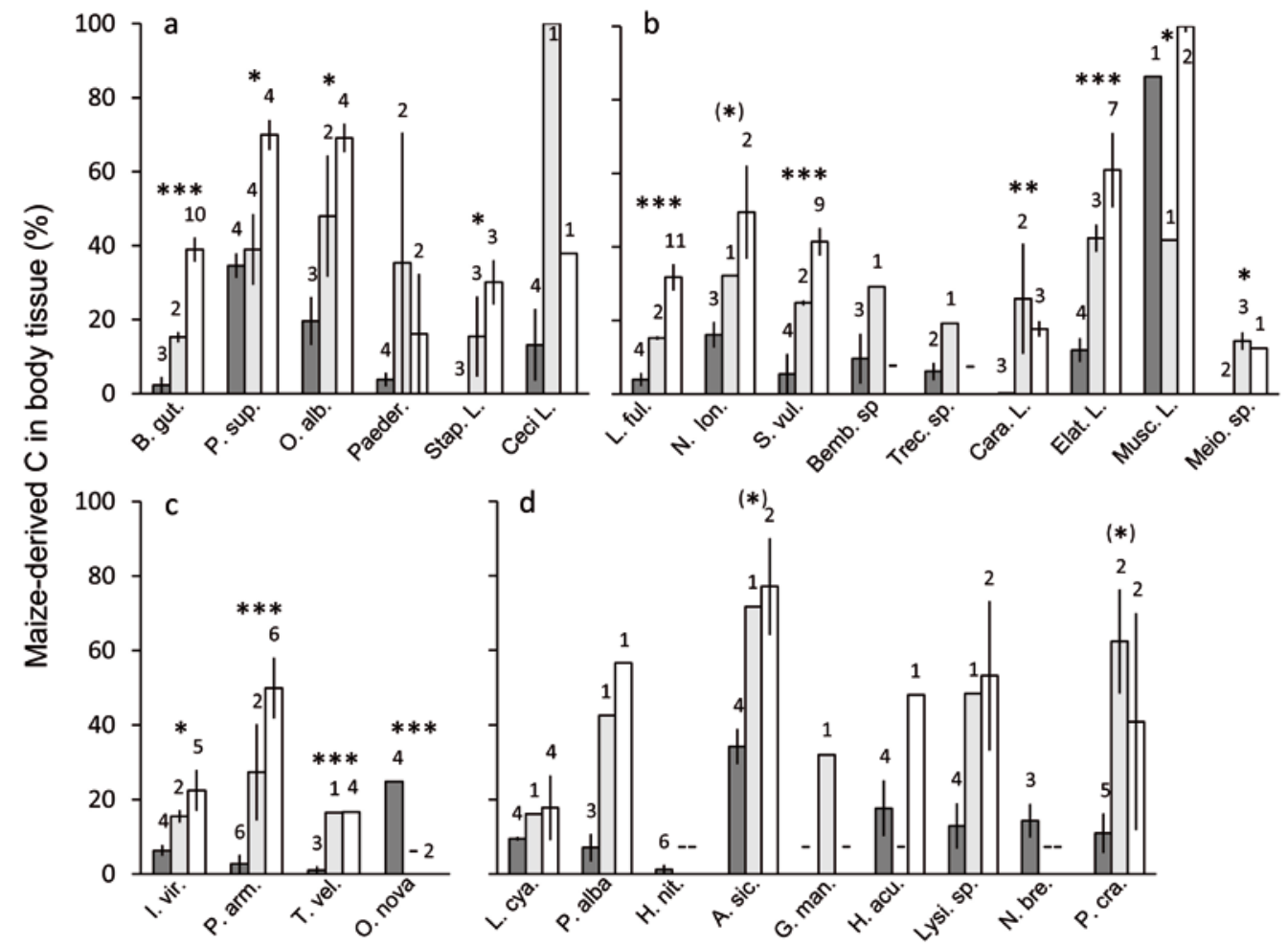

Figure 4: Proportion of root-derived maize $C$ in different trophic groups of ((a) macrofauna decomposers, (b) macrofauna predators, (c) mesofauna decomposers and (d) mesofauna predators in July 2010 ( \pm SEM) in wheat fields with residue addition ( $\mathrm{W}+$, dark grey), and maize fields without $(\mathrm{M}-$-, light grey) and with residue addition $(\mathrm{M}+$, white). Numbers indicate number of replicates per species and treatment. For legend to abbreviations see Fig. 2. 


\section{Discussion}

\section{Changes in incorporation of root-derived maize $\mathrm{C}$ with time}

After two months of maize crop all species except Paederinae (Coleoptera) incorporated root-derived maize $\mathrm{C}$ with the proportion of maize $\mathrm{C}$ ranging from only about 4 to more than $45 \%$ of body tissue C. Averaged across soil arthropod taxa rootderived maize $\mathrm{C}$ accounted for $26 \%$ of soil arthropod $\mathrm{C}$ after two months, suggesting that recently assimilated $C$ quickly enters the soil food web via rhizodeposition, highlighting that root-derived C forms an important resource for soil arthropods in arable systems as suggested earlier (Spain et al., 1990; Albers et al., 2006). The general increase in incorporation of root-derived maize $\mathrm{C}$ into soil arthropods with time, averaging $32 \%$ of soil arthropod $\mathrm{C}$ after 14 month of maize crop, confirmed our first hypothesis, underlining the importance of root-derived C as basal resource of arable soil food webs. In July 2009 old $\mathrm{C}$ in the body tissue of soil arthropods was increasingly replaced by new root-derived maize C with time, while in July 2010 the percentage of maize $C$ in body tissue reliably represents the percentage of maize $C$ in the species' diet. Presumably, populations of most species consisted of individuals of subsequent generations in July 2010 as compared to July 2009, since most species in arable fields are short-lived (e.g., Collembola). Further, in many longer lived species we investigated larvae which likely developed during the experiment and therefore their stable isotope ratios reliably reflect incorporation of maize $\mathrm{C}$.

However, soil arthropods continued to incorporate C3-derived resources after more than one year of maize crop. This is in line with earlier studies documenting incomplete replacement of C3-derived C even after cropping C4 plants for two (Albers et al., 2006) or even 27 years (Scheunemann et al., 2010). Incorporation of both fresh C4 and old C3 resources indicates that soil arthropods in arable fields depend on more than one basal resource.

The proportion of root-derived $\mathrm{C}$ in soil arthropod tissue increased, decreased or remained constant between July 2009 and 2010, with the response being independent of trophic or taxonomic group. In half of the taxa the proportion of root-derived maize $\mathrm{C}$ in soil animal tissue increased with time, proving the importance of root-derived resources 
for soil arthropod nutrition. As the proportion of root-derived maize $C$ increased in both decomposer and predator soil arthropods, root resources entered the soil food web directly via root feeding (e.g., in P. superus and Muscidae larvae), indirectly via feeding on soil fungi [e.g., in Cecidomyiidae larvae, see also Scharroba et al. (2012) and Kramer et al. (2013)] or predation on soil arthropods (e.g., in Trechus sp., A. siculus and N. Iongicornis). Importantly, while in July 2009 incorporated maize C was entirely derived from rhizodeposits, in July 2010 dead maize roots originating from the previous vegetation period may have contributed to the diet of decomposer species in addition to rhizodeposits (e.g., in the Diplopoda P. superus and O. albonanus). Soil arthropod taxa with similar proportions of root-derived C in body tissue in 2009 and 2010 were mainly short lived taxa and larvae, suggesting that consecutive generations rely on similar resources. Supporting this assumption, Albers et al. (2006) found similar proportions of maize $\mathrm{C}$ incorporated into short-lived taxa such as Collembola after six and 18 months of maize cultivation. In our study incorporation of maize $C$ decreased with time in four taxa, indicating higher availability of C3 resources in 2010 than in 2009. Decreasing proportions of root-derived C in large and/or mobile soil arthropod taxa including L. fulvicornis and Staphylinidae larvae likely were related to the high mobility of these species allowing migration into the maize plots from the surrounding wheat field or field margin (Pfiffner and Luka, 2000; Noordijk et al., 2010). Feeding on alternative resources may lead to an underestimation of maize $\mathrm{C}$ incorporation into mobile species, therefore our estimation is conservative with the real importance of root-derived resources for arable soil food webs probably being higher.

\section{Incorporation of shoot residue- and root-derived C}

Supporting our second hypothesis, the proportion of root-derived maize C incorporated into soil arthropods strongly exceeded that of shoot residue-derived maize C, with root-derived maize $C$ contributing on average more than $30 \%$ to soil arthropod body tissue, while shoot residue-derived maize $\mathrm{C}$ was only incorporated to less than $12 \%$. This suggests that in arable systems with aboveground residues mixed into the soil, rootderived outweigh shoot residue-derived resources in fuelling soil food webs by a factor of about two. In contrast to earlier studies (Lehman et al., 2008; Wang et al., 2012) maize 
residues added were rich in nitrogen (C-to- $\mathrm{N}$ ratio of 18.3 ) and lost $>70 \%$ of their mass within 6 months as indicated by litterbag experiments conducted parallel to the present study (N. Scheunemann, unpubl. data). The higher root biomass of wheat as compared to maize (Kramer et al., 2012) may have influenced the incorporation of shoot residuederived maize $C$ into soil arthropods in $W+$ plots. However, the lack of increased incorporation of maize $\mathrm{C}$ in many species in $\mathrm{M}+$ as compared to $\mathrm{M}$ - treatments indicates that maize shoot residues only serve as additional resource, while most of the studied soil arthropods mainly rely on root-derived $C$ resources. This underlines the significant importance of root-derived resources for food webs of arable systems, resembling food webs of forest soils (Caner et al., 2004, Pollierer et al., 2007). Supporting the low importance of shoot residue-derived resources for arable soil food webs, addition of maize shoot residues did not increase soil arthropod abundance at the study site, whereas root-derived resources beneficially affected soil arthropod abundance (Scheunemann et al., 2015).

The increase in incorporation of maize $C$ from $W+$ to $M-$ and $M+$ treatments highlights the flexibility of feeding strategies of soil arthropods in arable fields. Further, similar high incorporation of maize $\mathrm{C}$ into predator and decomposer taxa suggests that in arable fields the flow of $\mathrm{C}$ is not only channelled from meso- and macrofauna decomposers to predators, but also via prey groups not included in our analyses, presumably nematodes. Supporting this assumption, herbivorous nematodes reached high densities at our study site in July 2010 (Scharroba et al., 2012), and the studied predators were dominated by Gamasida and Collembola which have been shown to heavily prey on nematodes (Read et al., 2006; Klarner et al., 2013; Heidemann et al., 2014).

It has been shown that in the long term soil animals (in particular earthworms) rely on $\mathrm{C}$ resources derived from vegetation periods years to decades before (Briones et al., 2005; Scheunemann et al., 2010) and as a consequence our results may overestimate the importance of recently added resources, i.e. rhizodeposits, for soil animal nutrition. However, at our field site Pausch et al. (2012) showed that in soil microorganisms the availability of recent $C$ resources exceed those of more than one year old $C$ by a factor of seven. Recently added C resources therefore are of high importance for higher trophic 
levels of the soil food web (i.e., meso- and macrofauna), since soil arthropods rely directly or indirectly on soil microorganisms.

\section{Species specific resource utilization}

Incorporation of shoot residue- and root-derived resources into soil arthropods was independent of trophic or taxonomic group; rather, it was species-specific and in accordance to the generally low contribution of shoot residue-derived resources to soil arthropod body $\mathrm{C}$ only few taxa incorporated shoot residue-derived maize C. For instance, A. siculus and O. nova, previously documented to feed on nematodes (Koehler, 1997) and soil fungi (O. nova; Schneider and Maraun, 2005), incorporated high proportions of maize $\mathrm{C}$ in $\mathrm{W}+$ fields, suggesting that their prey relies on shoot residue-derived resources. However, while $A$. siculus incorporated shoot residue-derived $C$ in $\mathrm{W}+$ as well as $\mathrm{M}+$ fields, $O$. nova only incorporated maize $\mathrm{C}$ in $\mathrm{W}+$ but not in $\mathrm{M}+$ fields, indicating that the importance of shoot residue-derived $C$ in $O$. nova varies with crop species. Presumably, $O$. nova feeds on microorganisms involved in litter decomposition in wheat fields, with these species being absent or rare in maize fields, resulting in $O$. nova switching its diet from nematodes in wheat to soil fungi in maize fields. Exploitation of different basal resources in wheat and maize fields was common at the study site highlighting the dominance of generalist feeders (see below). Muscidae larvae incorporated high proportions of shoot residue-derived $\mathrm{C}$. Due to high ${ }^{15} \mathrm{~N}$ signatures Muscidae larvae were assigned to predators, but their reliance on shoot residue-derived $\mathrm{C}$ indicated feeding on saprotrophic fungi, supporting the view of soil dwelling Diptera larvae living predominantly as decomposers feeding on decaying litter (Frouz, 1999).

About $50 \%$ of the taxa predominantly relied on root-derived resources. In contrast to Muscidae larvae, preferential incorporation of root-derived $C$ by Cecidomyiidae larvae likely was due to feeding on living or decaying roots. The contrasting incorporation patterns indicate niche differentiation among saprophagous Diptera larvae in arable fields with limited availability of resources (Frouz, 1999; Nielsen and Nielsen, 2002). Fungivory is common in small-sized Staphylinidae (Dennis et al., 1991) and incorporation of rootderived $C$ in Paederinae and Staphylinidae larvae therefore likely is due to feeding on fungi which heavily incorporated root $\mathrm{C}$ at the studied arable field (J. Pausch et al., under 
review). Among predatory taxa, Carabidae larvae, Elateridae larvae, P. alba, Lysigamasus sp. and P. crassipes preferentially incorporated root- as compared to shoot-derived maize C, suggesting that their prey taxa predominantly live on root-derived resources. Nematodes substantially contribute to the diet of predatory Collembola and Gamasida (Klarner et al., 2013; Heidemann et al., 2014); therefore, the high proportions of rootderived $\mathrm{C}$ in these species suggest predation on nematodes, in particular those feeding on roots. In addition, large bodied predators such as Carabidae larvae presumably heavily preyed on Collembola or other small soil arthropods that rely on root-derived resources.

Of the taxa that preferred root-derived over shoot residue-derived resources, $T$. velatus, I. viridis and Meioneta sp. incorporated only low proportions of maize C. Tectocepheus velatus primarily feeds on litter in forests (Schneider et al., 2004; Perdomo et al., 2012), whereas I. viridis predominantly feeds on fungi (Berg et al., 2004). However, avoidance of shoot residue-derived $\mathrm{C}$ and low incorporation of root-derived $\mathrm{C}$ indicates that both species exploit alternative resources other than maize residues, potentially old C3 resources remaining in the soil from crops prior to maize plantation (Scheunemann et al., 2010). Meioneta sp. is a small spider that builds its nets near the soil surface, indicating that surface active Collembola, such as $I$. viridis, $H$. nitidus and L. cyaneus, are the most important prey explaining its low incorporation of maize $C$. Both $H$. nitidus and $L$. cyaneus incorporated less than $20 \%$ maize C in July 2010, without preferring shoot residue- or root-derived C. Potentially, they fed on algae (Buse et al., 2013) or relied on old soil C3 resources.

About $40 \%$ of the studied taxa incorporated both shoot residue- and root-derived $C$ without clear preferences suggesting that they depend on both resources. Generalist feeding and omnivory are common in soil food webs (Scheu and Setälä, 2002; Wolkovich et al., 2014; Digel et al., 2014) and this applies in particular to arable fields characterized by strong disturbance and variation in resource inputs during the year (Vreeken-Buijs et al., 1994; Postma-Blaauw et al., 2010). Of these species, most incorporated shoot residuederived $C$ in wheat as well as maize fields. The macrofauna predators N. longicornis, Bembidion sp. and Trechus sp. predominantly rely on small soil invertebrates as prey, and incorporation of shoot residue- as well as root-derived maize $\mathrm{C}$ indicates a wide and variable prey spectrum in these predators. The smaller species L. fulvicornis (mainly 
juveniles), $H$. aculeifer and $N$. breviunguiculata are generalist predators that have been documented to feed on a variety of small prey including nematodes, Collembola and soft bodied mites (Buryn and Brandl, 1992; Read et al., 2006; Klarner et al., 2013), thereby incorporating both shoot residue- and root-derived C. Moreover, incorporation of shoot residue- and root-derived $C$ in $P$. superus, $O$. albonanus and $B$. guttulatus suggests that diplopods not only rely on aboveground litter resources (Semenyuk and Tiunov, 2011), but also feed on belowground plant resources, presumably living roots (Gunn and Cherrett, 1993) or fungal hyphae incorporating root-derived resources (Crowther et al., 2011).

Notably, we found four taxa that incorporated shoot residue- and root-derived maize $\mathrm{C}$ in $\mathrm{M}+$ but hardly incorporated shoot residue-derived $\mathrm{C}$ in the $\mathrm{W}+$ treatment, i.e. Staphylinidae larvae, B. guttulatus, S. vulgaris and $P$. armata. This suggests that at least for some taxa feeding on shoot residue-derived resources varies with habitat conditions, likely due to the presence of more palatable $C$ resources in wheat fields. Presumably, these taxa are able to choose different resources or adapt to changes in resource availability. For example, the Collembola species $P$. armata presumably heavily fed on fine wheat roots rather than shoot residues of maize in the $W+$ treatment, but incorporated both shoot residue- and root-derived maize $C$ in the $M+$ treatment, potentially due to switching to feed on maize roots as well as saprotrophic fungi in the $M+$ treatment (Endlweber et al., 2009; Haubert et al., 2009).

\section{Conclusion}

Results of the present study proved root $\mathrm{C}$ of maize to be incorporated rapidly into the majority of soil arthropod taxa, suggesting that, similar to temperate forests and grasslands, soil food webs of arable systems predominantly rely on root-derived resources. Quantification of the incorporation of root and shoot $C$ into the soil animal food web suggested the importance of root-derived resources to outweigh that of shoot residue-derived resources roughly by a factor of two. Notably, however, the importance of shoot residue- and root-derived resources varied between species irrespective of trophic position and taxonomic group affiliation, highlighting that for understanding the 
flux of carbon through soil food webs they have to be resolved at the level of species. Future studies therefore should focus on species-specific differences in feeding strategies even in such a uniform habitat like an arable field where generalist feeding is widespread. Overall, the results indicate that at least in the short term removal of crop residues, e.g. for biofuel production, only little affects the structure and functioning of soil food webs and may be compensated by fostering the input of root-derived resources.

\section{Acknowledgements}

We thank Reinhard Langel (Kompetenzzentrum Stabile Isotope, University of Göttingen) for analysis of stable isotopes. Thanks to Bernhard Klarner and Verena Eißfeller for help in identifying Gamasida and Oribatida, respectively, and to Sarah Zieger for advice in using R. Many students helped in taking samples in the field, harvesting maize and adding maize residues. Financial support was provided by the German Research Foundation (DFG) within the Research Unit "Carbon flow in belowground food webs assessed by isotope tracers" (FOR 918).

\section{References}

Albers, D., Schaefer, M., Scheu, S., 2006. Incorporation of plant carbon into the soil animal food web of an arable system. Ecology 87, 235-245.

Andresen, L.C., Konestabo, H.S., Maraldo, K., Holmstrup, M., Ambus, P, Beier, C., Michelsen, A., 2011. Organic matter flow in the food web at a temperate heath under multifactorial climate change. Rapid Communications in Mass Spectronomy $25,1485-1496$.

Arrouays, D., Balesdent, J., Mariotti, A., Girardin, C., 1995. Modeling organic-carbon turnover in cleared temperate forest soils converted to maize cropping by using C-13 natural-abundance measurements. Plant and Soil 173, 191-196.

Bardgett, R.D., 2005. The Biology of Soil: a community and ecosystem approach., 1st edn.

Oxford University PresS., Oxford. 
Berg, M.P., Stoffer, M., van den Heuvel, H.H., 2004. Feeding guilds in Collembola based on digestive enzymes. Pedobiologia 48, 589-601.

Berg, K. von, Thies, C., Tscharntke, T., Scheu, S., 2010. Changes in herbivore control in arable fields by detrital subsidies depend on predator species and vary in space. Oecologia 163, 1033-1042.

Bradford, M.A., Strickland, M.S., DeVore, J.L., Maerz, J.C., 2012. Root carbon flow from an invasive plant to belowground foodwebs. Plant and Soil 359, 233-244.

Briones, M.J.I., Garnett, M.H., Piearce, T.G., 2005. Earthworm ecological groupings based on ${ }^{14} \mathrm{C}$ analysis. Soil Biology \& Biochemistry 37, 2145-2149.

Buryn, R., Brandl, R., 1992. Are the morphometrics of chelicerae correlated with diet in mesostigmatid mites (Acari)? Experimental and Applied Acarology 14, 67-82.

Buse, T., Ruess, L., Filser, J., 2013. New trophic biomarkers for Collembola reared on algal diets. Pedobiologia 56, 153-159.

Caner, L., Zeller, B., Dambrine, É., Ponge, J.-F., Chauvat, M., Llanque, C., 2004. Origin of the nitrogen assimilated by soil fauna living in decomposing beech litter. Soil Biology \& Biochemistry 36, 1861-1872.

Cebrian, J., Lartigue, J., 2004. Patterns of herbivory and decomposition in aquatic and terrestrial ecosystems. Ecological Monographs 74, 237-259.

Chahartaghi, M., Langel, R., Scheu, S., Ruess, L., 2005. Feeding guilds in Collembola based on nitrogen stable isotope ratios. Soil Biology \& Biochemistry 37, 1718-1725.

Crowther, T.W., Boddy, L., Jones, T.H., 2011. Species-specific effects of soil fauna on fungal foraging and decomposition. Oecologia 167, 535-545.

Dennis, P., Wratten, S.D., Sotherton, N.W., 1991. Mycophagy as a factor limiting predation of aphids (Hemiptera: Aphididae) by staphylinid beetles (Coleoptera: Staphylinidae) in cereals. Bulletin of Entomological Research 81, 25-31.

Digel, C., Curtsdotter, A., Riede, J, Klarner, B., Brose, U., 2014. Unravelling the complex structure of forest soil food webs: higher omnivory and more trophic levels. Oikos 123, 1157-1172.

Eissfeller, V., Beyer, F., Valtanen, K., Hertel, D., Maraun, M., Polle, A., Scheu, S., 2013. Incorporation of plant carbon and microbial nitrogen into the rhizosphere food web of beech and ash. Soil Biology \& Biochemistry 62, 76-81. 
Endlweber, K., Ruess, L., Scheu, S., 2009. Collembola switch diet in presence of plant roots thereby functioning as herbivores. Soil Biology \& Biochemistry 41, 1151-1154.

Fox, J., 2003. Effect displays in R for generalised linear models. Journal of Statistical Software 8, 1-27.

Frouz, J., 1999. Use of soil dwelling Diptera (Insecta, Diptera) as bioindicators: a review of ecological requirements and response to disturbance. Agriculture, Ecosystems and Environment 74, 167-186.

Gunn, A., Cherrett, J.M., 1993. The exploitation of food resources by soil meso- and macrofauna invertebrates. Pedobiologia 37, 303-320.

Haubert, D., Birkhofer, K., Fließbach, A., Gehre, M., Scheu, S., Ruess, L., 2009. Trophic structure and major trophic links in conventional versus organic farming systems as indicated by carbon stable isotope ratios of fatty acids. Oikos 118, 1579-1589.

Heidemann, K., Hennies, A., Schakowske, J, Blumenberg, L., Ruess, L., Scheu, S., Maraun, M., 2014. Free-living nematodes as prey for higher trophic levels of forest soil food webs. Oikos 123, 1199-1211.

Hopkin, S.P., 2007. A Key to the Collembola (Springtails) of Britain and IrelanD., 1st edn. Field Studies CounciL., London.

Hothorn, T., Bretz, F., Westfall, P., 2008. Simultaneous inference in general parametric models. Biometrical Journal 50, 346-363.

Karg, W., 1993. Die Tierwelt Deutschlands 59 - RaubmilbeN., 2nd edn. Gustav Fischer VerlaG., Jena-Stuttgart-New York.

Kempson, D., Lloyd, M., Ghelardi, M., 1963. A new extractor for woodland litter. Pedobiologia 3, 1-21.

Klarner, B., Maraun, M., Scheu, S., 2013. Trophic diversity and niche partitioning in a species rich predator guild - Natural variations in stable isotope ratios $\left({ }^{13} \mathrm{C} /{ }^{12} \mathrm{C}\right.$., ${ }^{15} \mathrm{~N} /{ }^{14} \mathrm{~N}$ ) of mesostigmatid mites (Acarl., Mesostigmata) from Central European beech forests. Soil Biology \& Biochemistry 57, 327-333.

Koehler, H.H., 1997. Mesostigmata (Gamasina, Uropodina), efficient predators in agroecosystems. Agriculture Ecosystems and Environment 62, 105-117. 
Kramer, S., Marhan, S., Haslwimmer, H., Ruess, L., Kandeler, E., 2013. Temporal variation in surface and subsoil abundance and function of the soil microbial community in an arable soil. Soil Biology \& Biochemistry 61, 76-85.

Kramer, S., Marhan, S., Ruess, L., Armbruster, W., Butenschoen, O., Haslwimmer, H., Kuzyakov, Y., Pausch, J., Scheunemann, N., Schoene, J., Schmalwasser, A., Totsche, K.U., Walker, F., Scheu, S., Kandeler, E., 2012. Carbon flow into microbial and fungal biomass as a basis for the belowground food web of agroecosystems. Pedobiologia 55, 111-119.

Kuzyakov, Y., Domanski, G., 2000. Carbon input by plants into the soil. Review. Journal of Plant Nutrition and Soil Science 163, 421-431.

Lal, R., 2004a. Soil carbon sequestration impacts on global climate change and food security. Science 304, 1623-1627.

Lal, R., 2004b. Soil carbon sequestration to mitigate climate change. Geoderma 123, 1-22

Langel, R., Dyckmans, J., 2014. Combined ${ }^{13} \mathrm{C}$ and ${ }^{15} \mathrm{~N}$ isotope analysis on small samples using a near-conventional elemental analyzer/isotope ratio mass spectrometer setup. Rapid Communications in Mass Spectronomy 28, 1019-1022.

Leake, J.R., Ostle, N.J, Rangel-Castro, J.I., Johnson, D., 2006. Carbon fluxes from plants through soil organisms determined by field ${ }^{13} \mathrm{CO}_{2}$ pulse-labelling in an upland grassland. Applied Soil Ecology 33, 152-175.

Lehman, R.M., Osborne, S.L., Rosentrater, K.A., 2008. No differences in decomposition rates observed between Bacillus thuringiensis and non-Bacillus thuringiensis corn residue incubated in the field. Agronomical Journal 100, 163-168.

Martin, A., Balesdent, J., Mariotti, A., 1992. Earthworm diet related to soil organic matter dynamics through ${ }^{13} \mathrm{C}$ measurements. Oecologia 91, 23-29.

Moore, J.C., Berlow, E.L., Coleman, D.C., de Ruiter, P.C., Dong, Q., Hastings, A., Collins Johnson, N., McCann, K.S., Melville, K., Morin, P.J, Nadelhoffer, K., Rosemond, A.D., Post, D.M., Sabo, J.L., Scow, K.M., Vanni, M.J., Wall, D.H., 2004. Detritus, trophic dynamics and biodiversity. Ecology Letters 7, 584-600.

Nielsen, L.B., Nielsen, B.O., 2002. Density and phenology of soil gallmidges (Diptera: Cecidomyiidae) in arable land. Pedobiologia 46, 1-14. 
Noordijk, J, Musters, C.J.M., Dijk, J., Snoo, G.R., 2010. Invertebrates in field margins: taxonomic group diversity and functional group abundance in relation to age. Biodiversity and Conservation 19, 3255-3268.

Pausch, J., Kuzyakov, Y., 2012. Soil organic carbon decomposition from recently added and older sources estimated by $\delta^{13} \mathrm{C}$ values of $\mathrm{CO}_{2}$ and organic matter. Soil Biology \& Biochemistry 55, 40-47.

Perdomo, G., Evans, A., Maraun, M., Sunnucks, P., Thompson, R., 2012. Mouthpart morphology and trophic position of microarthropods from soils and mosses are strongly correlated. Soil Biology \& Biochemistry 53, 56-63.

Petersen, B.J., Fry, B., 1987. Stable isotopes in ecosystem studies. Annual Reviews in Ecology and Evolution 18, 293-320.

Pfiffner, L., Luka, H., 2000. Overwintering of arthropods in soils of arable fields and adjacent semi-natural habitats. Agriculture, Ecosystems and Environment 78, 215222.

Pinheiro, J., Bates, D., DebRoy, S., Sarkar, D., R Development Team, 2013. NLME: Linear and nonlinear mixed effects models. $\mathrm{R}$ package version 3.1-111.

Pollierer, M.M., Dyckmans, J., Scheu, S., Haubert, D., 2012. Carbon flux through fungi and bacteria into the forest soil animal food web as indicated by compound-specific ${ }^{13} \mathrm{C}$ fatty acid analysis. Functional Ecology 26, 978-990.

Pollierer, M.M., Langel, R., Körner, C., Maraun, M., Scheu, S., 2007. The underestimated importance of belowground carbon input for forest soil animal food webs. Ecology Letters 10, 729-736.

Ponsard, S., Arditi, R., 2000. What can stable isotopes $\left(d^{15} \mathrm{~N}\right.$ and $\left.\mathrm{d}^{13} \mathrm{C}\right)$ tell about the food web of soil macro-invertebrates? Ecology 81, 852-864.

Post, D.M., 2002. Using stable isotopes to estimate trophic position: Models, methods, and assumptions. Ecology 83, 703-718.

Postma-Blaauw, M.B., De Goede, R.G.M., Bloem, J., Faber, J.H., Brussaard, L., 2010. Soil biota community structure and abundance under agricultural intensification and extensification. Ecology 91, 460-473.

R Core Team, 2013. R: A language and environment for statistical computing. $R$ Foundation for Statistical Computing. 
Raich, J.W., Schlesinger, W.H., 1992. The global carbon dioxide flux in soil respiration and its relationship to vegetation and climate. Tellus 44B., 81-99.

Read, D.S., Sheppard, S.K., Bruford, M.W., Glen, M., Symondson, W.O.C., 2006. Molecular detection of predation by soil micro-arthropods on nematodes. Molecular Ecology 15, 1963-1972.

Reineking, A., Langel, R., Schikowski, J., $1993 .{ }^{15} \mathrm{~N},{ }^{13} \mathrm{C}$-on-line measurements with an elemental analyser (Carlo Erba, NA 1500), a modified trapping box and a gas isotope mass spectrometer (FINNIGAN, MAT 251). Isotopenpraxis Environmental Health Studies 29, 169-174.

Schaefer, M., 2010. Brohmer - Fauna von Deutschland, 23rd edn. Quelle \& Meyer Verlag, Wiebelsheim.

Scharroba, A., Dibbern, D., Hünninghaus, M., Kramer, S., Moll, J., Butenschoen, O., Bonkowski, M., Buscot, F., Kandeler, E., Koller, R., Krüger, D., Lueders, T., Scheu, S., Ruess, L., 2012. Effects of resource availability and quality on the structure of the micro-food web of an arable soil across depth. Soil Biology \& Biochemistry 50, 1-11.

Scheu, S., Setälä, H., 2002. Multitrophic interactions in decomposer food webs. In: HawkinS., B.A., Tscharntke, T. (eds.), Multitrophic level interactions. Cambridge University Press, Cambridge, pp. 223-264.

Scheunemann, N., Maraun, M., Scheu, S., Butenschoen, O., (2015) The role of shoot residues vs. crop species for soil arthropod diversity and abundance of arable systems. Soil Biology \& Biochemistry $81,81-88$.

Scheunemann, N., Scheu, S., Butenschoen, O., 2010. Incorporation of decade old soil carbon into the soil animal food web of an arable system. Applied Soil Ecology 46, 59-63.

Schneider, K., Maraun, M., 2005. Feeding preferences among dark pigmented fungal taxa ("Dematiacea") indicate limited trophic niche differentiation of oribatid mites (Oribatida, Acari). Pedobiologia 49, 61-67.

Schneider, K., Migge-Kleian, S., Norton, R.A., Scheu, S., Langel, R., Reineking, A., Maraun, M., 2004. Trophic niche differentiation in soil microarthropods (Oribatida, Acari): evidence from stable isotope ratios $\left({ }^{15} \mathrm{~N} /{ }^{14} \mathrm{~N}\right)$. Soil Biology \& Biochemistry 36, 17691774. 
Schneider, T., Keiblinger, K.M., Schmid, E., Sterflinger-Gleixner, K., Ellersdorfer, G., Roschitzki, B., Richter, A., Eberl, L., Zechmeister-Boltenstern, S., Riedel, K., 2012. Who is who in litter decomposition? Metaproteomics reveals major microbial players and their biogeochemical functions. The ISME Journal 6, 1749-1762.

Semenyuk, I.I., Tiunov, A.V., 2011. Isotopic signature $\left({ }^{15} \mathrm{~N} /{ }^{14} \mathrm{~N}\right.$ and $\left.{ }^{13} \mathrm{C} /{ }^{12} \mathrm{C}\right)$ confirms similarity of trophic niches of millipedes (MyriapodA., Diplopoda) in a temperate deciduous forest. Biology Bulletin 38, 283-291.

Spain, A.V., Saffigna, P.G., Wood, A.W., 1990. Tissue carbon sources for Pontoscolex corethrurus (Oligochaeta: Glossoscolecidae) in a sugarcane ecosystem. Soil Biology \& Biochemistry 22, 703-706.

Vreeken-Buijs, M.J., Geurs, M., Ruiter, P.C de, Brussaard, L., 1994. Microarthropod biomass-C dynamics in the belowground food webs of two arable farming systems. Agriculture, Ecosystems and Environment 51, 161-170.

Wang, X., Sun, B., Mao, J., Sui, Y., Cao, X., 2012. Structural convergence of maize and wheat straw during two-year decomposition under different climate conditions. Environmental Science and Technology 46, 7159-7165.

Weigmann, G., 2006. Die Tierwelt Deutschlands Teil 76 - Hornmilben (Oribatida), 1st edn. Goecke \& Evers, Keltern.

Wolkovich, E.M., Allesina, S., Cottingham, K.L., Moore, J.C., Sandin, S.A., de Mazancourt, C., 2014. Linking the green and brown worlds: The prevalence and effect of multichannel feeding in food webs. Ecology 95, 3376-3386. 


\section{Chapter 4}

\section{INCORPORATION OF ROOT C AND FERTILIZER N INTO the Food Web of AN ARAble Field: \\ VARIATIONS WITH FUNCTIONAL GROUP AND ENERGY ChANNEL}

Nicole Scheunemann, Johanna Pausch, Christoph Digel, Susanne Kramer, Anika Scharroba, Yakov Kuzyakov, Ellen Kandeler, Liliane Rueß, Olaf Butenschoen and Stefan Scheu

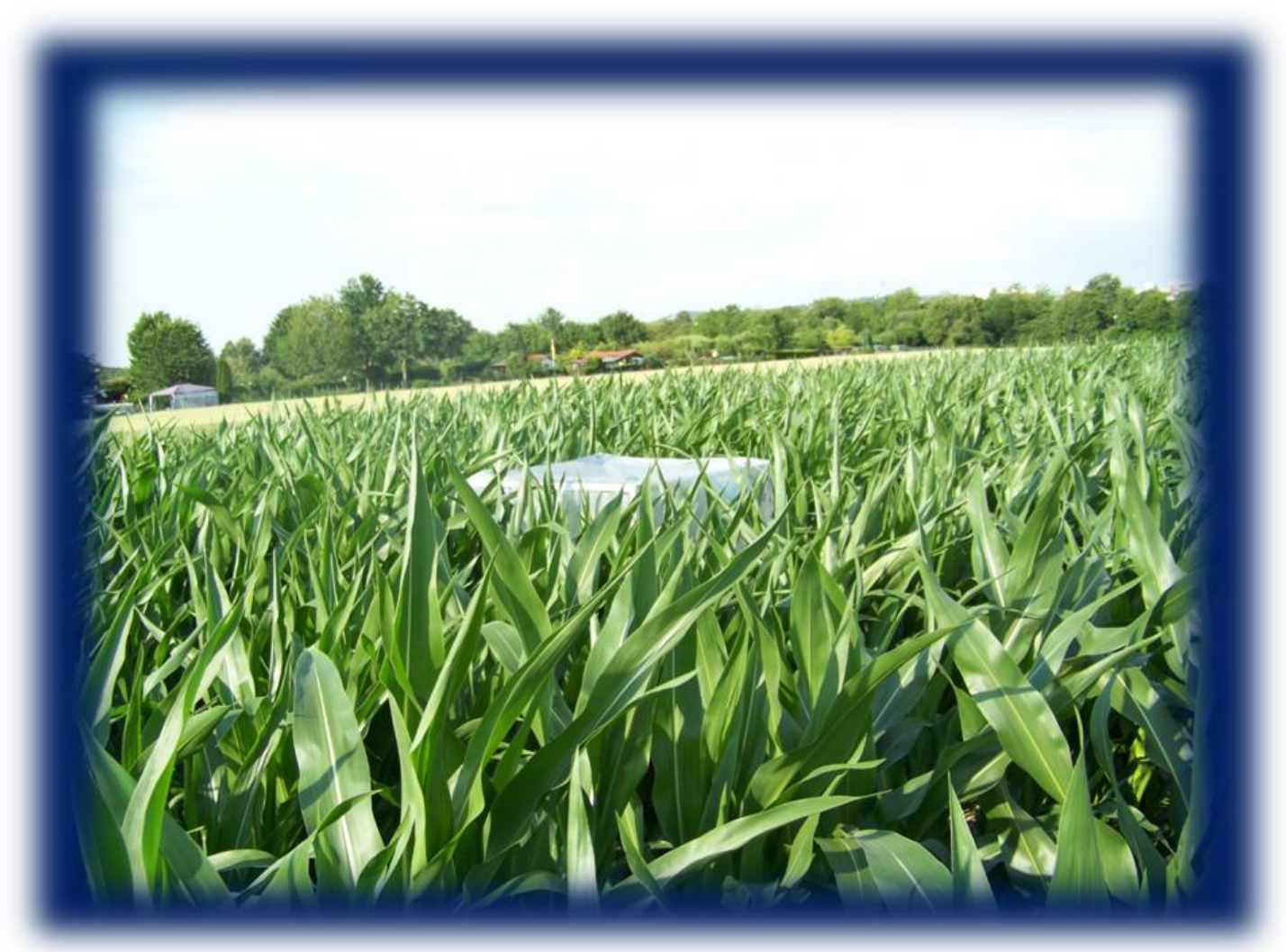

Under Review 


\begin{abstract}
Agroecosystems occupy large areas of the land surface and arable soil food webs are of significant importance for global cycling of carbon $(\mathrm{C})$ and nitrogen $(\mathrm{N})$. In a field experiment we labeled maize plants (Zea mays L.) in ${ }^{13} \mathrm{CO}_{2}$ atmosphere and by $\mathrm{K}^{15} \mathrm{NO}_{3}$ fertilization. During 25 days, the incorporation of ${ }^{13} \mathrm{C}$ and ${ }^{15} \mathrm{~N}$ was traced in plant compartments, soil and soil arthropods, as well as ${ }^{13} \mathrm{C}$ in microbial phospholipid fatty acids (PLFAs) and nematodes. Highlighting the importance of root-derived resources in agroecosystems, ${ }^{13} \mathrm{C}$ was incorporated into all food web compartments, including microorganisms (PLFA), nematodes and arthropods. The amount of incorporated ${ }^{13} \mathrm{C}$ (as compared to unlabeled samples) markedly decreased along the food chain with $\Delta^{13} \mathrm{C}$ decreasing from $500 \%$ in plant roots and $900 \%$ in microbial PLFAs, to less than $40 \%$ in nematodes and arthropods. Incorporation of ${ }^{13} \mathrm{C}$ into fungal PLFAs considerably exceeded that into bacterial PLFAs, highlighting the importance of soil fungi as compared to bacteria in $\mathrm{C}$ cycling. Fertilizer-derived ${ }^{15} \mathrm{~N}$ uniformly increased with time in plant compartments and soil arthropods, indicating that $\mathrm{N}$ is distributed homogeneously in the soil food web. High channeling of both root-derived ${ }^{13} \mathrm{C}$ and fertilizer-derived ${ }^{15} \mathrm{~N}$ to higher trophic levels by fungi, and intensive feeding on fungi by soil animals highlight the central role of saprotrophic fungi in $C$ and nutrient fluxes in soil food webs of arable ecosystems.
\end{abstract}

Key words: macrofauna; mesofauna; pulse labeling; stable isotopes; saprotrophic fungi; trophic level 


\section{Introduction}

At a global scale, soil contains nearly twice as much $\mathrm{C}$ as both the atmosphere and vegetation combined, comprising an approximate amount of $2500 \mathrm{Gt}$ (Lal, 2004a). The fluxes of $\mathrm{C}$ between the soil and atmosphere play a crucial role in regulating the concentration of carbon dioxide in the atmosphere and in turn the Earth's climate (Lal, 2004b; Raich and Schlesinger, 1992). Ample information is available on the total amount of soil C, the different fractions and their residence time (Gaudinski et al., 2000), whereas surprisingly little is known on how the accessibility and complexity of organic $\mathrm{C}$ interact with the soil food web and determine the fate of $C$ in soil. Plant-derived organic $C$ enters the soil food web either belowground via roots and rhizodeposits or aboveground via leaf litter, which differ markedly in their quantity, quality and spatio-temporal accessibility (De Deyn et al., 2008; Kramer et al., 2013; Moll et al., 2015). Rhizodeposits, including sloughed root cells as well as mucilage and root exudates, contain labile C compounds which are easily available to decomposers (Balasooriya et al., 2014; Leake et al., 2006). Leaf litter, in contrast, is rich in structural compounds resisting decomposition (Bahri et al., 2006). The importance of root- and litter-derived resources for the decomposer community has been intensively debated and plant litter has long been considered to be the primary resource of soil food webs (Moore et al., 2004; Schneider et al., 2012). However, evidence is mounting that root-derived resources may be of similar or even higher importance for most soil organisms including microorganisms (Drigo et al., 2010) and meso- and macrofauna (Eissfeller et al., 2013; Pollierer et al., 2007; Ruf et al., 2006). This is especially the case in agroecosystems, where aboveground plant residues are removed at harvest and roots and root exudates remain as the major pathway of plant $C$ to soil biota. Despite the importance of the root channel, little is known on the translocation and flux of root $\mathrm{C}$ within arable soil food webs.

Nitrogen $(\mathrm{N})$ is the most important plant nutrient limiting primary production in agroecosystems. To meet nitrogen demands of crop plants inorganic fertilizer is applied to agroecosystems to increase productivity (Robertson and Vitousek, 2009). However, fertilizer not only increases plant productivity but also impacts the soil food web by decreasing $C$ fluxes within the soil food web, and thereby feeding back on energy fluxes within the whole ecosystem (Lemanski and Scheu, 2014a). Surprisingly, detailed 
knowledge on the fate and pathways of inorganic fertilizer $\mathrm{N}$ in arable soil food webs is lacking, but may help to increase fertilizer efficiency and to reduce the amounts applied to arable fields on a global scale.

Pulse labeling of plants with ${ }^{13} \mathrm{CO}_{2}$ allows tracking the flux of root-derived $\mathrm{C}$ into soil animal food webs (Drigo et al., 2010; Ruf et al., 2006). Previous pulse labeling studies have improved the understanding of spatio-temporal incorporation of root $C$ into soil microorganisms (Leake et al., 2006), soil organic matter pools (Loya et al., 2002) and soil arthropods (Gilbert et al., 2014; Högberg et al., 2010). However, most previous studies on the flux of $\mathrm{C}$ from roots into soil arthropods were conducted in simplified laboratory systems neglecting biotic interactions and the complexity of decomposer food webs (Crotty et al., 2011; Högberg et al., 2010). Incorporation of root C likely differs within and between taxonomic groups as even closely related species differ in their feeding strategy and trophic level (Berg et al., 2004; Klarner et al., 2013; Schneider et al., 2004), resulting in the need to group species according to functional relationships such as feeding guilds rather than taxonomic affiliation. Although natural abundances of $\mathrm{C}$ and $\mathrm{N}$ stable isotopes allow separation of food web compartments according to their feeding strategy, the incorporation and fluxes of $\mathrm{C}$ through the soil food web can only be traced using isotope labeling.

Most previous studies investigating the flux of root-derived $C$ into soil food webs were conducted in forest ecosystems (Bradford et al., 2012; Eissfeller et al., 2013; Pollierer et al., 2012), whereas little is known on the role of root-derived C for soil animal food webs and possible consequences for $C$ sequestration in arable soils. This is surprising given that $40 \%$ of the global ice free land surface is currently used for agriculture (Foley et al., 2005) and the substantial increase of land area used for food production due to the rapidly growing human population (Tilman et al., 2011). Understanding the flux of C into food webs of arable soils and its consequences for $\mathrm{C}$ mineralization and sequestration therefore is essential for predicting the fate of $C$ in the terrestrial realm.

We conducted a short-term pulse labeling experiment to follow the fluxes of $\mathrm{C}$ and $\mathrm{N}$ into the soil animal food web via belowground inputs. We pulse labeled maize plants (Zea mays L.) by adding ${ }^{13} \mathrm{CO}_{2}$ to the atmosphere and $\mathrm{K}^{15} \mathrm{NO}_{3}$ to the soil, and measured the incorporation of ${ }^{13} \mathrm{C}$ and ${ }^{15} \mathrm{~N}$ into plant tissue, soil and the soil food web over a period 
of 25 days. We focused on $\mathrm{C}$ and $\mathrm{N}$ fluxes through soil arthropods, but in addition measured the incorporation of ${ }^{13} \mathrm{C}$ into soil microorganisms (bacteria and fungi) and nematodes as both channel plant-derived $\mathrm{C}$ and fertilizer-derived $\mathrm{N}$ to higher trophic levels. Despite their different origin we expected ${ }^{13} \mathrm{C}$ and ${ }^{15} \mathrm{~N}$ to follow similar incorporation patterns into the soil food web due to soil microorganisms incorporating both and thereby forming a central node for the propagation of these elements into higher trophic levels. In more detail we hypothesized that (1) root-derived C and fertilizerderiver $\mathrm{N}$ is incorporated into all dominant groups of the soil animal food web including meso- and macrofauna of low and high trophic level, (2) lower trophic levels incorporate ${ }^{13} \mathrm{C}$ and ${ }^{15} \mathrm{~N}$ earlier than higher trophic levels due to the delay in channeling $\mathrm{C}$ and $\mathrm{N}$, and (3) the incorporation of ${ }^{13} \mathrm{C}$ and ${ }^{15} \mathrm{~N}$ decreases with increasing trophic level as the diet of predators include prey species not associated with the rhizosphere and rhizosphere microorganisms.

\section{Materials and Methods}

\section{Experimental design}

The experimental arable field site is characterized as a loamy haplic Luvisol located in the vicinity of Göttingen (Lower Saxony, Germany) on a plain of the river Leine $160 \mathrm{~m}$ a.s.I. $\left(51^{\circ} 33^{\prime} 37^{\prime \prime} N, 9^{\circ} 53^{\prime} 46^{\prime \prime} E\right)$. Göttingen is located in the temperate climate zone of central Europe with a mean annual precipitation of $645 \mathrm{~mm}$ and mean annual temperature of $8.7^{\circ} \mathrm{C}$. As part of a long-term experiment the crop was switched from C3 crops to maize (C4) in 2009 with maize roots remaining in the soil after harvest and maize residues being returned to the field after removal of cobs. The subsection of the arable field we used for the present labeling experiment covered an area of $24 \times 24 \mathrm{~m}$, on which four labeling chambers were installed in July 2010. The cambers were installed at randomly selected positions, each containing nine maize plants. Control samples were taken at the day of labeling at a distance of $1.5 \mathrm{~m}$ from the chambers. Labelling chambers consisted of a stainless steel frame base of $1 \times 1 \mathrm{~m}$ size that was inserted into the soil to a depth of $10 \mathrm{~cm}$ as base of the chamber, and an aluminum frame (height $2 \mathrm{~m}$ ) that was covered with translucent LDPE foil. Before closing the chambers, ${ }^{15} \mathrm{~N}$ was added to the 
plots by watering the soil with a solution containing $0.7 \mathrm{~g} \mathrm{~K}^{15} \mathrm{NO}_{3} \mathrm{~m}^{-2}\left(99 \%{ }^{15} \mathrm{~N}\right)$ dissolved in $600 \mathrm{ml} \mathrm{H}_{2} \mathrm{O}$. The annual amount of $\mathrm{N}$ added to the field by fertilization was $11.2 \mathrm{~g} \mathrm{~N} \mathrm{~m}^{-2}$ (Kramer et al., 2012), the added ${ }^{15} \mathrm{~N}$ therefore was assumed to only little affect the labile $\mathrm{N}$ pool in soil, but allowed investigating the incorporation of mineral $\mathrm{N}$ added as fertilizer into the soil food web. After ${ }^{15} \mathrm{~N}$ labelling the soil inside the chambers was covered with plastic foil to ensure that ${ }^{13} \mathrm{C}$ only enters the soil via plant roots. ${ }^{13} \mathrm{C}$ labeling of the plants was achieved after closing the chambers airtight by addition of $\mathrm{H}_{2} \mathrm{SO}_{4}$ to a tracer solution of $16 \mathrm{~g} \mathrm{Na}_{2}{ }^{13} \mathrm{CO}_{3}\left(99 \%{ }^{13} \mathrm{C}\right)$ in $100 \mathrm{ml} \mathrm{H} \mathrm{O}_{2}$ and $4 \mathrm{ml}$ of $1 \mathrm{M} \mathrm{NaOH}$ using a syringe. The emerging ${ }^{13} \mathrm{CO}_{2}$ was circulated in the chambers by a fan for $4 \mathrm{~h}$. After the labeling, the foils and aluminum frames were removed from the field, while the steel frame bases remained in the soil to prevent animals from escaping from the labeled area. Further details on the experimental site and labeling method are given in Kramer et al. (2012) and Riederer et al. (2015), respectively.

\section{Sampling}

Soil samples were taken at day 2, 5, 10 and 25 (referred to later as d2, d5, d10 and d25) after labeling to analyze dynamics of the incorporation of ${ }^{13} \mathrm{C}$ and ${ }^{15} \mathrm{~N}$ into soil microorganisms $\left({ }^{13} \mathrm{C}\right.$ only), nematodes $\left({ }^{13} \mathrm{C}\right.$ only), soil arthropods, plant shoots, roots, and bulk soil. Samples taken at adjacent plots at the day of the labeling served as control for analyzing ${ }^{13} \mathrm{C}$ and ${ }^{15} \mathrm{~N}$ natural abundance. In each labeled plot, two soil samples to a depth of $10 \mathrm{~cm}$ were taken at each sampling date using a stainless steel soil corer (diameter 20 $\mathrm{cm}$ ) for the extraction of soil arthropods, and a soil corer of $2.5 \mathrm{~cm}$ diameter for the extraction of nematodes. Soil arthropods were extracted by heat (Kempson et al., 1963), stored in saturated $\mathrm{NaCl}$ solution at $-10^{\circ} \mathrm{C}$ and identified to the highest taxonomic resolution possible under a dissecting and a light microscope using Schaefer (2010) for identification of macrofauna, and Hopkin (2007), Weigmann (2006) and Karg (1993) for identification of Collembola, Oribatida and Gamasida, respectively. Nematodes were extracted using a modified Baermann method (Ruess, 1995), fixed in cold $4 \%$ formaldehyde solution and separated into trophic groups (plant feeders, bacterial feeders, fungal feeders, omnivores and predators) according to Yeates et al. (1993). In addition, at each sampling date, samples of maize shoots, roots and bulk soil from the 
uppermost $10 \mathrm{~cm}$ were taken, dried at $60^{\circ} \mathrm{C}$ for $72 \mathrm{~h}$, milled to powder using a ball mill (MM 400; Retsch GmbH, Haan, Germany), and analyzed for ${ }^{13} \mathrm{C}$ and ${ }^{15} \mathrm{~N}$. Wheat shoots were sampled from an adjacent experimental field site and analyzed for ${ }^{13} \mathrm{C}$ and ${ }^{15} \mathrm{~N}$.

\section{PLFA analysis}

Incorporation of ${ }^{13} \mathrm{C}$ into soil microbial groups was analyzed in phospholipid fatty acids (PLFAs) of bulk and rhizosphere soil samples. For collection of rhizosphere soil we cut one maize plant per sampling and excavated the roots; soil attached to maize roots was taken as rhizosphere soil and collected by carefully shaking the excavated roots. Bulk soil was collected between the maize rows to a depth of $10 \mathrm{~cm}$ using a Riverside auger (diameter $5 \mathrm{~cm}$, Eijkelkamp, Giesbeek, The Netherlands).

PLFAs from rhizosphere and bulk soil were extracted from $6 \mathrm{~g}$ fresh weight soil according to Frostegard et al. (1991), transformed to fatty acid methyl esters and measured by gas chromatography as described by Kramer et al. (2013). Incorporation of

${ }^{13} \mathrm{C}$ into PLFAs was analyzed after fractionation of fatty acid methyl esters with $\mathrm{Ag}^{+}$ cartridges (6 ml, Supelco, Palo Alto, USA; Kramer et al., 2008), using a gas chromatograph (6890 series, Agilent Technologies, USA) equipped with a capillary column VS-23MS (Varian Medical Systems, Palo Alto, USA; $30 \mathrm{~m} \times 250 \mu \mathrm{m}$, film thickness of $0.25 \mu \mathrm{m}$ ), coupled via a gas chromatography-combustion III Interface (Thermo Finnigan, Waltham, USA) to a Delta Plus XP mass spectrometer (Thermo Finnigan MAT, Bremen, Germany). Fatty acids i15:0, a15:0, i16:0 and i17:0 were used as indicator for Gram positive $\left(\mathrm{Gram}^{+}\right)$

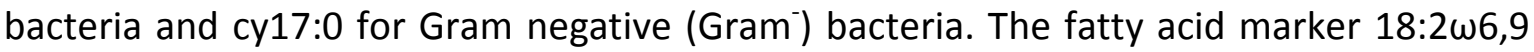
was used as indicator for soil fungi (Ruess and Chamberlain, 2010).

\section{Stable isotope analysis and soil animal food web}

Soil arthropods with a collective body weight of at least $0.05 \mathrm{mg}$ dry weight, plant material and soil were analyzed for ${ }^{13} \mathrm{C} /{ }^{12} \mathrm{C}$ and ${ }^{15} \mathrm{~N} /{ }^{14} \mathrm{~N}$ with a coupled system of an elemental analyzer (NA 1500, Fisons-Instruments, Rodano, Milan, Italy) and isotope ratio mass spectrometer (Delta V plus, Thermofischer, Bremen, Germany; Reineking et al. 1993). Except of Necrophloeophagus longicornis, Scopaeus sp., Paederinae, Aleocharinae 
and Elateridae larvae, individuals of different labeling chambers had to be pooled to obtain sufficient amount of body tissue for stable isotope analysis. For some species the limited material available only allowed single measurements. In addition, some arthropod species were not found at each sampling date in sufficient numbers to allow stable isotope analysis. Nematodes were analyzed for ${ }^{13} \mathrm{C} /{ }^{12} \mathrm{C}$ using an Eurovector elemental analyzer (Eurovector EA3000, Eurovector S.p.A., Milano, Italy) coupled to a Delta V Plus isotope ratio mass spectrometer (Thermo Fisher Scientific, Bremen, Germany; Langel and Dyckmans 2014). The elemental analyzer was fitted with smaller oxidation and reduction reactor tubes (ID $7.8 \mathrm{~mm}$, length $450 \mathrm{~mm}$ ) to allow lower carrier gas flow and increase sensitivity.

For ${ }^{13} \mathrm{C}$ V-PDB and for ${ }^{15} \mathrm{~N}$ atmospheric nitrogen was used as standard. Acetanilide $\left(\mathrm{C}_{8} \mathrm{H}_{9} \mathrm{NO}\right.$, Merck, Darmstadt) was used for internal calibration. Isotope natural abundance was expressed using the delta notation with $\delta^{13} \mathrm{C}$ or $\delta^{15} \mathrm{~N}(\%)=\left[\left(\mathrm{R}_{\text {sample }}\right.\right.$ $\left.\left.R_{\text {standard }}\right) / R_{\text {standard }}\right] \times 1000$ with $R_{\text {sample }}$ and $R_{\text {standard }}$ referring to the ${ }^{13} \mathrm{C} /{ }^{12} \mathrm{C}$ or ${ }^{15} \mathrm{~N} /{ }^{14} \mathrm{~N}$ ratio in samples and standard, respectively.

Natural abundance of ${ }^{15} \mathrm{~N}$ was used to separate arthropod species into trophic levels. ${ }^{15} \mathrm{~N}$ signatures of wheat and maize litter were used for baseline construction and individual species were ascribed to the position along the baseline assuming no shift in ${ }^{13} \mathrm{C}$ signatures between resources and consumers (Fig. S1). Soil arthropod species with a ${ }^{15} \mathrm{~N}$ signature $>1.7 \%$ above the base line were designated as species of high, others as species of low trophic level. The $1.7 \%$ threshold was chosen as it has been shown that decomposer invertebrates typically are less enriched than the common trophic level enrichment of 3.4 \%o (Vanderklift and Ponsard, 2003). This approach bears the risk of oversimplification, but was used as objective way to group species affiliated to different trophic levels. We assume that low trophic level species mainly comprise primary decomposers feeding on leaf litter and root resources, while species grouped as high level species comprise a mixture of fungi feeding secondary decomposers, predators as well as omnivores (Scheu and Falca, 2000; Vanderklift and Ponsard, 2003). Body size was used to separate species into meso- and macrofauna with species $<2 \mathrm{~mm}$ body length being assigned to mesofauna and those $>2 \mathrm{~mm}$ to macrofauna, resulting in four trophic groups: 
low trophic level meso- and macrofauna as well as high trophic level meso- and macrofauna.

\section{Calculations and statistical analyses}

Incorporation of ${ }^{13} \mathrm{C}$ and ${ }^{15} \mathrm{~N}\left(\Delta^{13} \mathrm{C}\right.$ and $\left.\Delta{ }^{15} \mathrm{~N}\right)$ into soil arthropods, nematodes (only

${ }^{13} \mathrm{C}$ ), microbial PLFAs (only ${ }^{13} \mathrm{C}$ ), maize shoots, maize roots and bulk soil was calculated as shift in the isotopic signature as

$\Delta^{13} \mathrm{C}$ or $\Delta^{15} \mathrm{~N}\left[\%\right.$ o $=\mathrm{R}_{\text {labeled sample }}-\mathrm{R}_{\text {unlabeled sample, }}$

with $\mathrm{R}$ the $\delta^{13} \mathrm{C}$ or $\delta^{15} \mathrm{~N}$ signature of the respective taxa, microbial PLFAs, plant tissues or soil, given in \%o \pm standard error of the mean (SEM). Prior to statistical analyses $\Delta^{13} \mathrm{C}$ and $\Delta^{15} \mathrm{~N}$ values were $\log _{10}$-transformed to improve homogeneity of variances; means presented in text, figures and tables represent back-transformed data.

Incorporation of ${ }^{13} \mathrm{C}$ and ${ }^{15} \mathrm{~N}$ into shoots and roots of maize plants and into bulk soil with time was analyzed by linear regression with sampling date $(d 2, d 5, d 10, d 25)$. Changes in the incorporation of ${ }^{13} \mathrm{C}$ into soil microorganisms with time were analyzed using double repeated analysis of variance (ANOVA) with microbial group (fungi, Gram ${ }^{+}$ bacteria, Gram bacteria) and sampling date as repeated factors and soil (bulk, rhizosphere) as independent factor. Differences in ${ }^{13} \mathrm{C}$ and ${ }^{15} \mathrm{~N}$ incorporation between labeling chambers were accounted for by using chamber number as block $(1,2,3,4)$.

Incorporation of ${ }^{13} \mathrm{C}$ and ${ }^{15} \mathrm{~N}$ into nematodes (only ${ }^{13} \mathrm{C}$ ) and meso- and macrofauna was analyzed by linear mixed effects models fit by maximum likelihood, with chamber number (block) and species identity as random effect for nematodes and soil arthropods, respectively. Three linear mixed effects models were calculated with $\Delta^{13} \mathrm{C}$ as dependent continuous variable and (1) nematodes (plant feeders, bacterial feeders, fungal feeders, omnivores and predators) or meso-/macrofauna (low and high trophic level, respectively) as additional random factor to account for effects of sampling date, (2) sampling date as additional random factor to account for effects of nematodes and meso-/macrofauna, and (3) sampling date and nematodes or meso-/macrofauna as independent factor to inspect for interactions of sampling date and nematodes or sampling date and meso/macrofauna, i.e. for differences in incorporation of ${ }^{13} \mathrm{C}$ with time. Differences between means were inspected using Tukey's HSD test at $p<0.05$. 
Statistical calculations were performed using R Version 3.1.1 (R Core Team, 2013) and the packages Multcomp (Hothorn et al., 2008), NLME (Pinheiro et al., 2013) and Effects (Fox, 2003).

\section{Results}

\section{Incorporation of ${ }^{13} \mathrm{C}$ and ${ }^{15} \mathrm{~N}$ into plant tissue and soil}

Enrichment of ${ }^{13} \mathrm{C}$ in maize shoots significantly decreased with time from $352.4 \pm$ $66.2 \%$ at $d 2$ to $207.4 \pm 58.9 \%$ at $d 25\left(F_{1,14}=6.78, p=0.021, r^{2}=0.326\right)$, and from $522.6 \pm$ $64.5 \%$ at $d 2$ to $104.4 \pm 20.4 \%$ at $d 25$ in maize roots $\left(F_{1,14}=46.27, p<0.0001, r^{2}=0.768\right.$; Fig. 1a). ${ }^{13} \mathrm{C}$ enrichment of bulk soil did not significantly change with time $\left(F_{1,14}=0.36, p=0.558\right)$ and averaged $2.1 \pm 0.4 \%$ ocross sampling dates (Fig. S2).

In contrast to ${ }^{13} \mathrm{C},{ }^{15} \mathrm{~N}$ enrichment increased with time in maize shoots $\left(F_{1,14}=5.56\right.$, $\left.p=0.033, r^{2}=0.284\right)$ and roots $\left(F_{1,14}=6.06, p=0.027, r^{2}=0.302\right)$, with an increase from 182.0 $\pm 41.5 \%$ ot $\mathrm{d} 2$ to $694.9 \pm 126.8 \%$ at $\mathrm{d} 25$ in shoots and from $316.1 \pm 110.9 \%$ o at $\mathrm{d} 2$ to $727.8 \pm 66.0 \%$ at $\mathrm{d} 25$ in roots (Fig. 1 b). In bulk soil, ${ }^{15} \mathrm{~N}$ enrichment did not change significantly with time $\left(F_{1,14}=0.01, p=0.957\right)$ and averaged $31.8 \pm 7.4 \%$ ocross sampling dates (Fig. S2).
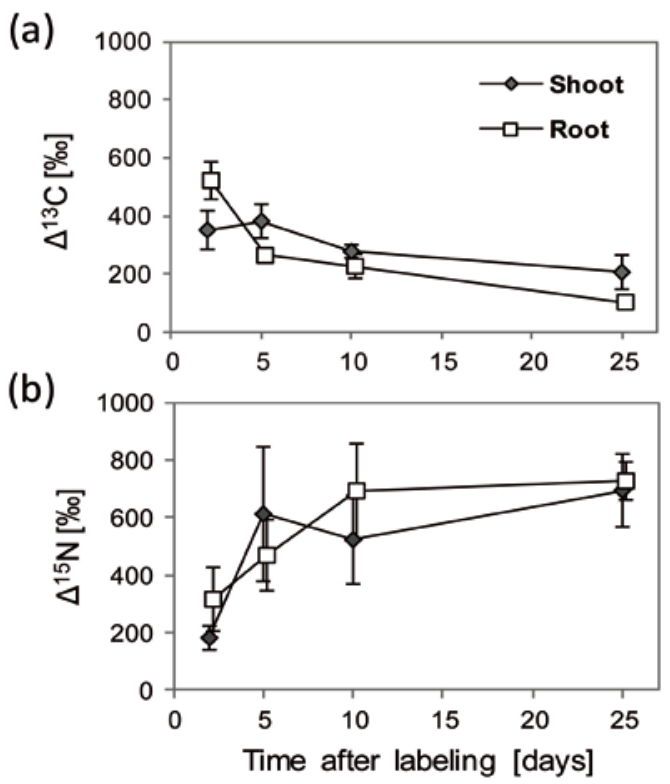

Figure 1: Changes in the incorporation of (a) ${ }^{13} \mathrm{C}$ and (b) ${ }^{15} \mathrm{~N}$ into shoots (black diamonds) and roots (white squares) of maize plants labeled with ${ }^{13} \mathrm{CO}_{2}$ and $\mathrm{K}^{15} \mathrm{NO}_{3}$ during 25 days after labeling (means \pm SEM, $\mathrm{n}=4$ ). 


\section{Incorporation of ${ }^{13} \mathrm{C}$ into soil microorganisms}

Across all sampling dates, incorporation of ${ }^{13} \mathrm{C}$ into microbial PLFAs was strongly affected by soil $\left(F_{1,6}=20.56, p=0.004\right)$ and averaged $170.5 \pm 53.8 \%$ o in the rhizosphere and $35.5 \pm$ $19.0 \%$ in bulk soil. This was consistent in all microbial groups (microbial group $\times$ soil effect: $F_{2,12}=0.29, p=0.752$ ). Incorporation varied significantly between microbial groups $\left(F_{2,12}=823.74, p<0.0001\right)$, with fungi incorporating higher amounts of ${ }^{13} \mathrm{C}$ than $\mathrm{Gram}^{+}$and Gram $^{-}$bacteria, averaging $341.2 \pm 65.7 \%$ o, $11.3 \pm 1.9 \%$ ond $8.1 \pm 1.4 \%$ o across sampling dates, respectively. ${ }^{13} \mathrm{C}$ enrichment significantly decreased with time $\left(F_{3,18}=4.31, p=0.018\right)$ and this did not differ significantly in rhizosphere and bulk soil $\left(F_{3,18}=1.49, p=0.250\right)$. Changes in the ${ }^{13} \mathrm{C}$ incorporation with time varied between microbial groups, and strongly decreased in fungi, while remained more constant in $\mathrm{Gram}^{+}$and Gram ${ }^{-}$bacteria (microbial group $\times$ sampling date interaction; $F_{6,36}=7.50, p>0.0001$ ) in both rhizosphere and bulk soil $\left(F_{6,36}=1.60, p=0.215 ;\right.$ Fig. 2$)$.

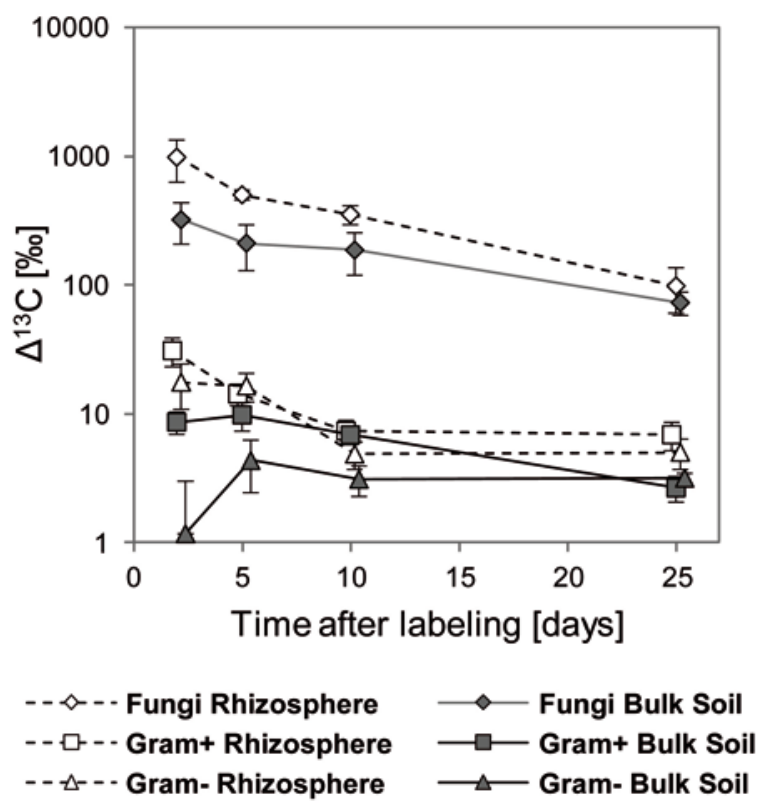

Figure 2: Changes in the incorporation of ${ }^{13} \mathrm{C}$ into microbial PLFAs of the rhizosphere (white symbols) and bulk soil (black symbols) during 25 days after labeling (means $\pm S E M, n=4$ ). 


\section{Incorporation of ${ }^{13} \mathrm{C}$ into nematode trophic groups}

When averaged across sampling dates, incorporation of ${ }^{13} \mathrm{C}$ differed between nematode trophic groups $\left(F_{4,54}=3.43, p=0.014\right)$, with higher incorporation into fungal feeders, plant feeders and omnivores $(9.4 \pm 1.9 \%$, $9.0 \pm 1.7 \%$ o and $9.0 \pm 3.3 \%$, respectively) than into bacterial feeders and predators $(3.8 \pm 0.9 \%$ ond $5.6 \pm 2.0 \%$, respectively).

Over all nematode trophic groups, mean incorporation increased with time $\left(F_{3,51}=3.20\right.$, $p=0.031$; Fig. 3), most evident in fungal feeders and omnivores, with highest incorporation of $16.8 \pm 5.8 \%$ ond $21.8 \pm 9.8 \%$ at day 25 , respectively. In bacterial feeders and predators incorporation of ${ }^{13} \mathrm{C}$ was constant at all sampling dates with only slightly higher enrichment at day 25 than at the other sampling dates, reaching $5.3 \pm 3.7 \%$ ond $8.7 \pm 6.1 \%$, respectively. In contrast, the flux of plant $\mathrm{C}$ was fast into plant feeders, with highest incorporation of $13.0 \pm 4.6 \%$ at day 10 , but decreasing incorporation afterwards. Nevertheless, incorporation dynamics did not differ significantly between nematode trophic groups (nematodes $\times$ sampling date interaction; $F_{12,51}=1.03, p=0.440$ ).

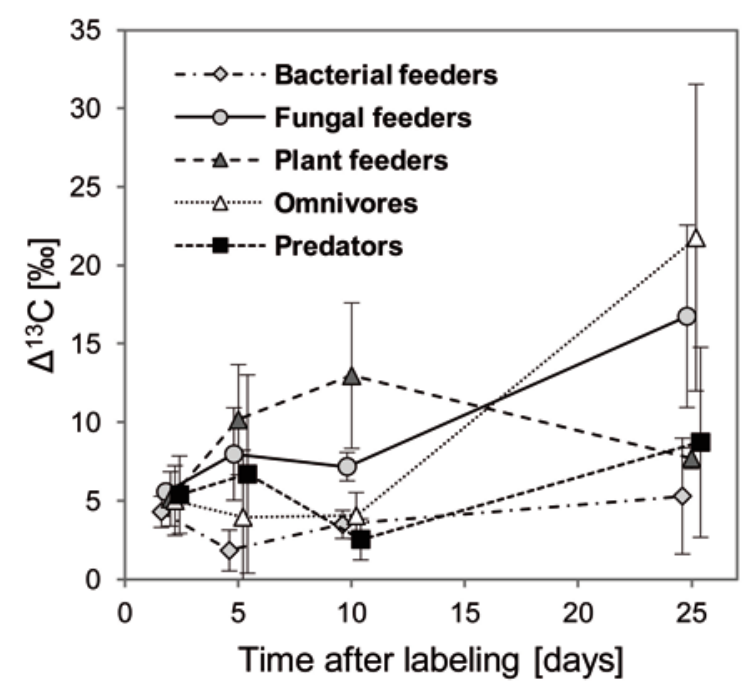

Figure 3: Changes in the incorporation of ${ }^{13} \mathrm{C}$ into nematodes during 25 days after labeling (means \pm SEM, $n=4$ ). 


\section{Incorporation of ${ }^{13} \mathrm{C}$ and ${ }^{15} \mathrm{~N}$ into soil arthropods}

Based on unlabeled stable isotope signatures from the control samples, we constructed the food web of the present arable field (Fig. S1), and separated soil arthropod taxa into trophic groups (see 2.4), with low trophic level macrofauna species including six taxa with average natural abundance $\delta^{15} \mathrm{~N}$ of $3.3 \pm 0.6 \%$, high trophic level macrofauna species including six taxa with average $\delta^{15} \mathrm{~N}$ of $9.1 \pm 1.4 \%$, low trophic level mesofauna species including three taxa with $\delta^{15} \mathrm{~N}$ of $6.0 \pm 1.0 \%$, and high trophic level mesofauna species including ten taxa with average $\delta^{15} \mathrm{~N}$ of $10.1 \pm 1.2 \%$.

Each of the species studied incorporated root-derived ${ }^{13} \mathrm{C}$ and fertilizer-derived ${ }^{15} \mathrm{~N}$, but the enrichment differed between taxa, sampling date and element (Tables S3 and S4). The incorporation of ${ }^{13} \mathrm{C}$ into meso- and macrofauna averaged $12.3 \pm 1.4 \%$ across sampling dates and increased during the experiment $\left(F_{3,143}=3.66, p=0.014\right)$, with the enrichment being significantly higher at $d 25$ than at $d 2$, d5 and $d 10$. Generally, ${ }^{13} C$ incorporation did not differ between trophic groups $\left(F_{3,72}=0.66, p=0.587\right)$, but increased with time in high trophic level taxa, whereas it remained more constant in low trophic level taxa (sampling date $\times$ meso-/macrofauna interaction; $F_{9,134}=3.19, p=0.006$; Fig. 4).

In general, ${ }^{15} \mathrm{~N}$ incorporation increased during the experiment across trophic groups and averaged $36.9 \pm 6.7 \%$ at day 2 and $158.6 \pm 51.1 \%$ ot day $25\left(F_{3,143}=11.42, p<0.0001\right)$. The increase was similar in each of the trophic groups (sampling date $\times$ meso/macrofauna interaction; $F_{9,134}=1.33, p=0.229$ ), while average incorporation was higher in low trophic level mesofauna than low trophic level macrofauna, with high trophic level macrofauna and mesofauna displaying intermediate ${ }^{15} \mathrm{~N}$ enrichment $\left(F_{3,72}=4.52, p=0.006\right.$; Fig. 5).

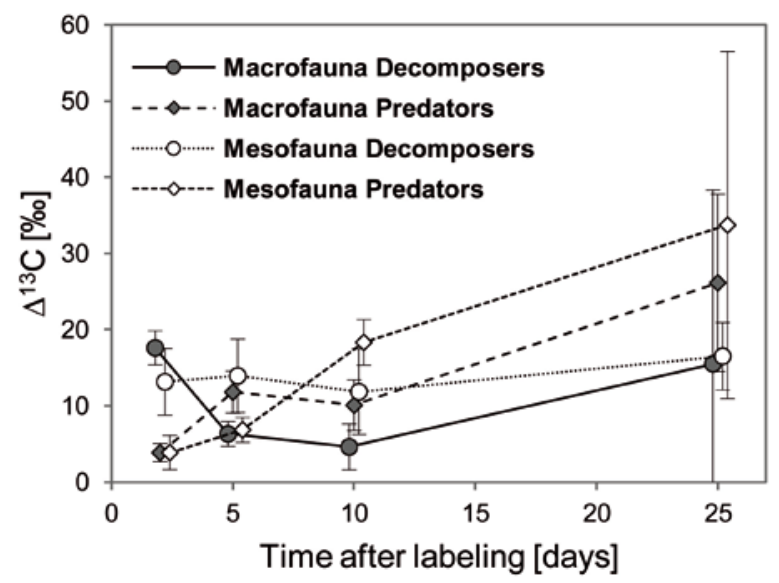

Figure 4: Changes in the incorporation of ${ }^{13} \mathrm{C}$ into meso- and macrofauna of low and high trophic level during 25 days after labeling (means \pm SEM, number of replicates varied between $n=3$ for low trophic level macrofauna at day 25 to $\mathrm{n}=18$ for high trophic level macrofauna at day 5). 


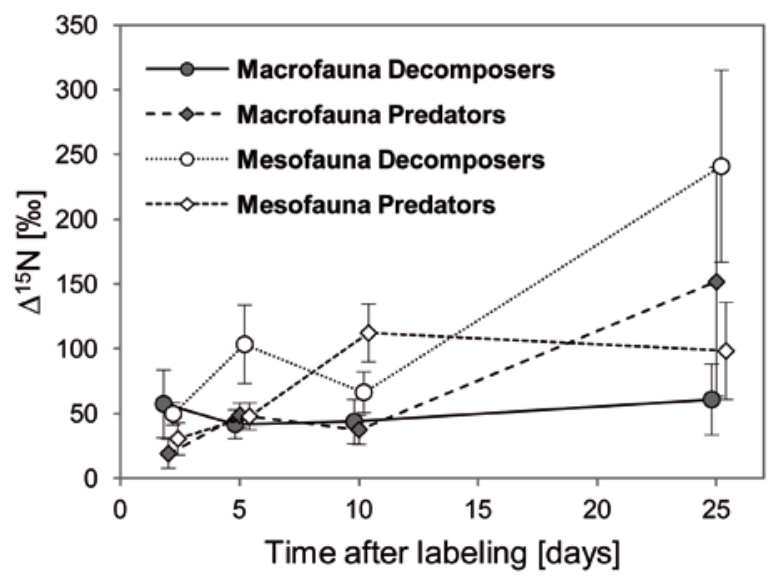

Figure 5: Changes in the incorporation of ${ }^{15} \mathrm{~N}$ into meso- and macrofauna of low and high trophic level during 25 days after labeling (means \pm SEM, number of replicates varied between $n=3$ for low trophic level macrofauna at day 25 to $n=18$ for high trophic level macrofauna at day 5 ).

\section{Discussion}

\section{Incorporation of ${ }^{13} \mathrm{C}$ and ${ }^{15} \mathrm{~N}$ into the soil food web}

Root-derived $C$ rapidly propagated through the soil food web from basal trophic levels including bacteria and fungi to higher trophic levels including nematodes and arthropods, confirming our first hypothesis. Since previous studies performed in microcosms (Ruf et al., 2006) and forest ecosystems (Pollierer et al., 2007) yielded similar results, we conclude that root-derived $C$ is an important resource for the soil food web across ecosystems (Balasooriya et al., 2014; Strickland et al., 2012).

Notably, incorporation of root-derived C into fungi strongly exceeded that into bacteria, particularly at day 2 after labeling, followed by a rapid loss of ${ }^{13} \mathrm{C}$ until day 25 . This is in contrast to the general assumption of a slower fungal metabolism and therefore higher C storage in soil fungi than bacteria (Six et al., 2006; Strickland and Rousk, 2010), but reflects the high activity of soil fungi as compared to bacteria in the present arable field (Pausch et al., 2015). The low fungi-to-bacteria ratio at the study site (Scharroba et al., 2012) and other arable fields (Esperschütz et al., 2007, Ngosong et al., 2010), and therefore higher $\mathrm{C}$ pool size of bacteria may have resulted in dilution of the label in bacteria. However, Pausch et al. (2015) showed the net incorporation of ${ }^{13} \mathrm{C}$ into fungi to exceed that into bacteria, despite the smaller $\mathrm{C}$ pool size of the former. Further, decreasing ${ }^{13} \mathrm{C}$ signatures in fungal PLFAs suggests that recently assimilated plant $\mathrm{C}$ 
quickly passes through the saprotrophic fungal community and leaves the soil system via respiration (Pausch et al., 2015), pointing to a low microbial growth efficiency of saprotrophic fungi in arable fields.

The occurrence of mycorrhizal fungi was very low at our field site as assigned by molecular analyses (J. Moll, pers. comm.), indicating that mainly saprotrophic fungi accounted for the high ${ }^{13} \mathrm{C}$ enrichment. Saprotrophic fungi are assumed to predominantly rely on aboveground litter resources (Ruess and Ferris, 2004), but our results suggest that they took over the role of arbuscular mycorrhiza fungi that are considered to be the major conduit in transfer of plant $C$ into arable soils (Drigo et al., 2010). Our results support earlier findings by Kramer et al. (2012) who also found high contribution of saprotrophic as compared to mycorrhizal fungi to fungal biomass at our field site. Furthermore, the results are in line with recent studies in arable and grassland systems stressing the key role of saprotrophic fungi in channeling $C$ to higher trophic levels (Lemanski and Scheu, 2014a, b; Tavi et al., 2013). Fast incorporation of ${ }^{13} \mathrm{C}$ into high trophic level taxa, i.e. fungal feeders and predators, and high incorporation of rootderived ${ }^{13} \mathrm{C}$ into saprotrophic fungi in the present study underpin the importance of the fungal energy channel for soil animal food webs and suggest that $C$ flux via saprotrophic fungi is more important than previously assumed (Moore et al., 2005; Ngosong et al., 2009).

Fertilizer-derived $\mathrm{N}$ was incorporated into each of the taxa of meso- and macrofauna proving that mineral nutrients in soil are channeled rapidly into the soil food web. The combined incorporation of root-derived ${ }^{13} \mathrm{C}$ and fertilizer-derived ${ }^{15} \mathrm{~N}$ into soil meso- and macrofauna suggest that saprotrophic microorganisms function as major control point in channeling $\mathrm{N}$ from inorganic resources and $\mathrm{C}$ from root-derived resources to higher trophic levels. Both types of resources are available for meso- and macrofauna via the fungal energy channel, since fungal hyphae are the main food resource of many species (Scheu and Falca, 2000), and earlier studies suggest that soil arthropods readily incorporate fungal $\mathrm{N}$ as well as C (Eissfeller et al., 2013). 


\section{Temporal dynamics}

Different incorporation patterns of ${ }^{13} \mathrm{C}$ and ${ }^{15} \mathrm{~N}$ into the soil food web indicate that the fluxes of root-derived $C$ and inorganic nutrients varied markedly. This contrasts our expectations and suggests that root derived resources function as short term pulse in fueling soil food webs, whereas fertilizer-derived $\mathrm{N}$ is incorporated more continuously.

In plant tissue and rhizosphere soil microorganisms, the enrichment in ${ }^{13} \mathrm{C}$ was highest at day 2 , while ${ }^{13} \mathrm{C}$ incorporation into nematodes and meso- and macrofauna increased with time or remained constant. Thus, root $\mathrm{C}$ rapidly enters basal trophic levels, while incorporation into higher trophic levels is delayed, confirming our second hypothesis. This is in line with studies that found plant derived $C$ entering the microbial soil food web within a few days (Leake et al. 2006; Pausch et al. 2013). However, at higher trophic levels, i.e. within low trophic level meso- and macrofauna, ${ }^{13} \mathrm{C}$ incorporation did not increase rapidly, but was constant throughout the sampling dates, while it increased with time in high trophic level taxa.

Whereas the constant ${ }^{13} \mathrm{C}$ signatures of low trophic level taxa suggest that they quickly incorporated root $\mathrm{C}$, the low amount of incorporated ${ }^{13} \mathrm{C}$ points to unlabeled litter residues as an additional important resource. Consequently, increasing incorporation of ${ }^{13} \mathrm{C}$ into high trophic level taxa in time can most likely be explained by relying on nematode prey rather than arthropod decomposers. Supporting this assumption, Collembola and Gamasida made up the majority of fungal feeding and predatory species in the present study, and have both been found to intensively feed on nematodes (Heidemann et al. 2014; Read et al., 2006). Similar to high trophic level meso- and macrofauna, ${ }^{13} \mathrm{C}$ in fungivorous nematodes generally increased with time, pointing to the possibility that high trophic level meso- and macrofauna included omnivorous species that rely on soil fungi as well as animal prey. The role of nematodes as prey for decomposer soil invertebrates has been discussed recently with molecular gut content analyses indicating high feeding rates (Heidemann et al., 2014; Read et al., 2006), but the extent to which decomposers rely on nematodes as food remains controversial (Kudrin et al., 2015). Due to the lack of nematode ${ }^{15} \mathrm{~N}$ data we cannot prove their role as prey for higher trophic levels in the studied soil food web, but high ${ }^{15} \mathrm{~N}$ signatures in many mesofauna taxa indicate feeding on other soil animals, most likely nematodes 
In contrast to root-derived ${ }^{13} \mathrm{C}$, incorporation of fertilizer-derived ${ }^{15} \mathrm{~N}$ increased with time in plant tissue and soil arthropods. This suggests that inorganic nutrients are incorporated increasingly into soil microorganisms, presumably fungi, and channeled in a proportional way into higher trophic levels of the soil food web (Eissfeller et al., 2013). Notably, ${ }^{15} \mathrm{~N}$ changes with time did not significantly differ between trophic groups of meso- and macrofauna, indicating that $\mathrm{N}$ flows in a homogeneous way through the soil food web. Uptake of $\mathrm{N}$ by soil arthropods mainly occurs via microorganisms (Caner et al., 2004). In the arable field studied saprotrophic fungi showed much higher activity than bacteria (Pausch et al., 2015), suggesting that the former incorporated ${ }^{15} \mathrm{~N}$ more rapidly. Preferential feeding on fungi as compared to bacteria in most soil arthropods further points to a central position of saprotrophic fungi in channeling $\mathrm{N}$ to higher trophic levels of soil meso- and macrofauna, supporting earlier findings for forest soil food webs (Eissfeller et al., 2013).

\section{Extent of ${ }^{13} \mathrm{C}$ enrichment in different trophic levels}

The incorporation of root-derived ${ }^{13} \mathrm{C}$ decreased markedly along the food chain. Little incorporation into nematodes and meso- and macrofauna suggests that rootderived $\mathrm{C}$ is locked up in rhizosphere microorganisms, quickly leaves the soil system via respiration (Pausch and Kuzyakov, 2012, Pausch et al. 2013), and does not reach higher trophic levels. Nevertheless, all food web compartments incorporated ${ }^{13} \mathrm{C}$ rapidly after labeling, underlining the importance of root-derived $C$ as major $C$ source in arable soils.

Higher incorporation of root-derived $\mathrm{C}$ into fungivorous and omnivorous nematodes as compared to other nematode trophic groups suggests that they allocated plant $C$ directly from saprotrophic fungi, as those very efficiently captured plant C (Pausch et al., 2015; Riederer et al., 2015). Obviously, fungal feeders achieved the ${ }^{13} \mathrm{C}$ enrichment by their direct trophic linkage to fungi, while the high incorporation of ${ }^{13} \mathrm{C}$ into omnivores suggests a considerable proportion of fungal tissue as diet, besides feeding on other (labeled) nematodes.

Later in the experiment, soil animal predators incorporated higher amounts of ${ }^{13} \mathrm{C}$ than decomposers, contradicting our third hypothesis. Nematodes form an important part of the diet of soil fauna predators (Heidemann et al., 2014; Koehler, 1997; Read et 
al., 2006), but the the similar incorporation patterns of soil fauna predators and fungivorous nematodes suggest direct feeding on soil fungi as the main ${ }^{13} \mathrm{C}$ source for most species grouped as high trophic level taxa, and nematodes as supplementary diet, resulting in omnivory as the main feeding strategy. Nematode feeding likely diluted the incorporation of ${ }^{13} \mathrm{C}$ into high trophic level meso- and macrofauna due to the high contribution of less labeled bacterial feeders to the nematode community at the investigated field site (Scharroba et al., 2012). However, nematodes were extracted from bulk soil and incorporation of root-derived ${ }^{13} \mathrm{C}$ into rhizosphere nematodes, in particular bacterial and plant feeders, presumably was underestimated.

The efficiency of plants in incorporation of $\mathrm{CO}_{2}$ and releasing $\mathrm{C}$ via roots may have affected the incorporation of labeled $\mathrm{C}$ into the soil food web, as indicated by the high variability of ${ }^{13} \mathrm{C}$ incorporation between replicates, i.e. labeling chambers. Nonetheless, our results suggest that the incorporation of root-derived $\mathrm{C}$ and fertilizer-derived $\mathrm{N}$ decreases at higher trophic levels, as also suggested by Pausch et al. (2015).

\section{Conclusion}

The dual ${ }^{13} \mathrm{C}$ and ${ }^{15} \mathrm{~N}$ labeling approach allowed following the flux of energy and nutrients through an arable soil food web. The root-derived resources are of essential importance for arable soil food webs, and root-derived $\mathrm{C}$ is channeled to higher trophic levels concurrently with fertilizer-derived N, predominantly via saprotrophic fungi. Increasing amounts of root-derived $\mathrm{C}$ and fertilizer-derived $\mathrm{N}$ with time suggest that the bottom up transfer of resources is shaped by high connectivity within the food web, i.e. high degrees of omnivory in higher trophic levels. Rapid incorporation of root-derived $\mathrm{C}$ into rhizosphere microorganisms and lower incorporation into micro-, meso- and macrofauna suggest that in arable systems the majority of root-derived $C$ remains locked up at the base of the soil food web. 


\section{Acknowledgements}

We thank Reinhard Langel at the Kompetenzzentrum Stabile Isotope (KOSI), University of Göttingen, for stable isotope measurements. Thanks to Stephanie Wolf for her work on the identification of taxa, to Bernhard Klarner and Verena Eißfeller for help in the identification of Gamasida and Oribatida, respectively, and to David Ott for advice in using R. Financial support was provided by the German Research Foundation (DFG) within the Research Unit "Carbon flow in belowground food webs assessed by isotope tracers" (FOR 918).

\section{References}

Bahri, H., Dignac, M.-F., Rumpel, C., Rasse, D.P., Chenu, C., Mariotti, A., 2006. Lignin turnover kinetics in an agricultural soil is monomer specific. Soil Biology \& Biochemistry 38, 1977-1988.

Balasooriya, W.K., Denef, K., Huygens, D., Boeckx, P., 2014. Translocation and turnover of rhizodeposit carbon within soil microbial communities of an extensive grassland ecosystem. Plant and Soil 376, 61-73.

Berg, M.P., Stoffer, M., van den Heuvel, H.H., 2004. Feeding guilds in Collembola based on digestive enzymes. Pedobiologia 48, 589-601.

Bradford, M.A., Strickland, M.S., DeVore, J.L., Maerz, J.C., 2012. Root carbon flow from an invasive plant to belowground foodwebs. Plant and Soil 359, 233-244.

Caner, L., Zeller, B., Dambrine, É., Ponge, J.-F., Chauvat, M., Llanque, C., 2004. Origin of the nitrogen assimilated by soil fauna living in decomposing beech litter. Soil Biology \& Biochemistry $36,1861-1872$.

Crotty, F. V., Blackshaw, R.P., Murray, P.J., 2011. Tracking the flow of bacterially derived ${ }^{13} \mathrm{C}$ and ${ }^{15} \mathrm{~N}$ through soil faunal feeding channels. Rapid Communications in Mass Spectrometry 25, 1503-1513.

De Deyn, G.B., Cornelissen, J.H.C., Bardgett, R.D., 2008. Plant functional traits and soil carbon sequestration in contrasting biomes. Ecology Letters 11, 516-531. 
Drigo, B., Pijl, A.S., Duyts, H., Kielak, A.M., Gamper, H.A., Houtekamer, M.J., 2010. Shifting carbon flow from roots into associated microbial communities in response to elevated atmospheric $\mathrm{CO}_{2}$. PNAS 107, 10938-10942.

Eissfeller, V., Beyer, F., Valtanen, K., Hertel, D., Maraun, M., Polle, A., Scheu, S., 2013. Incorporation of plant carbon and microbial nitrogen into the rhizosphere food web of beech and ash. Soil Biology \& Biochemistry 62, 76-81.

Esperschütz, J., Gattinger, A., Mäder, P., Schloter, M., Fließbach, A., 2007. Response of soil microbial biomass and community structures to conventional and organic farming systems under identical crop rotations. FEMS Microbiology Ecology 61, 26-37.

Foley, J.A., Defries, R., Asner, G.P., Barford, C., Bonan, G.B., Carpenter, S.R., Chapin, F.S., Coe, M.T., Daily, G.C., Gibbs, H.K., Helkowski, J.H., Holloway, T., Howard, E.A., Kucharik, C.J., Monfreda, C., Patz, J.A., Prentice, I.C., Ramankutty, N., Snyder, P.K., 2005. Global consequences of land use. Science 309, 570-574.

Kucharik, C.J., Monfreda, C., Patz, J.A., Prentice, I.C., Ramankutty, N., Snyder, P.K., 2005. Global consequences of land use. Science 309, 570-574.

Fox, J., 2003. Effect displays in R for generalised linear models. Journal of Statistical Software 8, 1-27.

Frostegard, A., Tunlid, A., Baath, E., 1991. Microbial biomass measured as total lipid phosphate in soils of different organic content. Journal of Microbiological Methods $14,151-163$.

Gaudinski, J.B., Trumbore, S.E., Davidson, E.A., Zheng, S., 2000. Soil carbon cycling in a temperate forest: Radiocarbon-based estimates of residence times, sequestration rates and partitioning of fluxes. Biogeochemistry 51, 33-69.

Gilbert, K.J., Fahey, T.J., Maerz, J.C., Sherman, R.E., Bohlen, P.J., Dombroskie, J.J., Groffman, P.M., Yavitt, J.B., 2014. Exploring carbon flow through the root channel in a temperate forest soil food web. Soil Biology \& Biochemistry 76, 45-52.

Heidemann, K., Hennies, A., Schakowske, J., Blumenberg, L., Ruess, L., Scheu, S., Maraun, M., 2014. Free-living nematodes as prey for higher trophic levels of forest soil food webs. Oikos 123, 1199-1211.

Högberg, M.N., Briones, M.J.I., Keel, S.G., Metcalfe, D.B., Campbell, C.D., Midwood, A.J., Thornton, B., Hurry, V., Linder, S., Näsholm, T., Högberg, P., 2010. Quantification of 
effects of season and nitrogen supply on tree below-ground carbon transfer to ectomycorrhizal fungi and other soil organisms in a boreal pine forest. New Phytologist 187, 485-93.

Hopkin, S.P., 2007. A Key to the Collembola (Springtails) of Britain and Ireland, 1st ed. Field Studies Council.

Hothorn, T., Bretz, F., Westfall, P., 2008. Simultaneous inference in general parametric models. Biometrical Journal 50, 346-363.

Karg, W., 1993. Die Tierwelt Deutschlands 59 - Raubmilben, 2nd ed. Gustav Fischer Verlag, Jena-Stuttgart-New York.

Kempson, D., Lloyd, M., Ghelardi, M., 1963. A new extractor for woodland litter. Pedobiologia 3, 1-21.

Klarner, B., Maraun, M., Scheu, S., 2013. Trophic diversity and niche partitioning in a species rich predator guild - Natural variations in stable isotope ratios $\left({ }^{13} \mathrm{C} /{ }^{12} \mathrm{C}\right.$, ${ }^{15} \mathrm{~N} /{ }^{14} \mathrm{~N}$ ) of mesostigmatid mites (Acari, Mesostigmata) from Central European beech forests. Soil Biology \& Biochemistry 57, 327-333.

Koehler, H.H., 1997. Mesostigmata (Gamasina, Uropodina), efficient predators in agroecosystems. Agriculture, Ecosystems \& Environment 62, 105-117.

Kramer, J.K.G., Hernandez, M., Cruz-Hernandez, C., Kraft, J., Dugan, M.E.R., 2008. Combining results of two GC separations partly achieves determination of all cis and trans 16:1, 18:1, 18:2 and 18:3 except CLA isomers of milk fat as demonstrated using Ag-ion SPE fractionation. Lipids 43, 259-73.

Kramer, S., Marhan, S., Ruess, L., Armbruster, W., Butenschoen, O., Haslwimmer, H., Kuzyakov, Y., Pausch, J., Scheunemann, N., Schoene, J., Schmalwasser, A., Totsche, K.U., Walker, F., Scheu, S., Kandeler, E., 2012. Carbon flow into microbial and fungal biomass as a basis for the belowground food web of agroecosystems. Pedobiologia 55, 111-119.

Kramer, S., Marhan, S., Haslwimmer, H., Ruess, L., Kandeler, E., 2013. Temporal variation in surface and subsoil abundance and function of the soil microbial community in an arable soil. Soil Biology \& Biochemistry $61,76-85$. 
Kudrin, A.A., Tsurikov, S.M., Tiunov, A.V., 2015. Trophic position of microbivorous and predatory soil nematodes in a boreal forest as indicated by stable isotope analysis. Soil Biology \& Biochemistry 86, 193-200.

Lal, R., 2004a. Soil carbon sequestration impacts on global climate change and food security. Science 304, 1623-1627.

Lal, R., 2004b. Soil carbon sequestration to mitigate climate change. Geoderma 123, 1-22. Langel, R., Dyckmans, J., 2014. Combined ${ }^{13} \mathrm{C}$ and ${ }^{15} \mathrm{~N}$ isotope analysis on small samples using a near-conventional elemental analyzer/isotope ratio mass spectrometer setup. Rapid Communications in Mass Spectrometry 28, 1019-1022.

Leake, J.R., Ostle, N.J., Rangel-Castro, J.I., Johnson, D., 2006. Carbon fluxes from plants through soil organisms determined by field ${ }^{13} \mathrm{CO}_{2}$ pulse-labelling in an upland grassland. Applied Soil Ecology 33, 152-175.

Lemanski, K., Scheu, S., 2014a. Incorporation of ${ }^{13} \mathrm{C}$ labelled glucose into soil microorganisms of grassland: Effects of fertilizer addition and plant functional group composition. Soil Biology \& Biochemistry 69, 38-45.

Lemanski, K., Scheu, S., 2014b. Fertilizer addition lessens the flux of microbial carbon to higher trophic levels in soil food webs of grassland. Oecologia 176, 487-496.

Loya, W.M., Johnson, L.C., Kling, G.W., King, J.Y., Reeburgh, W.S., Nadelhoffer, K.J., 2002. Pulse-labeling studies of carbon cycling in arctic tundra ecosystems: Contribution of photosynthates to soil organic matter. Global Biogeochemical Cycles 16, 1-8.

Moll, J., Goldmann, K., Kramer, S., Hempel, S., Kandeler, E., Marhan, S., Ruess, L., Krüger, D., Buscot, F., 2015. Resource type and availability regulate fungal communities along arable soil profiles. Microbial Ecology 70, 390-399.

Moore, J.C., Berlow, E.L., Coleman, D.C., De Ruiter, P.C., Dong, Q., Hastings, A., Johnson, N.C., McCann, K.S., Melville, K., Morin, P.J., Nadelhoffer, K.J., Rosemond, A.D., Post, D.M., Sabo, J.L., Scow, K.M., Vanni, M.J., Wall, D.H., 2004. Detritus, trophic dynamics and biodiversity. Ecology Letters 7, 584-600.

Moore, J.C., McCann, K.S., De Ruiter, P.C., 2005. Modeling trophic pathways, nutrient cycling, and dynamic stability in soils. Pedobiologia 49, 499-510. 
Ngosong, C., Raupp, J., Scheu, S., Ruess, L., 2009. Low importance for a fungal based food web in arable soils under mineral and organic fertilization indicated by Collembola grazers. Soil Biology \& Biochemistry 41, 2308-2317.

Ngosong, C., Jarosch, M., Raupp, J., Neumann, E., Ruess, L., 2010. The impact of farming practice on soil microorganisms and arbuscular mycorrhizal fungi: Crop type versus long-term mineral and organic fertilization. Appl Soil Ecol 46, 134-142.

Pausch, J., Kuzyakov, Y., 2012. Soil organic carbon decomposition from recently added and older sources estimated by $\delta^{13} \mathrm{C}$ values of $\mathrm{CO}_{2}$ and organic matter. Soil Biology \& Biochemistry 55, 40-47.

Pausch, J., Tian, J., Riederer, M., Kuzyakov, Y., 2013. Estimation of rhizodeposition at field scale: Upscaling of a ${ }^{14} \mathrm{C}$ labeling study. Plant and Soil 364, 273-285.

Pausch, J., Kramer, S., Scharroba, A., Scheunemann, N., Butenschoen, O., Kandeler, E., Marhan, S., Riederer, M., Scheu, S., Kuzyakov, Y., Ruess, L.; 2015. Small but active pool size does not matter for carbon incorporation in belowground food webs. Functional Ecology, available online.

Pinheiro, J., Bates, D., DebRoy, S., Sarkar, D., R.D.C. Team, 2013. NLME: Linear and nonlinear mixed effects models. $R$ package version 3.1-111.

Pollierer, M.M., Dyckmans, J., Scheu, S., Haubert, D., 2012. Carbon flux through fungi and bacteria into the forest soil animal food web as indicated by compound-specific ${ }^{13} \mathrm{C}$ fatty acid analysis. Functional Ecology 26, 978-990.

Pollierer, M.M., Langel, R., Körner, C., Maraun, M., Scheu, S., 2007. The underestimated importance of belowground carbon input for forest soil animal food webs. Ecology Letters 10, 729-736.

R Core Team, 2013. R: A language and environment for statistical computing. $R$ Foundation for Statistical Computing.

Raich, J.W., Schlesinger, W.H., 1992. The global carbon dioxide flux in soil respiration and its relationship to vegetation and climate. Tellus 44B, 81-99.

Read, D.S., Sheppard, S.K., Bruford, M.W., Glen, D.M., Symondson, W.O.C., 2006. Molecular detection of predation by soil micro-arthropods on nematodes. Molecular Ecology 15, 1963-1972. 
Reineking, A., Langel, R., Schikowski, J., $1993 .{ }^{15} \mathrm{~N},{ }^{13} \mathrm{C}$-on-line measurements with an elemental analyser (Carlo Erba, NA 1500), a modified trapping box and a gas isotope mass spectrometer (FINNIGAN, MAT 251). Isotopenpraxis Environmental Health Studies 29, 169-174.

Riederer, M., Pausch, J., Kuzyakov, Y., Foken, T., 2015. Partitioning NEE for absolute C input into various ecosystem pools by combining results from eddy-covariance, atmospheric flux partitioning and ${ }^{13} \mathrm{CO}_{2}$ pulse labeling. Plant and Soil, Plant and Soil $390,61-76$.

Ruess, L., 1995. Studies On the nematode fauna of an acid forest soil: Spatial distribution and extraction. Nematologica 41, 229-239.

Ruess, L., Chamberlain, P.M., 2010. The fat that matters: Soil food web analysis using fatty acids and their carbon stable isotope signature. Soil Biology \& Biochemistry 42, 1898-1910.

Ruess, L., Ferris, H., 2004. Decomposition pathways and successional changes. Nematology Monographs \& Perspectives 2, 547-556.

Ruf, A., Kuzyakov, Y., Lopatovskaya, O., 2006. Carbon fluxes in soil food webs of increasing complexity revealed by ${ }^{14} \mathrm{C}$ labelling and ${ }^{13} \mathrm{C}$ natural abundance. Soil Biology \& Biochemistry 38, 2390-2400.

Schaefer, M., 2010. Brohmer - Fauna von Deutschland, 23rd ed. Quelle \& Meyer Verlag, Wiebelsheim.

Scharroba, A., Dibbern, D., Hünninghaus, M., Kramer, S., Moll, J., Butenschoen, O., Bonkowski, M., Buscot, F., Kandeler, E., Koller, R., Krüger, D., Lueders, T., Scheu, S., Ruess, L., 2012. Effects of resource availability and quality on the structure of the micro-food web of an arable soil across depth. Soil Biology \& Biochemistry 50, 1-11.

Scheu, S., Falca, M., 2000. The soil food web of two beech forests (Fagus sylvatica) of contrasting humus type: stable isotope analysis of a macro- and a mesofaunadominated community. Oecologia 123, 285-296.

Schneider, K., Migge-Kleian, S., Norton, R.A., Scheu, S., Langel, R., Reineking, A., Maraun, M., 2004. Trophic niche differentiation in soil microarthropods (Oribatida, Acari): Evidence from stable isotope ratios $\left({ }^{15} \mathrm{~N} /{ }^{14} \mathrm{~N}\right)$. Soil Biology \& Biochemistry 36, 17691774. 
Schneider, T., Keiblinger, K.M., Schmid, E., Sterflinger-Gleixner, K., Ellersdorfer, G., Roschitzki, B., Richter, A., Eberl, L., Zechmeister-Boltenstern, S., Riedel, K., 2012. Who is who in litter decomposition? Metaproteomics reveals major microbial players and their biogeochemical functions. The ISME Journal 6, 1749-1762.

Six, J., Frey, S.D., Thiet, R.K., Batten, K.M., 2006. Bacterial and fungal contributions to carbon sequestration in agroecosystems. Soil Science Society of America Journal 70, 555-569.

Strickland, M.S., Rousk, J., 2010. Considering fungal:bacterial dominance in soils Methods, controls, and ecosystem implications. Soil Biology \& Biochemistry 42, 1385-1395.

Strickland, M.S., Wickings, K., Bradford, M.A., 2012. The fate of glucose, a low molecular weight compound of root exudates, in the belowground foodweb of forests and pastures. Soil Biology \& Biochemistry 49, 23-29.

Tavi, N.M., Martikainen, P.J., Lokko, K., Kontro, M., Wild, B., Richter, A., Biasi, C., 2013. Linking microbial community structure and allocation of plant-derived carbon in an organic agricultural soil using ${ }^{13} \mathrm{CO}_{2}$ pulse-chase labelling combined with ${ }^{13} \mathrm{C}$-PLFA profiling. Soil Biology \& Biochemistry 58, 207-215.

Tilman, D., Balzer, C., Hill, J., Befort, B.L., 2011. Global food demand and the sustainable intensification of agriculture. Proceedings of the National Academy of Sciences of the United States of America 108, 20260-20264.

Vanderklift, M.A., Ponsard, S., 2003. Sources of variation in consumer-diet delta ${ }^{15} \mathrm{~N}$ enrichment: A meta-analysis. Oecologia 136, 169-82.

Weigmann, G., 2006. Die Tierwelt Deutschlands Teil 76 - Hornmilben (Oribatida), 1st ed. Goecke \& Evers, Keltern.

Yeates, G.W., Bongers, T., De Goede, R.G., Freckman, D.W., Georgieva, S.S., 1993. Feeding habits in soil nematode families and genera-an outline for soil ecologists.Journal of Nematology 25, 315-331. 


\section{Supporting information}

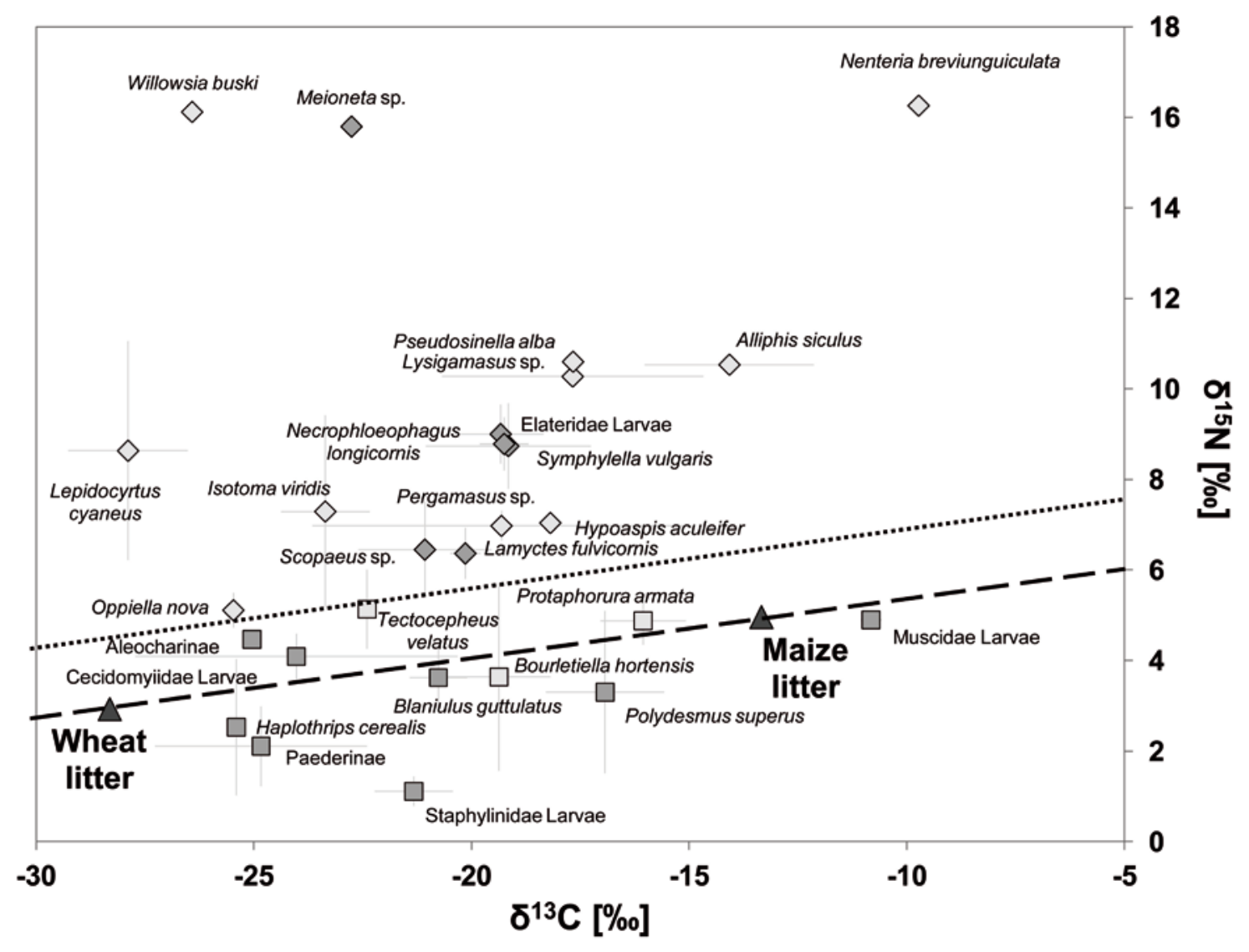

Figure S1: Natural variations in stable isotope ratios in wheat and maize litter and in soil animal species; dark grey squares = low trophic level macrofauna, dark grey diamonds = high trophic level macrofauna, light grey squares = low trophic level mesofauna, light grey diamonds = high trophic level mesofauna. Black triangles mark stable isotope signatures of maize and wheat shoots. Error bars show standard error (SEM). Dashed line: baseline; dotted line: threshold between low (below) and high trophic level taxa (above).

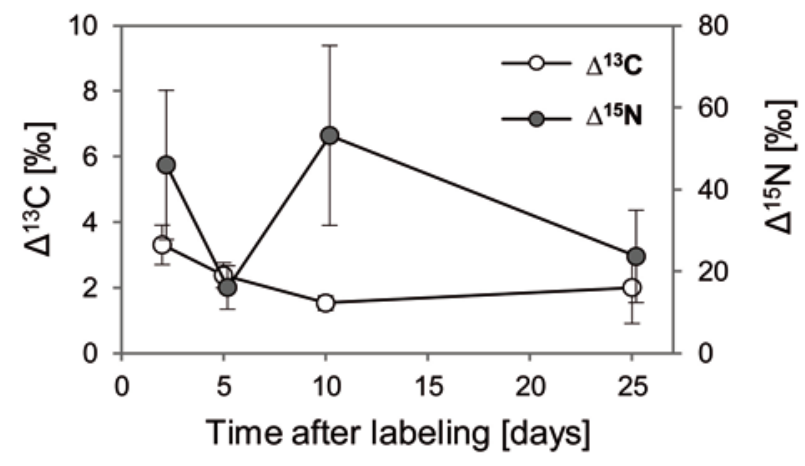

Figure S2: Changes in the incorporation of ${ }^{13} \mathrm{C}$ (white circles, primary $\mathrm{y}$-axis) and ${ }^{15} \mathrm{~N}$ (black circles, secondary $\mathrm{y}$-axis) into bulk soil during 25 days after labeling (means $\pm S E M, n=4$ ). 
Table S3: Incorporation of ${ }^{13} \mathrm{C}$ into soil animal species after labeling $\left(\Delta^{13} \mathrm{C}\right) .2 \mathrm{~d}=2$ days after labeling, $5 \mathrm{~d}=5$ days, $10 \mathrm{~d}=$ 10 days, $25 d=25$ days; SEM = standard error of the mean; values lacking parentheses represent single measurements.

\begin{tabular}{|c|c|c|c|c|c|c|}
\hline \multirow{2}{*}{\multicolumn{2}{|c|}{ Species }} & \multirow{2}{*}{ Trophic group } & \multicolumn{4}{|c|}{$\Delta^{13} \mathrm{C}$ ( \pm SEM) } \\
\hline & & & $2 d$ & $5 d$ & $10 \mathrm{~d}$ & $25 d$ \\
\hline Collembola & $\begin{array}{c}\text { Bourletiella } \\
\text { hortensis }\end{array}$ & $\begin{array}{c}\text { Low trophic level } \\
\text { mesofauna }\end{array}$ & $\begin{array}{c}6.69 \\
( \pm 2.77)\end{array}$ & $\begin{array}{c}5.95 \\
( \pm 2.58)\end{array}$ & $\begin{array}{c}0.00 \\
( \pm 1.42)\end{array}$ & 3.97 \\
\hline Collembola & Isotoma viridis & $\begin{array}{l}\text { High trophic level } \\
\text { mesofauna }\end{array}$ & $\begin{array}{c}2.33 \\
( \pm 1.69)\end{array}$ & $\begin{array}{c}10.85 \\
( \pm 4.00)\end{array}$ & 5.11 & $\begin{array}{r}11.53 \\
( \pm 1.63)\end{array}$ \\
\hline Collembola & $\begin{array}{l}\text { Lepidocyrtus } \\
\text { cyaneus }\end{array}$ & $\begin{array}{l}\text { High trophic level } \\
\text { mesofauna }\end{array}$ & $\begin{array}{c}6.94 \\
( \pm 1.39)\end{array}$ & $\begin{array}{c}7.80 \\
( \pm 5.17)\end{array}$ & & 23.28 \\
\hline Collembola & $\begin{array}{c}\text { Protaphorura } \\
\text { armata }\end{array}$ & $\begin{array}{l}\text { Low trophic level } \\
\text { mesofauna }\end{array}$ & $\begin{array}{c}25.80 \\
( \pm 0.91)\end{array}$ & $\begin{array}{c}33.50 \\
( \pm 15.01)\end{array}$ & $\begin{array}{c}40.23 \\
( \pm 20.20)\end{array}$ & $\begin{array}{r}33.23 \\
( \pm 2.61)\end{array}$ \\
\hline Collembola & $\begin{array}{c}\text { Pseudosinella } \\
\text { alba }\end{array}$ & $\begin{array}{l}\text { High trophic level } \\
\text { mesofauna }\end{array}$ & 2.27 & $\begin{array}{c}11.89 \\
( \pm 4.43)\end{array}$ & $\begin{array}{c}29.39 \\
( \pm 8.95)\end{array}$ & \\
\hline Collembola & Willowsia buski & $\begin{array}{l}\text { High trophic level } \\
\text { mesofauna }\end{array}$ & & $\begin{array}{c}3.12 \\
( \pm 0.76)\end{array}$ & 9.82 & \\
\hline Oribatida & Oppiella nova & $\begin{array}{l}\text { High trophic level } \\
\text { mesofauna }\end{array}$ & 29.91 & 20.17 & $\begin{array}{c}21.77 \\
( \pm 4.73)\end{array}$ & \\
\hline Oribatida & $\begin{array}{c}\text { Tectocepheus } \\
\text { velatus }\end{array}$ & $\begin{array}{c}\text { Low trophic level } \\
\text { mesofauna }\end{array}$ & $\begin{array}{c}1.61 \\
( \pm 0.40)\end{array}$ & $\begin{array}{c}4.35 \\
( \pm 0.70)\end{array}$ & $\begin{array}{c}4.26 \\
( \pm 0.78)\end{array}$ & $\begin{array}{c}9.83 \\
( \pm 0.90)\end{array}$ \\
\hline Mesostigmata & Alliphis siculus & $\begin{array}{l}\text { High trophic level } \\
\text { mesofauna }\end{array}$ & $\begin{array}{c}1.63 \\
( \pm 1.80)\end{array}$ & $\begin{array}{c}2.36 \\
( \pm 2.14)\end{array}$ & $\begin{array}{c}11.65 \\
( \pm 4.01)\end{array}$ & 1.86 \\
\hline Mesostigmata & $\begin{array}{c}\text { Hypoaspis } \\
\text { aculeifer }\end{array}$ & $\begin{array}{l}\text { High trophic level } \\
\text { mesofauna }\end{array}$ & $\begin{array}{c}0.48 \\
( \pm 1.46)\end{array}$ & $\begin{array}{c}4.35 \\
( \pm 4.07)\end{array}$ & $\begin{array}{c}28.13 \\
( \pm 2.65)\end{array}$ & \\
\hline Mesostigmata & Lysigamasus sp. & $\begin{array}{l}\text { High trophic level } \\
\text { mesofauna }\end{array}$ & $\begin{array}{c}0.00 \\
( \pm 2.59)\end{array}$ & $\begin{array}{c}6.70 \\
( \pm 3.14)\end{array}$ & & \\
\hline Mesostigmata & $\begin{array}{c}\text { Nenteria } \\
\text { breviunguiculata }\end{array}$ & $\begin{array}{l}\text { High trophic level } \\
\text { mesofauna }\end{array}$ & 0.00 & & 2.99 & \\
\hline Mesostigmata & Pergamasus sp. & $\begin{array}{l}\text { High trophic level } \\
\text { mesofauna }\end{array}$ & $\begin{array}{c}0.34 \\
( \pm 0.41)\end{array}$ & & $\begin{array}{c}4.23 \\
( \pm 1.97)\end{array}$ & 77.88 \\
\hline Symphyla & $\begin{array}{l}\text { Symphylella } \\
\text { vulgaris }\end{array}$ & $\begin{array}{l}\text { High trophic level } \\
\text { macrofauna }\end{array}$ & $\begin{array}{c}4.19 \\
( \pm 0.72)\end{array}$ & $\begin{array}{c}5.71 \\
( \pm 0.92)\end{array}$ & $\begin{array}{c}8.43 \\
( \pm 6.45)\end{array}$ & $\begin{array}{l}17.19 \\
( \pm 2.99)\end{array}$ \\
\hline Chilopoda & $\begin{array}{l}\text { Lamyctes } \\
\text { fulvicornis }\end{array}$ & $\begin{array}{l}\text { High trophic level } \\
\text { macrofauna }\end{array}$ & $\begin{array}{c}2.08 \\
( \pm 1.62)\end{array}$ & $\begin{array}{c}6.92 \\
( \pm 4.45)\end{array}$ & $\begin{array}{c}0.00 \\
( \pm 1.43)\end{array}$ & 18.54 \\
\hline Chilopoda & $\begin{array}{l}\text { Necrophloeophagus } \\
\text { longicornis }\end{array}$ & $\begin{array}{l}\text { High trophic level } \\
\text { macrofauna }\end{array}$ & & & & 2.26 \\
\hline Diplopoda & $\begin{array}{l}\text { Blaniulus } \\
\text { guttulatus }\end{array}$ & $\begin{array}{l}\text { Low trophic level } \\
\text { macrofauna }\end{array}$ & 10.78 & $\begin{array}{c}5.48 \\
( \pm 3.57)\end{array}$ & $\begin{array}{c}0.00 \\
( \pm 7.07)\end{array}$ & 44.94 \\
\hline Diplopoda & $\begin{array}{l}\text { Polydesmus } \\
\text { superus }\end{array}$ & $\begin{array}{l}\text { Low trophic level } \\
\text { macrofauna }\end{array}$ & & $\begin{array}{c}8.71 \\
( \pm 1.03)\end{array}$ & $\begin{array}{c}3.63 \\
( \pm 2.27)\end{array}$ & \\
\hline Araneae & Meioneta sp. & $\begin{array}{l}\text { High trophic level } \\
\text { macrofauna }\end{array}$ & 4.16 & $\begin{array}{c}7.35 \\
( \pm 1.54) \\
\end{array}$ & $\begin{array}{r}11.48 \\
( \pm 0.39) \\
\end{array}$ & $\begin{array}{c}3.97 \\
( \pm 5.29) \\
\end{array}$ \\
\hline Diptera & Muscidae larvae & $\begin{array}{c}\text { Low trophic level } \\
\text { macrofauna }\end{array}$ & 0.00 & & $\begin{array}{c}1.60 \\
( \pm 0.68)\end{array}$ & 1.58 \\
\hline Coleoptera & Aleocharinae & $\begin{array}{l}\text { Low trophic level } \\
\text { macrofauna }\end{array}$ & & $\begin{array}{c}7.49 \\
( \pm 5.99)\end{array}$ & 21.75 & \\
\hline Coleoptera & Elateridae larvae & $\begin{array}{l}\text { High trophic level } \\
\text { macrofauna }\end{array}$ & $\begin{array}{c}3.11 \\
( \pm 0.94)\end{array}$ & $\begin{array}{c}18.19 \\
( \pm 8.23)\end{array}$ & $\begin{array}{c}2.05 \\
( \pm 1.35)\end{array}$ & $\begin{array}{c}3.54 \\
( \pm 1.86)\end{array}$ \\
\hline Coleoptera & Paederinae & $\begin{array}{l}\text { Low trophic level } \\
\text { macrofauna }\end{array}$ & $\begin{array}{c}6.25 \\
( \pm 2.25)\end{array}$ & & 6.34 & \\
\hline Coleoptera & Scopaeus sp. & $\begin{array}{l}\text { High trophic level } \\
\text { macrofauna }\end{array}$ & & 2.15 & 2.80 & 9.89 \\
\hline Coleoptera & $\begin{array}{l}\text { Staphylinidae } \\
\text { larvae }\end{array}$ & $\begin{array}{l}\text { Low trophic level } \\
\text { macrofauna }\end{array}$ & $\begin{array}{c}0.64 \\
( \pm 4.06)\end{array}$ & & & 8.78 \\
\hline
\end{tabular}


Table S4: Incorporation of ${ }^{15} \mathrm{~N}$ into soil animal species after labeling $\left(\Delta^{15} \mathrm{~N}\right) .2 \mathrm{~d}=2$ days after labeling, $5 \mathrm{~d}=5$ days, $10 \mathrm{~d}=$ 10 days, $25 \mathrm{~d}=25$ days; $\mathrm{SEM}=$ standard error of the mean; values lacking parentheses represent single measurements.

\begin{tabular}{|c|c|c|c|c|c|c|}
\hline \multirow{2}{*}{\multicolumn{2}{|c|}{ Species }} & \multirow{2}{*}{ Trophic Group } & \multicolumn{4}{|c|}{$\Delta^{15} N( \pm S E)$} \\
\hline & & & d2 & d5 & d10 & d25 \\
\hline Collembola & $\begin{array}{c}\text { Bourletiella } \\
\text { hortensis }\end{array}$ & $\begin{array}{c}\text { Low trophic level } \\
\text { mesofauna }\end{array}$ & $\begin{array}{c}87.58 \\
( \pm 8.03)\end{array}$ & $\begin{array}{c}35.07 \\
( \pm 38.71)\end{array}$ & $\begin{array}{c}26.79 \\
( \pm 15.80)\end{array}$ & 126.77 \\
\hline Collembola & Isotoma viridis & $\begin{array}{l}\text { High trophic level } \\
\text { mesofauna }\end{array}$ & $\begin{array}{c}71.88 \\
( \pm 2.96)\end{array}$ & $\begin{array}{c}103.42 \\
( \pm 32.91)\end{array}$ & 60.79 & $\begin{array}{c}167.28 \\
( \pm 40.42)\end{array}$ \\
\hline Collembola & $\begin{array}{l}\text { Lepidocyrtus } \\
\text { cyaneus }\end{array}$ & $\begin{array}{l}\text { High trophic level } \\
\text { mesofauna }\end{array}$ & $\begin{array}{l}130.14 \\
( \pm 8.50)\end{array}$ & $\begin{array}{c}0.07 \\
( \pm 8.71)\end{array}$ & & 89.76 \\
\hline Collembola & $\begin{array}{c}\text { Protaphorura } \\
\text { armata }\end{array}$ & $\begin{array}{c}\text { Low trophic level } \\
\text { mesofauna }\end{array}$ & $\begin{array}{c}46.55 \\
( \pm 24.61)\end{array}$ & $\begin{array}{c}225.28 \\
( \pm 70.99)\end{array}$ & $\begin{array}{c}141.43 \\
( \pm 39.01)\end{array}$ & $\begin{array}{c}513.52 \\
( \pm 80.35)\end{array}$ \\
\hline Collembola & $\begin{array}{c}\text { Pseudosinella } \\
\text { alba }\end{array}$ & $\begin{array}{l}\text { High trophic level } \\
\text { mesofauna }\end{array}$ & 29.01 & $\begin{array}{c}103.80 \\
( \pm 53.44)\end{array}$ & $\begin{array}{c}264.03 \\
( \pm 50.80)\end{array}$ & \\
\hline Collembola & Willowsia buski & $\begin{array}{c}\text { High trophic level } \\
\text { mesofauna }\end{array}$ & & $\begin{array}{c}30.73 \\
( \pm 8.44) \\
\end{array}$ & 142.15 & \\
\hline Oribatida & Oppiella nova & $\begin{array}{l}\text { High trophic level } \\
\text { mesofauna }\end{array}$ & 35.28 & 83.67 & $\begin{array}{c}132.74 \\
( \pm 25.43)\end{array}$ & \\
\hline Oribatida & $\begin{array}{l}\text { Tectocepheus } \\
\text { velatus }\end{array}$ & $\begin{array}{c}\text { Low trophic level } \\
\text { mesofauna }\end{array}$ & $\begin{array}{c}10.33 \\
( \pm 0.97)\end{array}$ & $\begin{array}{c}20.40 \\
( \pm 5.32)\end{array}$ & $\begin{array}{c}18.51 \\
( \pm 6.38)\end{array}$ & $\begin{array}{c}101.47 \\
( \pm 32.89)\end{array}$ \\
\hline Mesostigmata & Alliphis siculus & $\begin{array}{l}\text { High trophic level } \\
\text { mesofauna }\end{array}$ & $\begin{array}{c}5.55 \\
( \pm 4.53)\end{array}$ & $\begin{array}{c}41.11 \\
( \pm 37.98)\end{array}$ & $\begin{array}{c}23.33 \\
( \pm 10.17)\end{array}$ & 39.34 \\
\hline Mesostigmata & $\begin{array}{l}\text { Hypoaspis } \\
\text { aculeifer }\end{array}$ & $\begin{array}{l}\text { High trophic level } \\
\text { mesofauna }\end{array}$ & $\begin{array}{c}17.04 \\
( \pm 9.29)\end{array}$ & $\begin{array}{c}48.34 \\
( \pm 7.82)\end{array}$ & $\begin{array}{c}125.34 \\
( \pm 11.69)\end{array}$ & \\
\hline Mesostigmata & Lysigamasus sp. & $\begin{array}{l}\text { High trophic level } \\
\text { mesofauna }\end{array}$ & $\begin{array}{c}7.63 \\
( \pm 5.49)\end{array}$ & $\begin{array}{c}16.91 \\
( \pm 3.08)\end{array}$ & & \\
\hline Mesostigmata & $\begin{array}{c}\text { Nenteria } \\
\text { breviunguiculata }\end{array}$ & $\begin{array}{l}\text { High trophic level } \\
\text { mesofauna }\end{array}$ & 13.43 & & 26.79 & \\
\hline Mesostigmata & Pergamasus sp. & $\begin{array}{l}\text { High trophic level } \\
\text { mesofauna }\end{array}$ & $\begin{array}{c}1.17 \\
( \pm 0.68)\end{array}$ & & $\begin{array}{c}15.86 \\
( \pm 13.18)\end{array}$ & 167.95 \\
\hline Symphyla & $\begin{array}{l}\text { Symphylella } \\
\text { vulgaris }\end{array}$ & $\begin{array}{l}\text { High trophic level } \\
\text { macrofauna }\end{array}$ & $\begin{array}{c}6.02 \\
( \pm 0.72)\end{array}$ & $\begin{array}{c}65.19 \\
( \pm 17.23)\end{array}$ & $\begin{array}{c}17.01 \\
( \pm 1.75)\end{array}$ & $\begin{array}{c}79.43 \\
( \pm 10.67)\end{array}$ \\
\hline Chilopoda & $\begin{array}{l}\text { Lamyctes } \\
\text { fulvicornis }\end{array}$ & $\begin{array}{l}\text { High trophic level } \\
\text { macrofauna }\end{array}$ & $\begin{array}{c}4.96 \\
( \pm 4.89)\end{array}$ & $\begin{array}{c}48.27 \\
( \pm 26.32)\end{array}$ & $\begin{array}{c}19.30 \\
( \pm 7.32)\end{array}$ & 72.93 \\
\hline Chilopoda & $\begin{array}{l}\text { Necrophloeophagus } \\
\text { longicornis }\end{array}$ & $\begin{array}{l}\text { High trophic level } \\
\text { macrofauna }\end{array}$ & & & & 62.40 \\
\hline Diplopoda & $\begin{array}{l}\text { Blaniulus } \\
\text { guttulatus }\end{array}$ & $\begin{array}{l}\text { Low trophic level } \\
\text { macrofauna }\end{array}$ & 0.00 & $\begin{array}{c}19.71 \\
( \pm 6.25)\end{array}$ & $\begin{array}{c}14.72 \\
( \pm 9.32)\end{array}$ & 98.02 \\
\hline Diplopoda & $\begin{array}{l}\text { Polydesmus } \\
\text { superus }\end{array}$ & $\begin{array}{c}\text { Low trophic level } \\
\text { macrofauna }\end{array}$ & & $\begin{array}{c}43.42 \\
( \pm 9.60) \\
\end{array}$ & $\begin{array}{c}3.80 \\
( \pm 6.73) \\
\end{array}$ & \\
\hline Araneae & Meioneta sp. & $\begin{array}{l}\text { High trophic level } \\
\text { macrofauna }\end{array}$ & 39.21 & $\begin{array}{c}14.15 \\
( \pm 10.07) \\
\end{array}$ & $\begin{array}{c}37.62 \\
( \pm 19.91) \\
\end{array}$ & $0.00( \pm 2.57)$ \\
\hline Diptera & Muscidae larvae & $\begin{array}{l}\text { Low trophic level } \\
\text { macrofauna }\end{array}$ & 18.83 & & $\begin{array}{c}42.57 \\
( \pm 6.88)\end{array}$ & 77.15 \\
\hline Coleoptera & Aleocharinae & $\begin{array}{c}\text { Low trophic level } \\
\text { macrofauna }\end{array}$ & & $\begin{array}{c}43.98 \\
( \pm 19.77)\end{array}$ & 169.07 & \\
\hline Coleoptera & Elateridae larvae & $\begin{array}{l}\text { High trophic level } \\
\text { macrofauna }\end{array}$ & $\begin{array}{c}0.00 \\
( \pm 1.60)\end{array}$ & $\begin{array}{c}53.50 \\
( \pm 19.96)\end{array}$ & $\begin{array}{c}10.06 \\
( \pm 7.32)\end{array}$ & $\begin{array}{c}29.75 \\
( \pm 5.48)\end{array}$ \\
\hline Coleoptera & Paederinae & $\begin{array}{l}\text { Low trophic level } \\
\text { macrofauna }\end{array}$ & $\begin{array}{c}30.63 \\
( \pm 21.46)\end{array}$ & & 57.62 & \\
\hline Coleoptera & Scopaeus sp. & $\begin{array}{l}\text { High trophic level } \\
\text { macrofauna }\end{array}$ & & 3.82 & 2.14 & 56.55 \\
\hline Coleoptera & $\begin{array}{c}\text { Staphylinidae } \\
\text { larvae }\end{array}$ & $\begin{array}{l}\text { Low trophic level } \\
\text { macrofauna }\end{array}$ & $\begin{array}{c}0.82 \\
( \pm 1.93)\end{array}$ & & & 88.35 \\
\hline
\end{tabular}


Chapter 5

\section{General Discussion}

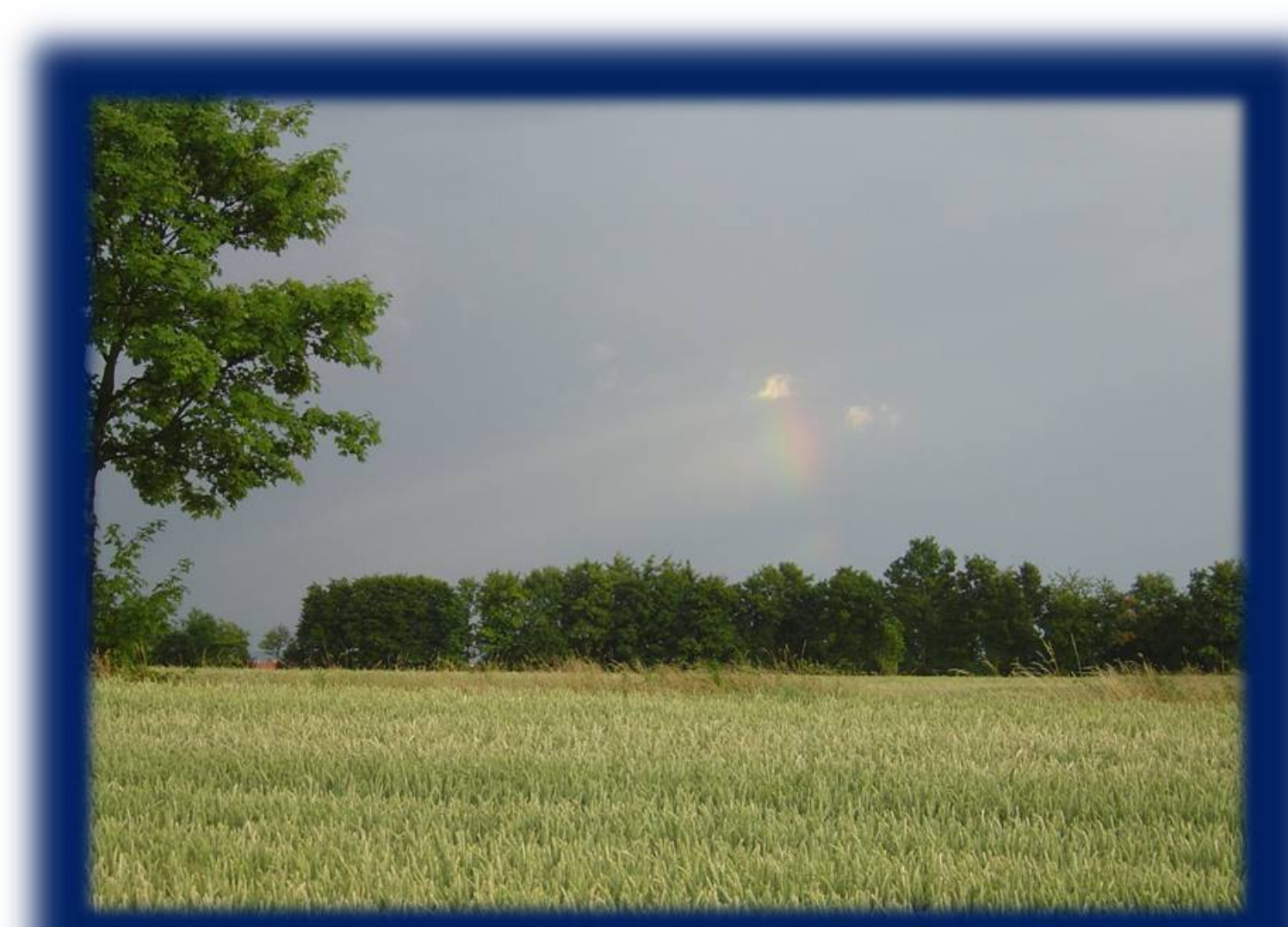


This thesis has led to major advances in the understanding of how the spatiotemporal availability of shoot residue- and root-derived resources structures soil arthropod communities and impacts energy flows through the soil food web in arable fields. Specifically, I investigated effects of shoot residue addition on the abundance and community composition of soil arthropods (Chapter 2 ) and how shoot residue- and rootderived $\mathrm{C}$ contribute to the body mass $\mathrm{C}$ of soil arthropods (Chapter 3 ). In general, I found root-derived resources to be of much higher importance for the abundance of soil arthropods and the formation of body tissue than shoot residue-derived resources. However, I discovered species specific exploitation of those basal resources, suggesting different feeding strategies within taxonomic and trophic groups of soil arthropods in arable fields. Further, my results highlighted the importance of recently assimilated rootderived C for arable soil food webs in a pulse labelling field experiment (Chapter 4). Finally, results of this experiment suggest that saprotrophic fungi occupy a central position in energy and nutrient fluxes in arable soil food webs by providing higher trophic levels simultaneously with root-derived resources and inorganic nutrients.

\section{The role of shoot residue- and root-derived C for arable soil food webs}

The results of this thesis suggest that shoot residue-derived resources are of little importance for soil arthropods in arable fields. Addition of shoot residues did not increase soil arthropod abundances in wheat and maize fields (Chapter 2), neither when applied on the soil surface and thereby increasing habitat structure (Halaj and Wise, 2002; Eissfeller et al., 2013), nor by increasing resource availability when incorporated into the soil after tillage (Chapter 3 ). Importantly, incorporation of shoot residue-derived $\mathrm{C}$ was low and averaged $15 \%$ of soil arthropod body mass, whereas root-derived resources contributed to soil arthropod body mass to an average of $34 \%$. This contrasts previous studies that found soil arthropods to incorporate high amounts of shoot residue-derived C (Elfstrand et al., 2008; von Berg et al., 2010), and may explain the poor impact of shoot residue-derived resources on soil arthropod abundances and community composition in the present study. 
Belowground resources, on the contrary, were heavily incorporated into soil arthropod body tissue and positively affected soil arthropod abundances (Chapter 2, 3). At least two basic pools of belowground resources contributed to the nutrition of soil food webs: Firstly, living roots including root tissue and exudates that were only available during the growing season. The amount of $C$ released as root exudates varies with plant developmental stage, with decreasing amounts released to the soil with progressing plant growth period (Hamlen et al., 1972). Living roots are also frequently consumed by soil arthropods (Traugott et al., 2008; Endlweber et al., 2009; Staudacher et al., 2011), with the availability increasing steadily until harvest, thereby compensating the reduced availability of root exudates (Keith et al., 1986). Overall, C derived from root exudates and living root tissue contributed more than $30 \%$ to body $\mathrm{C}$ of soil arthropods in the long term (Chapter 3), highlighting their importance for arable soil food webs.

Secondly, while root exudates and living root material are available during the growing season, root residues presumably serve as basal resource for soil arthropods in fallow periods. Increasing soil arthropod abundance in wheat fields after harvest most likely was related to the presence of wheat root residues (Chapter 2). Although maize and wheat roots are of similar nutritional quality, soil arthropods may have benefitted from the higher proportion of fine roots in wheat fields (Dornbush et al., 2002). In maize fields, in contrast, low abundances of soil arthropods in winter indicated low nutritional quality of maize root residues due to the high proportion of coarse roots. Supporting this hypothesis, a litterbag study at the field site including a mixture of fine and coarse maize roots indicated mass loss within 12 months being less than 50\% (N. Scheunemann, unpublished data).

Apart from being directly consumed by soil arthropods, plant $C$ enters higher trophic levels also via a large number of soil microorganisms. It is widely assumed that saprotrophic fungi predominantly rely on aboveground shoot residue-derived resources while soil bacteria, in contrast, predominantly rely on belowground root-derived resources (Ruess and Ferris, 2004). The lower incorporation of shoot residue-derived than root-derived resources into soil arthropods in the present study suggests that the majority of $C$ is channeled via the bacterial energy channel in arable soils (Chapter 3 ), as suggested earlier by Ngosong et al. (2009). However, investigation of microbial 
phospholipid fatty acids during the labelling experiment revealed a central position of saprotrophic fungi in cycling of root-derived $C$ in the studied maize field (Chapter 4). Consequently, the relevance of saprotrophic fungi for cycling of $C$ in soil food webs is not restricted to decomposition of shoot residue-derived resources. This is in line with recent studies that highlight the role of saprotrophic soil fungi in utilizing easily available $\mathrm{C}$ resources like root exudates in grassland (Lemanski and Scheu, 2014) and arable soils (Tavi et al., 2013), suggesting that the compartmentalization of energy channels in soil food webs is less strict than previously assumed.

\section{Feeding strategies of trophic and taxonomic groups and individual species}

Separation of soil arthropods into trophic groups or identification at low taxonomic resolution is a frequently used method to simplify and fasten the time-consuming identification process when investigating soil food webs. In the present thesis I adopted a species-specific approach to analyze the utilization of basal resources and therefore was able to compare species specific feeding strategies with general patterns found for trophic and taxonomic groups (Chapter 2,3). I found that the preferences in resource utilization of trophic and taxonomic groups are reflecting main $C$ fluxes to a certain degree. But in addition, I found large differences in resource utilization between species irrespective of trophic or taxonomic group affiliation suggesting that identification of trophic links at species level is needed to disentangle energy and nutrient fluxes in arable soil food webs in detail.

For instance, the abundance of Gamasida was positively affected by shoot residue addition, but this was only true for the most abundant species Alliphis siculus, whereas the eight remaining Gamasida taxa did not respond significantly to litter addition (Chapter 2). Furthermore, root-derived resources generally outweighed shoot residue-derived resources in fuelling soil food webs by a factor of about two. At higher taxonomic resolution, however, incorporation of shoot residue- and root-derived resources varied between species, independent of trophic or taxonomic group affiliation. About $50 \%$ of the taxa showed incorporation of both shoot residue- and root-derived $C$ at a 1:2 ratio, while $30 \%$ of the taxa strongly preferred root-derived over shoot residue-derived resources, 
$10 \%$ relied primarily on shoot residues, and another $10 \%$ incorporated neither shoot residue- nor root-derived maize C (Chapter 3). Similarly, the generally increasing incorporation of root-derived resources with time did not differ between trophic groups of soil arthropods, but rather independent of trophic group affiliation I found three patterns including increasing, decreasing and constant incorporation with time at higher taxonomic resolution (Chapter 3).

Shoot residue- and root-derived $C$ is channeled to higher trophic levels of soil arthropods via several trophic steps. In particular plant feeding and fungivorous nematodes serve as valuable prey for soil arthropods (Koehler, 1997; Klarner et al., 2013), presumably because nematode densities in arable fields are high, reaching up to 15 individuals $\mathrm{g}^{-1}$ soil (Yeates, 1999; Scharroba et al., 2012). Addition of shoot residues increased nematode abundances in July 2010 (Scharroba et al., 2012), followed by increasing abundance of $A$. siculus, a well-known nematode feeder (Chapter 2). The abundance of Collembola also slightly increased after shoot residues had been incorporated into the soil in July 2010, suggesting that Collembola also benefitted from nematodes as high energetic food source. Recent research indeed suggest that a high number of soil arthropod taxa is feeding on nematodes (Read et al., 2006; Heidemann et al., 2014), including Oribatida and Collembola that were formerly assumed to be fungal feeders (Rusek, 1998). Further, the majority of Collembola species were classified as predators due to high ${ }^{15} \mathrm{~N}$ signatures (Chapter 3 ). This supports the assumption of at least occasional feeding on nematodes in many species of Collembola and suggests that nematophagy is a common feeding strategy in arable soil food webs that is not restricted to typical predators but also includes omnivores such as many Collembola species.

\section{Habitat conditions in maize and wheat fields}

Abundances and diversity of soil arthropods were much higher in wheat than maize fields (Chapter 2), supporting earlier findings (Scheunemann et al., 2010). Higher resource quality and availability most likely was the main reason for the beneficial effect of wheat on soil arthropod abundances. Firstly, the more branched and spatially extended root system of wheat as compared to maize provided soil arthropods with more resources in 
form of living and dead roots (Endlweber et al., 2009). Further, larger amounts of root exudates released to the soil by wheat plants (Kramer et al., 2013) presumably beneficially affected the soil microbial community and, via trophic links, higher trophic levels of soil arthropods. Secondly, the more complex habitat structure in wheat due to higher plant density improved micro-environmental conditions by increasing shade and, as a result, soil moisture (Kramer et al., 2013).

Apart from general differences in soil arthropod abundance between maize and wheat fields, I observed large seasonal variability in soil arthropod abundance and community composition in wheat, but not in maize fields. In wheat fields abundances of most taxonomic groups increased after harvest indicating that in wheat fields more pronounced pulses of resources entered the soil community (Chapter 2). Most likely dead roots that remained in soil after harvest served as main basal resource during the fallow period, with the higher nutritional quality of wheat roots enhancing soil arthropod abundances. Further, winter wheat seedlings that originated from grains lost during harvest appeared at the wheat field in late autumn and may have released small amounts of $C$ in form of root exudates to the soil that were incorporated into the soil food web. Nonetheless, due to low temperatures and the low number of plant seedlings root exudates most likely played a minor role in the nutrition of soil arthropods during winter, pointing to decaying wheat roots as main resources during the fallow period (Hamlen et al., 1972).

In maize fields, in contrast, low abundance of soil arthropods at each of the sampling dates reflected that environmental conditions and resource supply varied little with crop coverage and season (Chapter 2). Presumably, this resulted from relatively low release of root exudates by maize plants in summer (Scharroba et al., 2012; Kramer et al., 2013), and the low decomposability of maize root residues during fallow periods (see above). Notably, the addition of aboveground resources in form of maize shoot residues was insufficient to counteract the low resource availability in maize fields in winter, supporting the assumption that arable soil food webs are limited by belowground rather than aboveground resources. 


\section{Conclusion}

Arable soil food webs are driven by belowground resources with living root tissue and root exudates as basal resources during plant growth and decaying root residues during the fallow period. Aboveground resources, in contrast, have only limited effect on higher trophic levels of the soil food web, i.e. meso- and macrofauna decomposers and predators. In consequence, the strong beneficial effect of wheat as compared to maize plants on soil arthropod performance results from providing belowground resources, and outweighs availability of aboveground resources in affecting soil arthropod performance. Nonetheless, utilization of basal resources is species-specific with trophic and taxonomic groups reflecting effects of above- and belowground resources only to a limited extent.

\section{Outlook}

Energy fluxes within basal trophic levels of the soil food web critically affect resource availability for soil arthropods. Therefore, a broad holistic approach investigating all trophic levels of the soil food web is required to understand energy and nutrient fluxes in soil food webs in detail. Stable isotope analysis provides insight into $C$ and nutrient fluxes in soil food webs and is time and cost efficient, however, more elaborate methods may further increase our understanding of these processes. Compound-specific analysis of stable isotope ratios in neutral lipid fatty acids or amino acids of soil arthropods may help to refine our understanding of $\mathrm{C}$ and $\mathrm{N}$ fluxes in soil food webs. For instance, distinction between different basal resources of root-derived C, i.e. root tissue and root exudates, can be achieved by analysis of neutral lipids in consumers, thereby allowing differentiation between true herbivores and microbivores that rely on root $\mathrm{C}$.

Investigation of the soil food web is often hampered by the small body mass of the species of the soil food web. Although stable isotope analysis methods have become more sensitive in recent years, knowledge on trophic links between the microbial and arthropod food web is scarce. Protists and nematodes are of small body size but play a crucial role as they link the microbial and arthropod food web by predation on soil microorganisms inducing resource competition with, but also serving as prey for 
mesofauna species. A promising tool for investigating these interactions is molecular gut content analysis which recently has been applied for investigating trophic interactions between nematodes and mesofauna in the laboratory as well as in the field. The advantage of molecular gut content analysis compared to stable isotope analysis is that it provides detailed snap-shot views at the level of genera or species into the nutrition of predators, while the analysis of stable isotopes gives a more general overview on the trophic position of species.

Combining stable isotope labelling with analysis of fatty acids and amino acids, and molecular gut content analysis may enhance our understanding of trophic relationships in soil food webs and help to predict the impact of climate change on arable as well as forest and grassland ecosystems.

\section{References}

Dornbush, M.E., Isenhart, T.M., Raich, J.W., 2002. Quantifying fine-root decomposition: An alternative to buried litterbags. Ecology 83, 2985-2990.

Eissfeller, V., Langenbruch, C., Jacob, A., Maraun, M., Scheu, S., 2013. Tree identity surpasses tree diversity in affecting the community structure of oribatid mites (Oribatida) of deciduous temperate forests. Soil Biology \& Biochemistry 63, 154-162.

Elfstrand, S., Lagerlöf, J., Hedlund, K., Mårtensson, A., 2008. Carbon routes from decomposing plant residues and living roots into soil food webs assessed with ${ }^{13} \mathrm{C}$ labelling. Soil Biology \& Biochemistry 40, 2530-2539.

Endlweber, K., Ruess, L., Scheu, S., 2009. Collembola switch diet in presence of plant roots thereby functioning as herbivores. Soil Biology \& Biochemistry 41, 1151-1154.

Halaj, J., Wise, D.H., 2002. Impact of a detrital subsidy on trophic cascades in a terrestrial grazing food web. Ecology 83, 3141-3151.

Hamlen, R.A., Lukezic, F.L., Bloom, J.R., 1972. Influence of age and stage of development on the neutral carbohydrate components in root exudates from alfalfa plants grown in a gnotobiotic environment. Canadian Journal of Plant Science 52, 633-642. 
Heidemann, K., Hennies, A., Schakowske, J., Blumenberg, L., Ruess, L., Scheu, S., Maraun, M., 2014. Free-living nematodes as prey for higher trophic levels of forest soil food webs. Oikos 123, 1199-1211.

Keith, H., Oades, J., Martin, J., 1986. Input of carbon to soil from wheat plants. Soil Biology \& Biochemistry 18, 445-449.

Klarner, B., Maraun, M., Scheu, S., 2013. Trophic diversity and niche partitioning in a species rich predator guild - Natural variations in stable isotope ratios $\left({ }^{13} \mathrm{C} /{ }^{12} \mathrm{C}\right.$, ${ }^{15} \mathrm{~N} /{ }^{14} \mathrm{~N}$ ) of mesostigmatid mites (Acari, Mesostigmata) from Central European beech forests. Soil Biology \& Biochemistry 57, 327-333.

Koehler, H.H., 1997. Mesostigmata (Gamasina, Uropodina), efficient predators in agroecosystems. Agriculture, Ecosystems \& Environment 62, 105-117.

Kramer, S., Marhan, S., Haslwimmer, H., Ruess, L., Kandeler, E., 2013. Temporal variation in surface and subsoil abundance and function of the soil microbial community in an arable soil. Soil Biology \& Biochemistry 61, 76-85.

Lemanski, K., Scheu, S., 2014. Incorporation of ${ }^{13} \mathrm{C}$ labelled glucose into soil microorganisms of grassland: Effects of fertilizer addition and plant functional group composition. Soil Biology \& Biochemistry 69, 38-45.

Ngosong, C., Raupp, J., Scheu, S., Ruess, L., 2009. Low importance for a fungal based food web in arable soils under mineral and organic fertilization indicated by Collembola grazers. Soil Biology \& Biochemistry 41, 2308-2317.

Read, D.S., Sheppard, S.K., Bruford, M.W., Glen, D.M., Symondson, W.O.C., 2006. Molecular detection of predation by soil micro-arthropods on nematodes. Molecular Ecology 15, 1963-1972.

Ruess, L., Ferris, H., 2004. Decomposition pathways and successional changes. Nematology Monographs \& Perspectives 2, 547-556.

Rusek, J., 1998. Biodiversity of Collembola and their functional role in the ecosystem. Biodiversity and Conservation 7, 1207-1219.

Scharroba, A., Dibbern, D., Hünninghaus, M., Kramer, S., Moll, J., Butenschoen, O., Bonkowski, M., Buscot, F., Kandeler, E., Koller, R., Krüger, D., Lueders, T., Scheu, S., Ruess, L., 2012. Effects of resource availability and quality on the structure of the micro-food web of an arable soil across depth. Soil Biology \& Biochemistry 50, 1-11. 
Scheunemann, N., Scheu, S., Butenschoen, O., 2010. Incorporation of decade old soil carbon into the soil animal food web of an arable system. Applied Soil Ecology 46, 59-63.

Staudacher, K., Wallinger, C., Schallhart, N., Traugott, M., 2011. Detecting ingested plant DNA in soil-living insect larvae. Soil Biology \& Biochemistry 43, 346-350.

Tavi, N.M., Martikainen, P.J., Lokko, K., Kontro, M., Wild, B., Richter, A., Biasi, C., 2013. Linking microbial community structure and allocation of plant-derived carbon in an organic agricultural soil using ${ }^{13} \mathrm{CO}_{2}$ pulse-chase labelling combined with ${ }^{13} \mathrm{C}$-PLFA profiling. Soil Biology \& Biochemistry 58, 207-215.

Traugott, M., Schallhart, N., Kaufmann, R., Juen, A., 2008. The feeding ecology of elaterid larvae in central European arable land: New perspectives based on naturally occurring stable isotopes. Soil Biology \& Biochemistry 40, 342-349.

Von Berg, K., Thies, C., Tscharntke, T., Scheu, S., 2010. Changes in herbivore control in arable fields by detrital subsidies depend on predator species and vary in space. Oecologia 163, 1033-1042.

Yeates, G.W., 1999. Effects of plants on nematode community structure. Annual Review of Phytopathology 37, 127-149. 


\section{Acknowledgements}

Als erstes möchte ich Stefan Scheu danken für die Möglichkeit, Teil der Arbeitsgruppe sein zu und wissenschaftlich arbeiten zu dürfen. Vielen Dank für deine Unterstützung und die unglaublichen Mengen an Fachwissen und Enthusiasmus, die meine Arbeit sehr bereichert haben. Danke für dein offenes Ohr und deine kompetente Hilfe bei allen Fragen und den Glauben an mich und mein Projekt.

Ein genauso großer Dank geht an Olaf Butenschön, der seit Beginn meiner Arbeit in der AG Scheu mein Betreuer war und der maßgeblich nicht nur zu dieser Dissertation beigetragen hat, sondern für mich immer ein großes Vorbild an Effizienz und wissenschaftlichem Arbeiten war. Danke, dass du meine Manuskripte von den ersten holprigen Versuchen an mit großer Geduld gelesen und verbessert hast, auch nachdem du Göttingen eigentlich schon den Rücken gekehrt hattest. Danke auch für deine organisatorische Arbeit im Projekt, die das Holtenser Maisfeld am Leben gehalten hat.

Vielen Dank an die Forschergruppe FOR 918 für die gute Zusammenarbeit, vor allem an die Doktorandinnen der ersten Projektphase: Johanna Pausch, Anika Scharroba, Susanne Kramer, Julia Moll, Birgit Lang, Dörte Dibbern und Maike Hünninghaus; plus Andreas Schmalwasser. Weiterhin danke ich Sebastian Löppmann und Menuka Maharjan für die Mitarbeit in späteren Projekten, sowie Andreas Richter und Liliane Ruess für die geduldige Beantwortung meiner Fragen diesbezüglich.

Weiterhin möchte ich meinem Prüfungskomitee, bestehend aus Stefan Scheu, Uli Brose und Liliane Ruess für die eine oder andere Verlängerung meiner Studienzeit danken.

Vielen Dank an Mark Maraun und Christoph Digel für ihre Hilfe bei der statistischen Auswertung meiner Datensätze.

Danke an Christel Fischer, Andrea Lambertz, Dieter Nünchert, Susanne Böning-Klein, Ingrid Kleinhans und Guido Humpert, die als gute Geister der AG tätig sind und unmögliche Dinge möglich machen.

Danke an Reinhard Langel vom KOSI für die Analyse meiner Proben. 
Ein liebes Dankeschön geht an alle, die mich bei der Feldarbeit unterstützt haben durch Kempson-Hämmern, Maisernten und/oder Streuverteilen. Es sind so viele (eigentlich die ganze AG Scheu, die Forschergruppe und unzählige Hiwis), deshalb hier die, die mir als erstes einfallen, allen anderen danke ich aber in gleichem Maße: Martin Rosenberger, Nils Peter, Andreas Klein, Patrick Pachl, Garvin Schulz, Diana Grubert, Kerstin Heidemann, Tanja Strecker, Guido Humpert, Kathleen Lemanski, Helge von Salzwedel, Britta Merkel, Marcel Graf,...

Vielen Dank an die gesamte AG Scheu für die gute Zusammenarbeit und die angenehme Atmosphäre. Mein ganz besonderer Dank gilt dabei den Mitgliedern der Mittags- und Kaffeerunde: Garvin Schulz, Patrick Pachl, Diana Grubert, Kerstin Heidemann, außerdem Tanja Strecker, Berhard Klarner und Vreni Eißfeller. Vielen Dank für alle lieben Worte, alle Ablenkung und die sukzessive Steigerung meines Kaffeekonsums. Eure Freundschaft bedeutet mir sehr viel!

Ich möchte mich auch ganz herzlich bei Sarah Zieger bedanken für die hilfreichen Gespräche und Tipps zur Benutzung diverser Computerprogramme, in Abwechslung mit einer ruhigen Atmosphäre, die es mir ermöglichte konzentriert zu schreiben. Sarah, du warst die beste Büromitbewohnerin, die ich mir wünschen konnte.

Vielen Dank an Freunde von weither, die ich schon seit vielen Jahren kenne: Nathalie Kaffenberger, Linda Freund und Natascha Beilstein.

Zum Schluss geht noch ein großer Dank an meine Eltern und an meine Brüder Marco und Christoph, die immer an mich glaubten und mich unterstützten, und an Kai Oliver Schneider, der mich und meine Zickereien tapfer ertragen hat. 


\section{List of publications}

\section{Published in peer-reviewed journals}

Scheunemann, N., Digel, C., Scheu, S., Butenschoen, O., 2015. Roots rather than shoot residues drive soil arthropod communities of arable fields. Oecologia 179, 11351145.

Scheunemann, N., Maraun, M., Scheu, S., Butenschoen, O., 2015. The role of shoot residues vs. crop species for soil arthropod diversity and abundance of arable systems. Soil Biology \& Biochemistry $81,81-88$.

Scheunemann, N., Scheu, S., Butenschoen, O., 2010. Incorporation of decade old soil carbon into the soil animal food web of an arable system. Applied Soil Ecology, 46, 59-63.

Pausch, J., Kramer, S., Scharroba, A., Scheunemann, N., Butenschoen, O., Kandeler, E., Marhan, S., Riederer, M., Scheu, S., Kuzyakov, Y., Ruess, L., 2015. Small but active pool size does not matter for carbon incorporation in below-ground food webs. Functional Ecology, available online.

Kramer, S., Marhan, S., Ruess, L., Armbruster, W., Butenschoen, O., Haslwimmer, H., Kuzyakov, Y., Pausch, J., Scheunemann, N., Schoene, J., Schmalwasser, A., Totsche, K.U., Walker, F., Scheu, S., Kandeler, E., 2012. Carbon flow into microbial and fungal biomass as a basis for the belowground food web of agroecosystems. Pedobiologia $55,111-119$.

Müller, K., Kramer, S., Haslwimmer, H., Marhan, S., Scheunemann, N., Butenschoen, O., Scheu, S., Kandeler, E., 2016. Carbon transfer from maize roots and litter into bacteria and fungi depends on soil depth and time. Soil Biology \& Biochemistry, accepted. 


\section{Under review}

Scheunemann, N., Pausch, J., Digel, C., Kramer, S., Scharroba, A., Kuzyakov, Y., Ruess, L., Kandeler, E., Butenschoen, O., \& Scheu, S. Incorporation of root C and fertilizer N into the soil animal food web of an arable system: Variations with taxonomic and trophic position. 


\section{Thesis declarations}

\section{Declaration of the author's own contribution to manuscripts with multiple authors}

Chapters 2 and 3 have been published in a peer-reviewed journal; I have collected all data. Chapter 4 is currently submitted to a peer-reviewed journal and is based on a dataset that was compiled by Johanna Pausch, Susanne Kramer, Anika Scharroba, Stephanie Wolf and me. Johanna Pausch supervised the experimental setup and provided stable isotope data on plant material and bulk soil, Susanne Kramer provided stable isotope data on microbial PLFAs and Anika Scharroba on nematodes. As part of this experiment Stephanie Wolf performed her Bachelor thesis that was supervised by me. She identified and analyzed stable isotope ratios of the fauna collected at two of the sampling dates. I collected the stable isotope data of the fauna of the remaining sampling dates and did the statistical analyses of all data.

I am the first author of all manuscripts; I have analyzed the data, written the manuscripts, developed the main ideas, created tables, figures and appendices and contributed significantly to the study design. The study design of each study was developed in the framework of the Research Unit "Carbon flow in belowground food webs assessed by isotope tracers" (FOR 918). All persons contributing to the manuscripts have been named so. All co-authors contributed to finalizing the manuscripts.

The cover-photographs of all Chapters are shared ownership of the FOR 918. 


\section{Plagiarism declaration}

I, Nicole Scheunemann, declare that I have written this doctoral thesis independently. All persons contributing to the manuscripts have been named so. All sentences or passages quoted from other people's work have been specifically acknowledged by clear crossreferencing.

I have not submitted this thesis in any form for another degree at any university or institution.

Nicole Scheunemann

Göttingen, February 2015 